KENNETH N. KUTT TER

Federal Reserve Bank of New York

ADAM S. POSEN

Institute for International Economics

\title{
The Great Recession: Lessons for Macroeconomic Policy from Japan
}

SiNCE THE PERSISTENCE OF Japan's economic stagnation first became apparent, the Japanese government has been offered a flood of advice from macroeconomic policy analysis. Much of this advice emanated from the official sector, most prominently from the U.S. Treasury and the International Monetary Fund (IMF), but a host of academics were likewise generous in their recommendations. ${ }^{1}$ Yet both the degree to which Japan has followed this advice and the effects of the macroeconomic policies undertaken remain in dispute. Economic commentators and other observers of Japan have split over whether standard Keynesian policies were tried and failed, whether the policies implemented had the expected effects but were offset by other factors, or whether some of the recommended policies (monetary expansion, in particular) never were seriously tried at all.

We are grateful to numerous officials and experts on the Japanese economy who helped us to acquire (and comprehend) the necessary data for this paper. They include Arthur Alexander, Timothy Callen, Charles Horioka, Toshiki Jinushi, Richard Katz, Yasuhiro Kawaguchi, Jun Kurihara, Martin Mühleisen, Seiya Nakajima, Hideki Onodera, Kenya Ozawa, Yoshinori Shimizu, Hitoshi Shimura, Andrew Smithers, Tetsuro Sugiura, Joseph Thomas, Iichiro Uesugi, Tadashi Uhira, and Tadao Yanase. We owe a special debt to Barry Bosworth, Fumio Hayashi, Takeo Hoshi, Richard Jerram, Mitsuhiro Matsuoka, and Tsutomo Watanabe for their time and generosity in giving advice. Debayani Kar provided excellent research assistance. The views expressed here and any remaining errors are solely those of the authors, and not necessarily those of the Federal Reserve Bank of New York, the Federal Reserve System, or the Institute for International Economics.

1. For statements by policymakers, among many examples, see Summers (1998) and Fischer (1998). Academic and other commentators are cited throughout the paper. 
After the longest period of below-potential growth for any developed economy since World War II-what we and others have termed the Great Recession-with no end in sight, it is worth asking what lessons there are for macroeconomic policy from Japan. Japan's experience since the burst of its stock market bubble in December 1989 constitutes a critical experiment for the effectiveness of macroeconomic policy on several grounds. First and foremost, Japan's unprecedentedly persistent shortfall of demand raises the obvious question of whether countercyclical policies had any beneficial effects, if such policies were implemented and Japan has not yet recovered. Second, the argument has often been made, although not by macroeconomists, that the Japanese economic system is somehow special, not subject to the same rules and economic logic as Western economies; if largely the same macroeconomic policy prescriptions are to be offered universally, whether or not they work in Japan is an important test case. Third, the unvarying nature of Japan's institutional structures (a topic of much criticism from advocates of structural reform) provides a unique opportunity to assess the impact of monetary and fiscal policies in the absence of other major changes in the economic environment.

On more specific issues there are also questions of real concern. As has often been observed, monetary policy in Japan today confronts a disabled banking system, the zero bound on nominal interest rates, and arguably a liquidity trap, forcing us to reexamine the efficacy of the quantity channels of monetary policy transmission. As for fiscal policy, Japan in the last decade can be seen as a case in which fiscal stimulus should have been either very effective or largely ineffective: effective because of the relatively closed economy, the reluctance of savers to move money abroad, and the vast quantities of private household savings available; ineffective because of the wastefulness of public works projects, the looming demographic threat posed by an aging population, and the rapid and obvious rise in public debt. Thus Japan represents a crucial test of the Ricardian versus the Keynesian approach to fiscal policy. Finally, that same disabled banking system, which has now limped along for a decade without resolution of its bad loans, allows us to consider the nonmonetary effects of financial fragility on the real economy when banks are not allowed to fail outright.

Thus the purpose of this paper is to establish the record and assess empirically the effects of macroeconomic policies undertaken in Japan in 
response to the Great Recession. Discussions of Japan's macroeconomic policies have all too often suffered from lack of empirical rigor. Some have been based on simplistic, uncontrolled analyses, observing, for example, that the economy has faltered despite growing fiscal deficits, and concluding from this that fiscal stimulus has failed. Others have relied on comparisons with other countries' experiences, for example in discussing what a central bank might do if faced with a liquidity trap, or simply appealed to abstract (and untested) economic principles. Very little empirical research has looked both directly and rigorously at what policies Japan has undertaken, with what effect, and what this experience implies for the efficacy of policy. We attempt to fill this void by applying modern but off-theshelf empirical techniques (developed using U.S. data) to assess the impact of macroeconomic policy in Japan in the 1990s.

We begin by characterizing the depth and breadth of the Japanese Great Recession, in terms of the basic measures of output, potential output, and inflation; the resulting picture confirms its demand-side origin. We then look at the record of monetary policy and its impact on prices and exchange rates over the period, and from this experience we glean some lessons as to the efficacy of various channels of monetary transmission in extremis. We go on to examine the role of fiscal policy, both by estimating the direct impact of spending and taxes on GDP, and by assessing the degree of Ricardian offset in the response of saving. Next we describe the breakdown of the Japanese financial system after the partial deregulation of the mid-1980s, and we examine the nonmonetary impact of financial distress. We conclude by summarizing the lessons for macroeconomic policy that we draw from the Japanese experience.

Our conclusions may be largely unsurprising to the core audience of this journal, but they may come as something of a surprise to more casual observers of the Japanese economic situation: despite the persistent stagnation, and despite the seeming ineffectiveness of several well-publicized announcements of policy changes (which proved to be more noise than action), the Japanese economy has behaved much as the textbooks would have predicted. The evidence marshaled in this paper shows that money has indeed retained its traditional role as an anchor for prices, although the banking system's distress has weakened the potency of monetary policy. The lack of any sustained increase in high-powered money in Japan to date makes it difficult to assess empirically the likely effects of aggressive open 
market operations, but also indicates that such operations are very unlikely to cause rapid inflation. Fiscal stimulus, whether in the form of tax cuts or of public works spending, is stimulative, although in Japan, tax cuts gave a bigger bang for the yen than did public works spending. Ricardian effects are perhaps in evidence but not large enough to neutralize the effects of fiscal policy even in an aging society with rapidly rising public debt. Banks' lending behavior is heavily influenced by the strength of their balance sheets (as proxied by the value of their real estate collateral or stock prices), and this has had a substantial macroeconomic impact. Market discipline is always present, whatever the stance of bank supervisors, and therefore keeping fragile or insolvent banks open does not markedly alleviate credit problems. In short, the basic lesson of Japan's Great Recession for policymakers is to trust what you learned in intermediate macroeconomics class: even under difficult economic circumstances, and even in institutional contexts far removed from those in which they were developed, the stabilization policy framework of the mainstream textbooks still applies.

\section{Characterizing the Japanese Recession}

Ultimately, the nature of Japan's Great Recession is an empirical question. In some sense, if demand management policies can be demonstrated to have had their expected effects, ceteris paribus, it would make by implication the case that a demand shortfall underlies Japan's economic performance in the 1990s. Macroeconomic policymakers, however, do need to know whether they can trust their eyes that what looks like a recession, and feels like a recession, is indeed a recession. Definitions of recession differ, of course, ranging from the standard rule of thumb of two consecutive quarters of falling GDP to the observation by the National Bureau of Economic Research of "a significant decline in activity spread across the economy, lasting more than a few months, visible in industrial production, employment, real income and wholesale-retail trade."2 We prefer to think of a recession in terms of a sustained (multiquarter) shortfall of an economy's actual growth rate from its potential, because this follows

2. Business Cycle Dating Committee, "The NBER's Recession Dating Procedure," National Bureau of Economic Research, Cambridge, Mass., November 9, 2001, p. 1. 
the standard economic principle of assessing situations by their opportunity costs. ${ }^{3}$

By just about any measure, Japan's economy has fallen far short of its potential over the past decade. ${ }^{4}$ Figure 1 plots three measures of the difference between potential and actual real GDP (the output gap). The first is based on the latent-variable statistical methodology developed by Kuttner and applied to Japan by Posen. ${ }^{5}$ Essential to this procedure are the assumptions that potential output evolves smoothly over time and that actual GDP eventually reverts to potential; the model also incorporates the behavior of inflation as a gauge of the output gap. The second estimate, that of the Organization for Economic Cooperation and Development (OECD), is based on a production function methodology, combined with an assumption about the nonaccelerating-wage rate of unemployment. ${ }^{6}$ According to both estimates, Japan's economy has been underperforming since the early 1990s and is currently operating about 3 to 4 percent below potential.

Worse still, there is good reason to believe that both the latent-variable and the OECD methods understate the true shortfall. The potential growth rate of an economy is not something that can be directly observed, of course, and the assumptions on which both methods instead depend heavily are questionable in the Japanese case. In the case of the latent-variable model, the statistical assumption of mean reversion means that, somewhat mechanically, any prolonged string of below-potential growth leads to a downward shift in the estimate of potential. Moreover, using inflation to gauge the output gap can be misleading in conditions of deflation, where the nonlinearities created by price and wage stickiness presumably become more severe.

3. Recently The Economist made a similar call: "A more sensible definition of recession might therefore be when the growth rate falls significantly (perhaps by at least two percentage points) below its long-term potential, causing unemployment to rise." "Economics Focus: Defining a Downturn," The Economist, August 4, 2001, p. 62.

4. We do not address here the severe problems with the construction of Japanese national accounts data, which have become all too apparent in recent years, as we have no alternative to using the reported GDP and its components. However, some simple stock and flow relationships in the reported Japanese data do not hold; see Ando (2000) and Jerram (2000) for details; see also Mikihiro Matsuoka, "Revision of Consumer Price Index Benchmark Year: Impact on Inflation," Deutsche Bank Group Global Markets Research: Japan, Tokyo, 2001. Both Koichi Hamada, currently head of the Economic Planning Agency's research activities, and the NBER Japan Project are making efforts to address these issues.

5. Kuttner (1994); Posen (1998).

6. For details see Giorno and others (1995a, 1995b). 
Figure 1. Estimated Gap between Potential and Actual GDP, 1976-2001

Percent of potential GDP

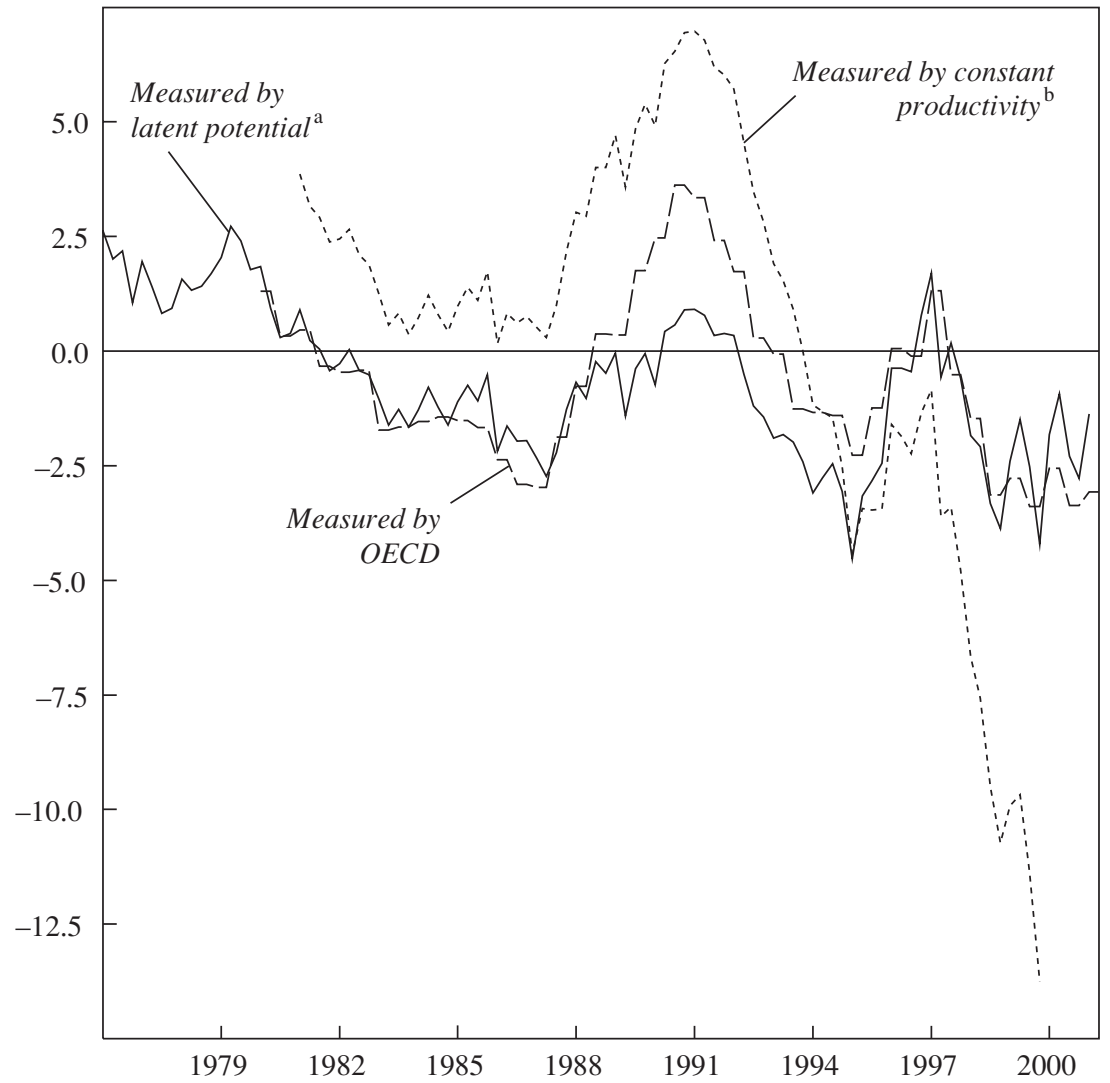

Sources: OECD and authors' calculations based on data from the Economic and Social Research Institute and the International Monetary Fund (IMF).

a. See the appendix to Posen (1998) for details.

b. Assumes that productivity grows 2.5 percent a year.

The OECD's bottom-up method also probably provides too bleak an assessment of potential output and therefore likewise understates the output gap. Unlike the purely statistical methods, these estimates require strong assumptions about the future growth of factor inputs and the returns to those inputs, both of which are endogenous. Analysts using these methods have tended to project a decline in labor supply in Japan (instead of allowing for rising retirement ages or increased entry of women into the 
work force) and have assumed an excess of capital in Japan (rather than noting that the new capital investment, in information and telecommunications technologies, for example, is both better than and different from earlier vintages of capital). They have also generally assumed that the returns to capital and labor will largely remain the same as a function of their respective stocks, their marginal products rising only in line with reductions in these stocks.

As a comparison, and to underscore the impact of these assumptions, figure 1 also plots an estimate of the output gap derived from a third measure of potential, based on observed labor force growth and an extrapolation of the previous decade's trend in labor productivity. Had productivity merely continued to grow at its 1980-92 rate of 2.5 percent a year, potential output would have far outstripped both the latent-variable and the OECD estimates, and the output gap would have grown from zero (by assumption) in 1993 to 11 percent in $1999 .{ }^{7}$ Even with annual productivity growth of only 1.5 percent, the gap would have reached nearly 8 percent by the end of 1999. Clearly, if these productivity trends and labor force assumptions are realistic, the depth of Japan's recession is far worse than indicated by the latent-variable and OECD output gap measures.

It is also striking to put Japan's economic performance in a comparative context. The OECD estimates potential output series for all its member countries on a semiannual basis using the bottom-up method described above. (We use the OECD calculations for comparison because it is infeasible to reestimate the latent-variable method, or make reasonable ad hoc adjustments, for all countries.) Whatever this method's limitations, there is no reason to believe it is more biased for any one country than another. By the OECD's account, Japan has had seventeen below-potential halfyears since 1980, fourteen of them since the first half of 1992, and seven out of a possible nine since the first half of 1997. The next-worst country in terms of below-potential performance is Germany, with eight half-years below potential since 1980 , and no more than two of those in a row. ${ }^{8}$ No

7. We are grateful to George Perry and Christopher Nekarda for suggesting these calculations.

8. We leave for future consideration the difficulties presented by a potential output measure with Lake Wobegon qualities: all the OECD countries except Japan have grown faster than potential far more than 50 percent of the time over the last twenty years. But as a comparative benchmark, at least, this measure should be unbiased. 
other country in the OECD has suffered such a lengthy period of unremittingly below-potential growth, or even one half so long and deep.

The Japanese recession has been accompanied by the first sustained deflation, in an industrial country at least, during the postwar era, although nowhere near the magnitude of that experienced in the United States during the Great Depression. The top panel in figure 2 shows four-quarter inflation rates for Japan, computed from the GDP deflator and the wholesale price index. With the exception of a brief respite in 1997, in large part due to an increase in the consumption tax, inflation as measured by the GDP deflator has been consistently negative since 1994. The general decline in wholesale prices has been even larger and longer than that of the GDP deflator, although its sensitivity to commodity prices has made its decline less uniform. As Olivier Blanchard states, "The Phillips curve wisdom remains largely true in modern treatments of the determination of prices, wages, and output. . . As inflation is slowly decreasing today in Japan, this strongly suggests that output is below its natural level."9 The result is that real interest rates (bottom panel of figure 2) have remained relatively high for most of the period, despite nominal rates very close to zero.

At least since Irving Fisher, ${ }^{10}$ economists have viewed deflation as corrosive: it increases real debt burdens and inhibits purchases of durable goods. Nevertheless, some officials and observers have described the recent Japanese deflation as representing positive structural change, at least in part because they see deregulation and technical progress as responsible for some of the price declines. Bank of Japan Governor Masaru Hayami has stated, "These price developments have obviously been influenced by both supply and demand elements. . . . On the supply side, a variety of elements are at work, e.g., technological innovation, increase in efficiency in the distribution system, and deregulation, all of which exert a downward pressure on prices." "Kazuo Ueda, a member of the Bank of Japan's board, cites an example: "Uniqlo, which sells in Japan casual clothes manufactured in China, is generating a $20 \%$ or more return on assets. But the deflationary effects of the activities of such companies

9. Blanchard (2000, p. 190).

10. Fisher (1933).

11. Hayami (2001). 
Figure 2. Inflation and Interest Rates, 1976-2001

\section{Inflation}

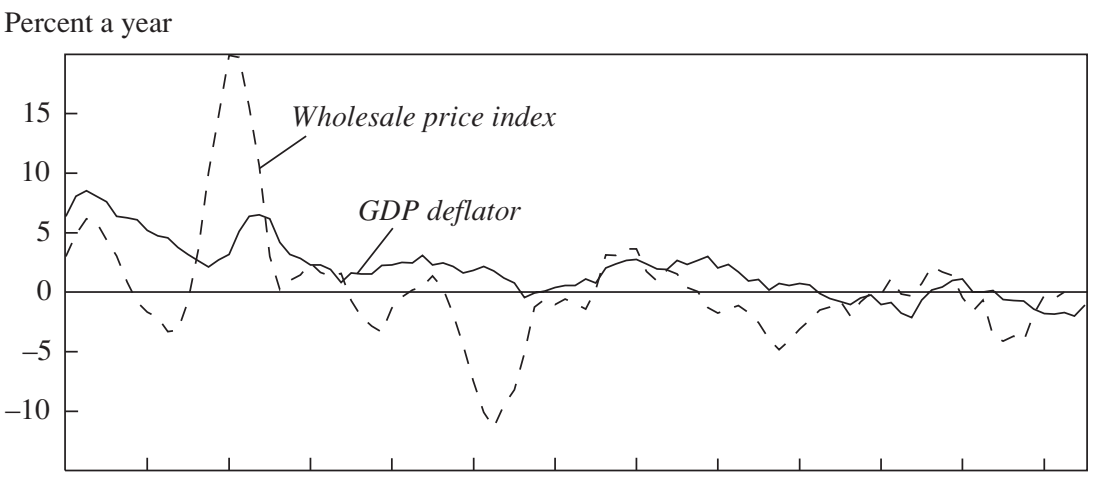

Three-month interest rate

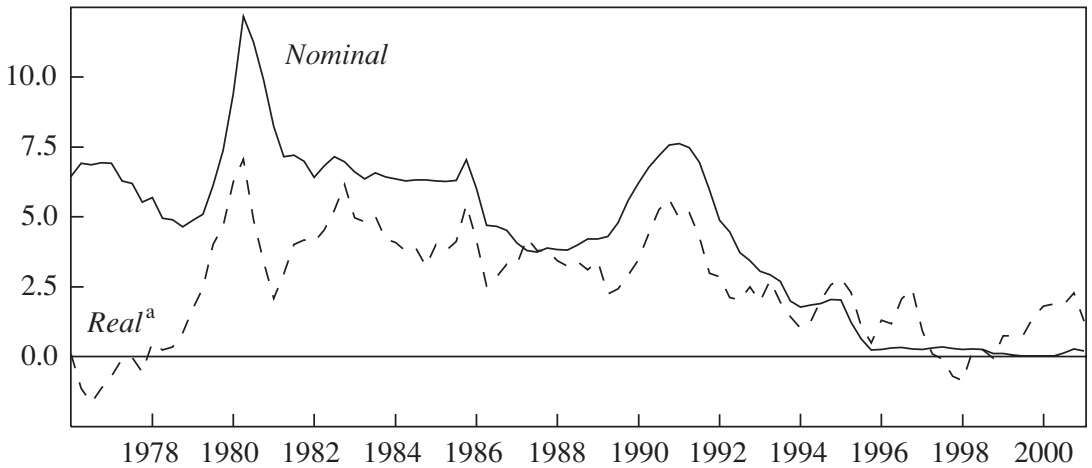

Sources: Economic and Social Research Institute, International Monetary Fund, and Board of Governors of the Federal Reserve System.

a. Rate on certificates of deposit minus the percentage change in the GDP deflator over the preceding four quarters.

are taking a huge toll on Japan's more traditional firms." ${ }^{2}$ In a recent Bank of Japan working paper, Hitoshi Mio uses a bivariate structural vector autoregression (VAR) model to argue that large aggregate supply shocks are part of the reason for "the combination of price stability and output stagnation during two recessions [in Japan] in the 1990s."13 An obvious implication of this point of view is that what appears to be a recession is

12. Kazuo Ueda, "Defeating Deflation: Carrot and Stick for Japan's Banks," Asian Wall Street Journal, February 16, 2001, p. 6.

13. Mio (2001, p. 26). 
at least partly a positive development, and therefore monetary policy should not respond to negative measured inflation as much as it would if the price declines were all "bad" (that is, demand- or monetary policyinduced deflation).

This view, of course, embodies a fundamental confusion between relative price shifts, which, when measured as part of the consumption basket, produce on net a one-time drop in the consumer price index (CPI), and declines in the overall price level. If a technological advance or increased globalization gives the consumer greater purchasing power for a particular set of desirable goods that have fallen relatively in price, overall spending will rise as more of those goods are consumed, and presumably the increased demand will put upward pressure on overall prices (including wages). It is worth pointing out that the relative prices of technology goods such as computers have declined even more in the United States in recent years than they have in Japan, as have prices of imported goods, yet the United States has not suffered from deflation. ${ }^{14}$

Further undercutting the "good deflation" view is the observation that the measured CPI is biased upward in Japan..$^{15}$ The bias is due not only to the index's fixed-weight construction, but also to its exclusion of most products undergoing rapid technological change (such as personal computers and mobile phones), which would require hedonic pricing adjustment, and to the omission from its surveys of discount stores such as Uniqlo. ${ }^{16}$ Therefore the sources of "good" deflation, if they exist, cannot be contributing significantly to the measured deflation seen in the CPI to date. The deflation (adjusted for the upward measurement bias) must be general. Effective August 2001, the Japanese government changed the benchmark year for the CPI from calendar 1995 to calendar 2000, in part to address these omissions of technology products and discount stores; Mikihiro Matsuoka estimates that this will lower measured CPI inflation by 0.3 percentage point at an annualized rate, ${ }^{17}$ and indeed, in the first monthly data release on the new basis, CPI inflation was 0.3 percentage point lower.

14. We are grateful to Takeo Hoshi and Richard Jerram for discussion of these points.

15. Shiratsuka (1999) estimates the overall bias in the CPI at about 0.9 percentage point a year.

16. John H. Makin, "Japan's Disastrous Keynesian Experiment," AEI Economic Outlook, December 1996, p. 3; Shiratsuka (1999).

17. Mikihiro Matsuoka, "Depth and Duration of Current Downturn," Deutsche Bank Group Global Markets Research: Japan, Tokyo, May 17, 2001. 
Despite the prima facie case for a demand shortfall (chronic deflation), not to mention the mainstream academic consensus, some observers have claimed that Japan's protracted slowdown represents a "structural slump"- - a recession created by the massive reallocation of resources from unproductive sectors to more advanced, competitive industries. ${ }^{18}$ The popular view that Japan's economic system is somehow unsuited to today's international competition, and that corporate Japan is unable to adapt to life at the technological frontier (especially when that frontier involves "creative" industries such as software and biotechnology) has contributed to this interpretation. ${ }^{19}$ If correct, this would imply that countercyclical macroeconomic policies are likely to be ineffective (and wasteful) at best, and to interfere with needed structural adjustment at worst. As noted by Posen and by Paul Krugman, ${ }^{20}$ this view echoes the "liquidationist" views of then-Treasury Secretary Andrew Mellon and others who opposed macroeconomic stimulus during the Hoover administration in the United States.

The debate over these competing perspectives should not be overdrawn, however. Fears that an undue or premature emphasis on structural reform would obstruct the use of demand management policy (and thereby risk a crisis) have led some to occasionally attack a straw man. Most liquidationists admit that demand shocks have played a major part in the Japanese recession, and that some output gap exists (even if they believe potential output has dropped significantly). But they put great weight on the political economy argument that demand stimulus is a narcotic that prevents structural reform from taking place. ${ }^{21}$ By the same token, most recessionists (or "Keynesians," as the Japanese press often calls them) acknowledge at a minimum a special role for the financial sector and the cleanup of

18. Among those sharing aspects of this view are Roubini (1996); Asher and Smithers (1998); Tadashi Nakamae, "Three Futures for Japan: Views from 2020," The Economist, March 21, 1998, p. 25; Katz (1998); Porter, Takeuchi, and Sakakibara (2000); and McKinsey Global Institute (2000).

19. See Posen (2001b) for a summary of discussion on this issue as well as evidence indicating that, on all measurable outputs, Japanese research and development and hightechnology corporations remain as productive now as in the 1980s or before.

20. Posen (1998); Krugman (2000).

21. See, for example, Richard Katz, "Japan's Economic Outlook: No Chance for 'Soft Landing," Oriental Economist, September 1998, pp. 1-3; Makin, "Japan's Disastrous Keynesian Experiment"; Katz and others (2000); and Masuda (2001). We return to this and other issues of political economy briefly in our concluding section. 
nonperforming loans. ${ }^{22}$ But not only do they deny a conflict between macroeconomic stimulus and structural reform, they indeed claim a complementarity. ${ }^{23}$ The labels themselves are not important.

What is important for macroeconomic policy to learn from the Japanese experience is whether the recession has exacerbated Japan's structural problems, or vice versa, and therefore whether macroeconomic (including banking sector) policy could have to some degree alleviated those problems. Few would deny that there is ample room for structural reform in Japan. ${ }^{24}$ Detailed assessments of the progress in recent years on regulatory and systemic economic reform come to very pessimistic conclusions. ${ }^{25}$ Japan remains aptly described as having a dual economy, with 10 to 15 percent of employment in highly competitive exportoriented sectors and the rest in varying degrees of protected backwardness, with some of the least competitive sectors being construction, retail trade, and finance, insurance, and real estate. ${ }^{26}$

Yet the ten-year slump in the Japanese economy has done little to reallocate resources away from the less efficient sectors. In fact, of the sectors depicted in figure 3, the only one to show a pronounced decline in employment is manufacturing, which, if efficiency were a criterion, should have been gaining employment relative to the other sectors (even if shedding employment overall). ${ }^{27}$ Over the past three years, the Economic Planning Agency's index of full-time employment has fallen 1.4 percent for

22. In a particularly sophisticated example of this approach, Kobayashi and Inaba (2001) apply the "disorganization" model of Blanchard and Kremer (1997) to Japan to show how forbearance from corporate debt restructuring can exacerbate a normal business cycle downturn when distrust of defaulting borrowers raises suspicions about the commitment to "relationship-specific" investments.

23. See, for example, Posen (1998, chapter 5) and Mikitani (2000).

24. The annual OECD Economic Survey: Japan for 1996-2000 provides a measured review of the various areas needing reform and the potential benefits.

25. See, for example, Carlile and Tilton (1998) and Lincoln (2001).

26. McKinsey Global Institute (2000) reviews in detail the sectoral differences within the Japanese economy. See also Katz (1998); Posen (2001b); Gillian Tett, "Out of the Ice Age," Financial Times, February 24, 2000, p. 20.

27. In the summer of 2001, Fujitsu, Hitachi Matsushita Electric, NEC, and Toshiba all announced layoffs, among the largest ever by Japanese firms (see Akiko Kashiwagi, "Fujitsu to Cut 16,400 Positions," Washington Post, August 21, 2001, p. E3; David Ibison and Alexandra Harney, "Japan Plans £10bn Aid Package for Unemployed," Financial Times, August 27, 2001, p. 1). Although of course these layoffs are in response to the worldwide slump in demand for information technology goods, it is noteworthy that worldcompetitive Japanese high-technology manufacturing firms are responding to changing 
Figure 3. Distribution of Employment, by Sector, 1980-2000

Percent of work force

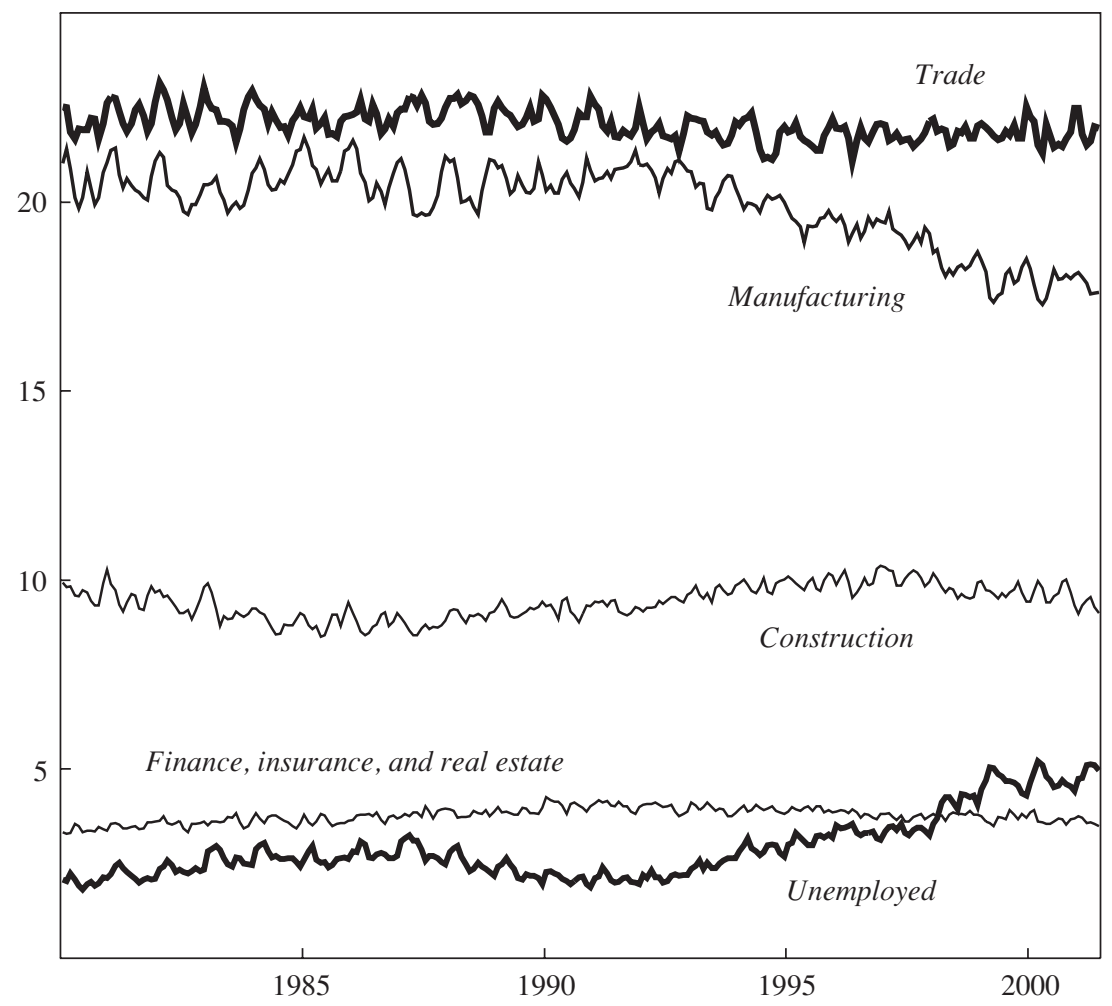

Source: Statistics Bureau and Statistics Center, Ministry of Public Management, Home Affairs, Posts and Telecommunications.

companies with thirty or more employees, but only 0.3 percent for companies with five or more employees. This suggests that the small-firmintensive retail, agriculture, and construction industries have retained labor while manufacturing industries, typified by larger firms, have shed labor. ${ }^{28}$ Yuji Genda and Marcus Rebick plot a Beveridge curve for Japan and observe, "Since 1994, vacancies have increased at the same time that unemployment has been increasing, suggesting that mismatch in the

market conditions by restructuring, whereas their counterparts in Japan's nontraded sectors have yet to restructure even after nearly a decade of declining or negative profits.

28. Mikihiro Matsuoka, "June Wages, Hours Worked," Deutsche Bank Group Global Markets Research: Japan, July 31, 2001. 
labour market is rising." ${ }^{29}$ (More recent data only extend the trend, particularly since the return to below-potential growth in the second half of 2000.) A structural slump that redistributed employment toward less efficient industries would be unworthy of the name, but such misallocation is only to be expected in a recession.

\section{Monetary Policy and Its Transmission}

The conjunction of two factors - the collapse of the Japanese banking system, and the binding zero bound on the Bank of Japan's instrument interest rate- has generated a rich discussion about the possibilities for expansionary monetary policy. ${ }^{30}$ All of these arguments have been framed in terms of abstract models, as is arguably appropriate for a situation that presents theoretical challenges. In practical policy terms, however, they all come down to the recommendation that the Bank of Japan do whatever is necessary to raise inflation, generate a depreciation of the yen, or at least create expectations of these developments. These prescriptions generally rely on a monetarist view of the world (in the sense of emphasizing quantities of monetary aggregates rather than interest rates), at least in the limit, and thus far have been based more on first principles than on actual experience. The goal in this section is to determine empirically the degree to which these "monetarist" channels have been operative.

A separate question is whether the Bank of Japan acted appropriately in light of the macroeconomic circumstances when conventional monetary policy measures would still have had an effect. That is a debate we do not intend to rekindle here. However, existing estimates of "Tayloresque" reaction functions for the Bank of Japan have all suggested that Japanese monetary policy was slow to respond to deflationary developments in the 1990s, and arguably displayed increased counterinflationary conservatism compared with earlier Bank of Japan behavior or the behavior of other major central banks. ${ }^{31}$ Such retrospective assessments, however, do not address whether

29. Genda and Rebick (2000, p. 98).

30. Examples include Bernanke (2000), Krugman (1998), McCallum (2000), Meltzer (1999), Posen (1998, chapter 5), Svensson (1999), and Taylor (2000), not to mention many nonacademic commentators.

31. See, for example, Bernanke and Gertler (2000), Kuttner and Posen (2000), and Jinushi, Kuroki, and Miyao (2000). 
Japanese monetary policy can affect nominal variables such as prices or exchange rates (or expectations thereof) in the current situation.

The monetary policy pursued in Japan in the 1990s and since has been conventional, in approach if not in goals, in the sense that it has relied almost exclusively on manipulation of the overnight nominal interest rate. Except for a hiatus in 1994, the Bank of Japan cut its target interest rate steadily but gradually from the onset of the recession in 1990 until it reached fractional levels in 1995. The central bank then shifted to what it called a zero interest rate policy in February 1999, with a reduction from 0.25 percent to 0.15 percent, followed by further reductions to rates as low as 0.02 percent. In April 1999 the bank made explicit the policy to keep interest rates at zero "until deflationary concerns are over." ${ }^{32}$ It subsequently reversed that policy in August 2000, increasing the rate once again to 0.25 percent, and reversed that reversal in March 2001. At that time the central bank announced a return to a zero interest rate, combined with a policy of "quantitative easing" intended to increase banking system reserves (which in fact rose from $¥ 4.2$ trillion in March to $¥ 8.4$ trillion in October) until the core CPI reaches zero or above.

The conduct of Japanese monetary policy throughout the 1990s therefore makes quantity effects difficult to discern, primarily because the sorts of overt, permanent changes in policy that have been advocated as remedies have not been present to any measurable degree. As monetary aggregates worldwide became less reliable indicators of inflation in the 1980s and 1990s, the emphasis in discussions of monetary policy justifiably shifted to inflation equations based on some form of the Phillips curve. Presumably with such an inflation process in mind, some have concluded that only a level of output greater than potential can raise prices. If true, this would create a serious catch-22 for Japan, where reflation is required to bring output back to potential. ${ }^{33}$ This dismisses by assumption the role that an increase in the quantity of money might play_although, as Ben Bernanke has emphasized, ${ }^{34}$ the monetization of real assets (or at least of assets that can be readily exchanged for real assets) must increase prices at some point; not to do so would violate the economy's resource constraint.

Although Bernanke's point is certainly correct in principle, our concern is of a more practical nature: whether money has retained an

32. Ueda (2000).

33. Lest one lose sight of the point: overcoming the zero bound on short-term interest rates is the goal; inflation is only a means to this end.

34. Bernanke (2000). 
exploitable link with prices in Japan, even absent an ambitious program of monetization. We address this question by reexamining some of the familiar relationships between money and prices, to see how those linkages have withstood the events of the 1990s. To gauge the likely impact of a permanent increase in money, therefore, it is first necessary to determine whether highly persistent increases have been observed in the past; in time-series argot, this is equivalent to determining whether the relevant series (money and prices) contain unit roots. Using this information, we can then determine the appropriate way to assess the long-run linkages between money and prices. The results turn out to be rather different for M2 and the monetary base.

\section{The Case of M2}

The first task is to determine the nature of changes in M2 and the degree to which permanent changes have been observed in the sample. To that end, table 1 displays standard augmented Dickey-Fuller tests for the null hypothesis of a unit root in the univariate representations of the variables in question. ${ }^{35}$ Regardless of whether the sample ends in 1989:4 or 2001:1, the test statistics are too small to reject the difference stationarity null hypothesis for the logarithm of M2. The logarithm of the price level also appears to be difference stationary regardless of whether the GDP deflator, the CPI, or the wholesale price index is used. These observations are more than mere econometric technicalities: they indicate that the sample does contain highly persistent changes in M2, allowing us to assess the long-run effects of such permanent changes. Similarly, because the price level is also integrated, something is affecting it in the long run; the question is whether that something is money.

The next step is to test for cointegration. These tests are based on the following equation:

$$
m_{t}=\theta_{0}+\theta_{y} y_{t}+\theta_{p} p_{t}+\theta_{r} r_{t}+v_{t},
$$

where $m, y, p$, and $r$ are, respectively, the logarithms of M2, real GDP, the GDP deflator, and the three-month nominal interest rate. If the variables are cointegrated, $v$ would be the error correction term, and the equation can

35. Four lagged differences are included to capture the serial correlation, and because a linear trend term is also included, the alternative hypothesis is that of stationarity around a deterministic trend. 
Table 1. Tests for Stationarity of Money and Price Series ${ }^{\mathrm{a}}$

\begin{tabular}{lcc}
\hline & \multicolumn{2}{c}{ Sample period } \\
\cline { 2 - 3 } Series & $1969-89$ & $1969-2001: 1$ \\
\hline M0 $^{\mathrm{b}}$ & -2.98 & $-3.65^{* *}$ \\
M1 & -2.67 & $-3.68^{* *}$ \\
M2 & -3.17 & -2.29 \\
GDP deflator & -1.10 & -2.11 \\
Consumer price index & -1.36 & -1.82 \\
Wholesale price index & -1.12 & -1.77 \\
\hline
\end{tabular}

Source: Authors' calculations.

a. Reports augmented Dickey-Fuller $t$ statistics calculated from regressions that include an intercept, a time trend, and four lagged differences. All variables are expressed as natural logarithms. The null hypothesis is that the series has a unit root. ** denotes rejection of the null hypothesis at the 5 percent significance level.

b. Data begin in 1970 .

be interpreted as a long-run money demand function. Four specifications are considered, differing in the restrictions imposed on the $\theta \mathrm{s}$. The first specification sets $\theta_{y}=\theta_{p}=1$ and $\theta_{r}=0$ (so that $-v$ is interpreted as the logarithm of "velocity"); the second sets $\theta_{y}=\theta_{p}$ (homogeneity of degree 1 with respect to nominal GDP) and $\theta_{r}=0$; the third sets the restriction that $\theta_{r}=0$; and the fourth is unrestricted.

Table 2 displays the estimated $\hat{\theta}$ s, along with Phillips-Ouliaris $\hat{Z}_{t}$ test statistics for the null hypothesis of no cointegration. The main result is

Table 2. Tests for Cointegration of Money, Output, Prices, and Interest Rates ${ }^{\mathrm{a}}$

\begin{tabular}{|c|c|c|c|c|}
\hline $\begin{array}{l}\text { Time period and } \\
\text { specification }\end{array}$ & $\hat{Z}_{t}^{\mathrm{b}}$ & $\hat{\theta}_{y}$ & $\hat{\theta}_{p}$ & $\hat{\theta}_{r}$ \\
\hline \multicolumn{5}{|l|}{$1969-89$} \\
\hline$\theta_{y}=\theta_{p}=1, \theta_{r}=0$ & -1.05 & 1.00 & 1.00 & \\
\hline$\theta_{y}=\theta_{p}, \theta_{r}=0$ & -2.08 & 1.23 & 1.23 & \\
\hline$\theta_{r}=0$ & $-4.74 * *$ & 1.87 & 0.74 & \\
\hline Unrestricted $^{c}$ & -2.64 & 1.90 & 0.66 & -0.0014 \\
\hline \multicolumn{5}{|l|}{ 1969-2001:1 } \\
\hline$\theta_{y}=\theta_{p}=1, \theta_{r}=0$ & -1.22 & 1.00 & 1.00 & \\
\hline$\theta_{y}=\theta_{p}, \theta_{r}=0$ & -1.81 & 1.28 & 1.28 & \\
\hline$\theta_{r}=0$ & -3.49 & 1.74 & 0.82 & \\
\hline Unrestricted $^{c}$ & -2.11 & 1.77 & 0.74 & -0.0008 \\
\hline \multicolumn{5}{|c|}{$\begin{array}{l}\text { Source: Authors' calculations. } \\
\text { a. Estimated from the following regression: }\end{array}$} \\
\hline \multicolumn{5}{|c|}{$m_{t}=\theta_{0}+\theta_{y} y_{t}+\theta_{p} p_{t}+\theta_{r} r_{t}+v_{t}$} \\
\hline \multicolumn{5}{|c|}{$\begin{array}{l}\text { where } m_{t} \text { is M2, } y_{t} \text { is GDP, } p_{t} \text { is the GDP deflator, } r_{t} \text { is the three-month interest rate, and } v_{t} \text { is the error term. All variables except } r_{t} \\
\text { are expressed as natural logarithms. } \\
\text { b. Phillips-Ouliaris test statistic. Computed from augmented Dickey-Fuller regressions with four lags on the residuals from } \\
\text { the regression above. ** denotes significance at the } 5 \text { percent level. } \\
\text { c. Data begin in } 1973 \text {. }\end{array}$} \\
\hline
\end{tabular}


that, for the sample ending in 1989:4, there is reasonably strong evidence for cointegration in the third specification, consistent with a role for M2 as a long-run anchor for prices. ${ }^{36}$ Long-run money demand is highly elastic with respect to real GDP $\left(\hat{\theta}_{y}=1.72\right)$, and nearly homogeneous of degree 1 with respect to the price level.

Extending the sample through 2001:1 weakens the evidence for cointegration. In the extended sample the Phillips-Ouliaris test statistic is not quite large enough in absolute value to reject the null of no cointegration at the 10 percent level. Failing to find cointegration does not, however, imply that M2 has no long-run impact on prices, only that there is no stable long-run relationship in levels. Figure 4 shows the actual path of M2, along with the path predicted by the cointegrating relationship estimated up through 1989:4. The figure shows that, since 1990, M2 has been lower than would have been predicted based on the pre-1990 relationship. In other words, the decline in M2 growth is somewhat larger than the deceleration in real GDP and prices would have warranted. This result is the opposite of what one would have expected in a liquidity trap, but consistent with a substitution of the public's assets out of banks' liabilities.

The impact of an expansion in M2 on prices is shown in the impulse response functions calculated from the error correction form of the model (left-hand panel of figure 5). ${ }^{37}$ Not surprisingly, increases in M2, which tend to persist, have similarly sustained effects on prices. Consequently, there is a sound empirical basis for believing that an increase in M2 would eventually lead to inflation in Japan, even controlling for the effect of money supply expansion on output (presumably through credit creation, which is currently impaired). The monetarist approach therefore suggests that, if M2 could be expanded, above-potential growth is not a precondition for increasing inflation.

\section{The Case of the Monetary Base}

Exploiting the link between M2 and prices may be difficult in practice, however, because the quantity of M2 is beyond the central bank's direct

36. Including the interest rate adds little and restricts the sample to a shorter time period, which makes it difficult to reject the null hypothesis of no cointegration in the fourth specification.

37. Very similar results are obtained from a VAR in levels that does not impose the constraint implied by cointegration. 
Figure 4. Actual and Predicted Paths of M2, 1969-2001

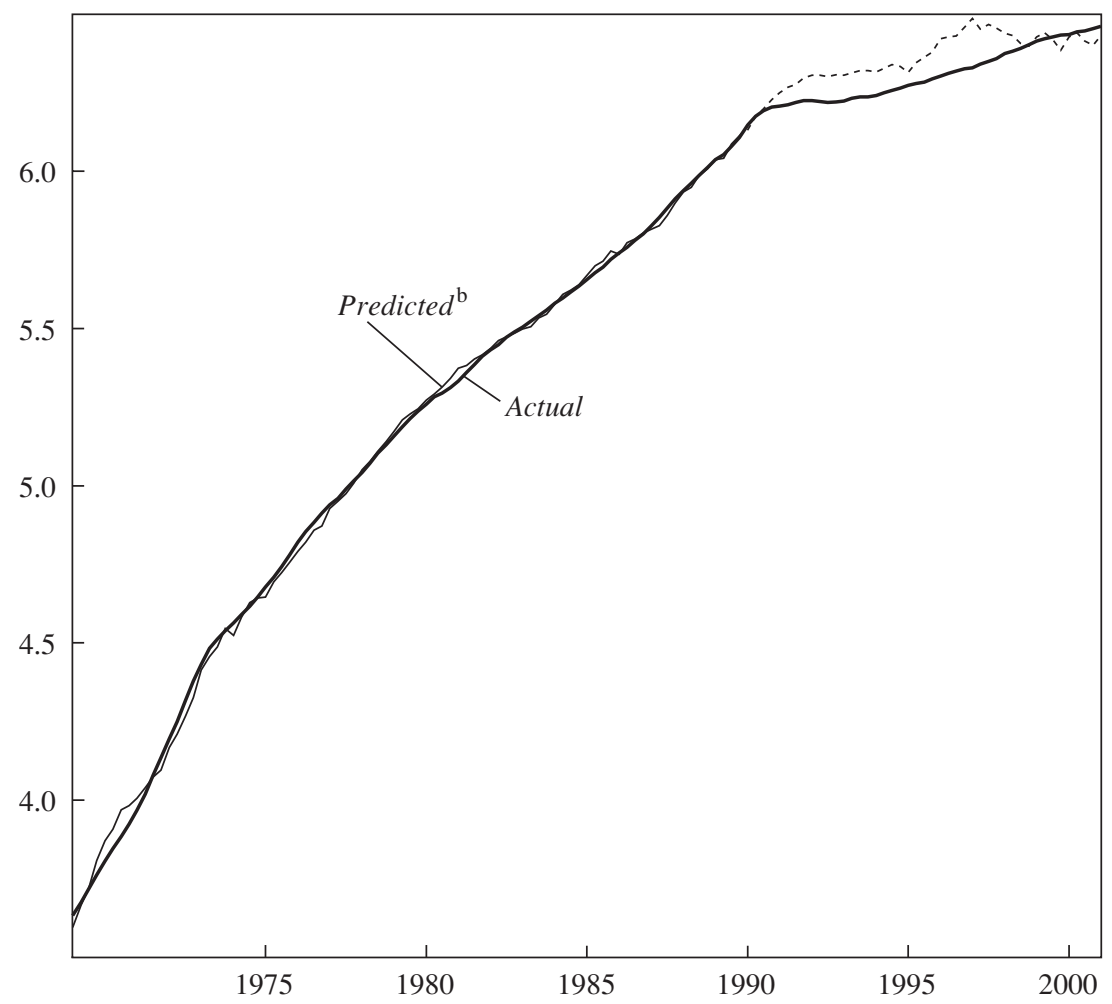

Source: Authors' calculations based on data from the Economic and Social Research Institute and the Board of Governors of the Federal Reserve System.

a. Expressed as logarithms. Dotted line indicates projections (1990:1-2001:1).

b. Estimated for 1961-89 using equation 1 under the restriction $\theta_{r}=0$.

control. And in fact, growth in base money (M0) has increasingly outstripped that of M2, as evidenced by the decline in the M2 multiplier (figure 6). Based on the Dickey-Fuller test statistics in table 1, the logarithm of the monetary base appears to be trend stationary, meaning that the sample contains no persistent deviations from a linear trend. ${ }^{38}$ In fact, the evidence for trend stationarity is even stronger for the full sample than it is for

38. This trend stationarity suggests that M2's nonstationarity emanates from persistent movements in the M2 multiplier rather than any permanent changes in the base. Whether this decline stems from an increase in the currency-to-deposits ratio or the reserve-todeposits ratio merits further investigation. Either way, a significant increase in the monetary base would be required to offset the impact of the multiplier's decline on M2. 
Figure 5. Impulse Response of Prices to Money Supply Shocks
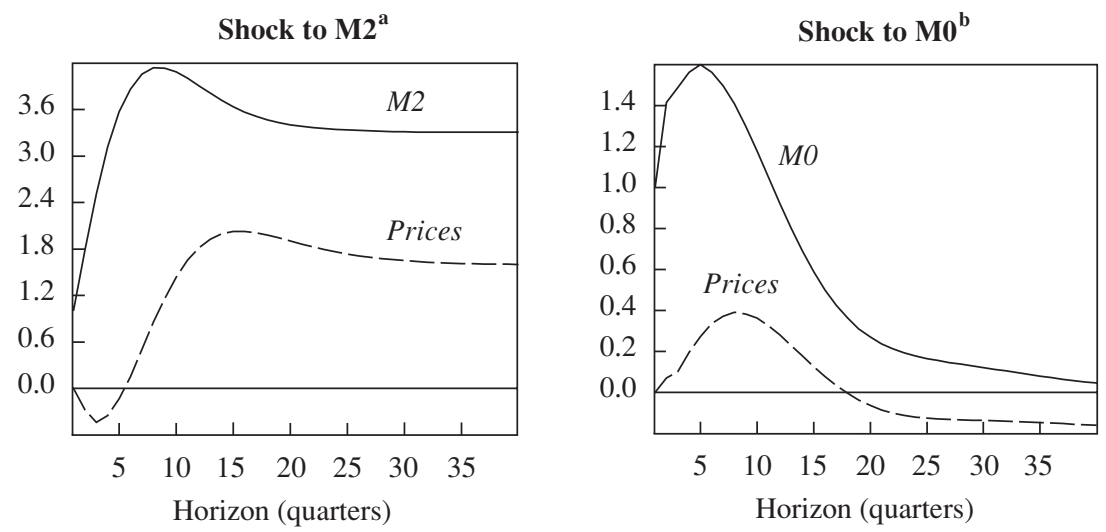

Source: Authors' calculations based on data from the Economic and Social Research Institute and the Board of Governors of the Federal Reserve System.

a. Responses are based on a three-variable vector error correction model that includes real GDP, the GDP deflator, and M2 (all expressed in logarithms), and an error correction term.

b. Responses are based on a three-variable VAR that includes real GDP growth, growth in the GDP deflator, the logarithm of M0, and a linear time trend.

the sample ending in 1989:4. In a statistical sense, therefore, a policy of permanently increasing base money has not yet been tried in Japan. This creates a practical econometric problem: assessing the impact of permanent fluctuations in the monetary base is difficult when no permanent changes have been observed. The best we can do is, first, to see whether the price level has at least kept up with the deterministic trend in the monetary base, and second, to assess the impact of transitory deviations from that trend.

To examine the response of prices to trend $\mathrm{M} 0$ growth, we regressed the logarithm of the price level on the monetary base and real GDP (that is, we used the inverted form of equation 1) through 1989:4 to forecast the price level through 2001:1. Since M0 and prices are not cointegrated, and since deflation has occurred despite robust M0 growth, it is no surprise that the equation wildly overpredicts the price level since 1990.

To assess the impact of transitory movements in the monetary base, we used a VAR model with the same other variables used with M2, but modified it to treat M0 as trend stationary and to leave out the error correction term. The right-hand panel of figure 5 depicts the responses of prices, and of the monetary base itself, to a 1 percent shock to the latter. Consistent with its trend-stationary characterization, the monetary shock's 
Figure 6. M2 Multiplier, 1970-2001

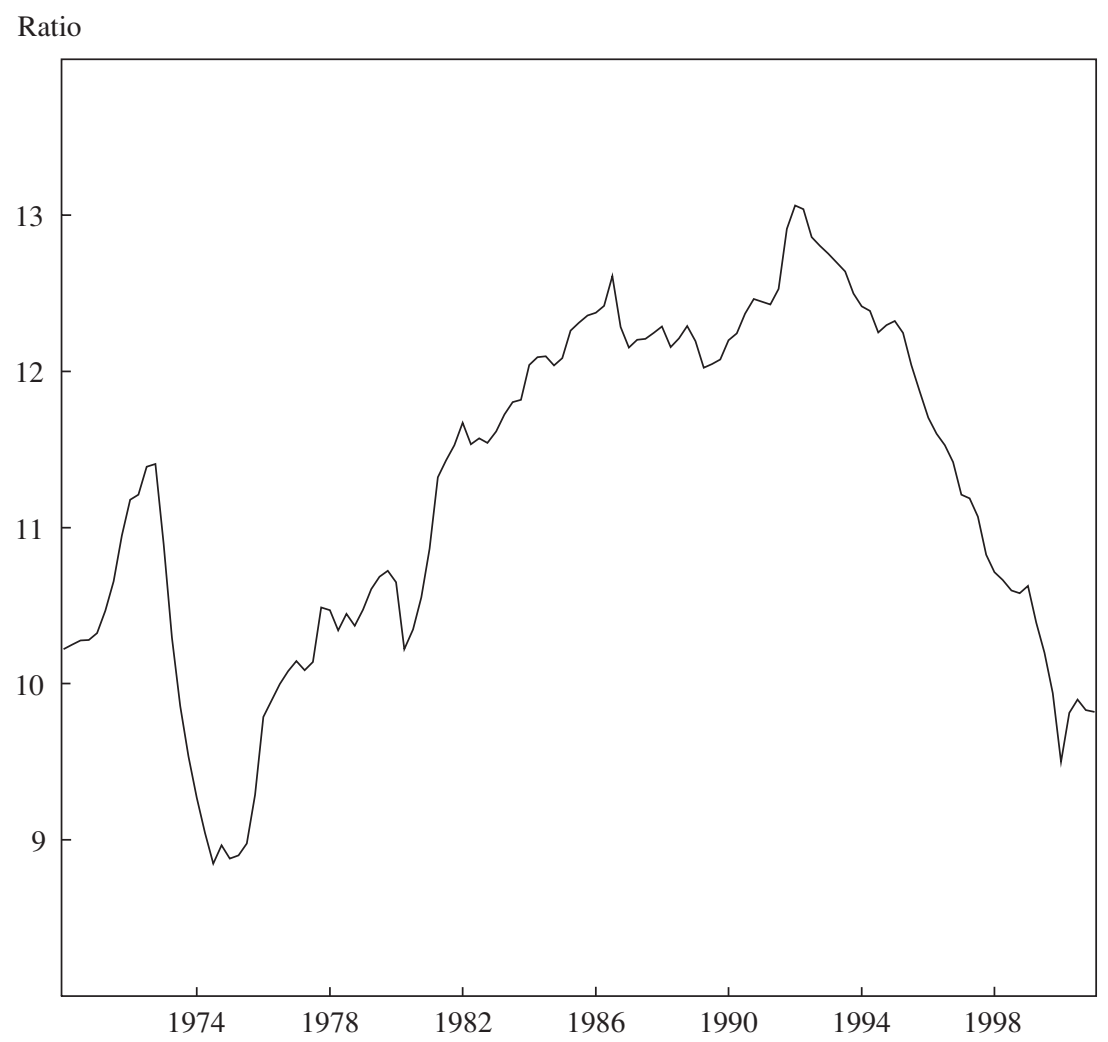

Source: Authors' calculations based on data from the Board of Governors of the Federal Reserve System.

impact on the base itself dies out over time. The shock initially increases prices, but the effect is reversed after a few quarters.

Even if we believed that a channel from high-powered money to other nominal variables in the economy still operated in Japan, we should not be surprised to find that short-lived fluctuations in M0 have only a minimal effect. In addition, given the weak link between M0 and M2 (and thus between M0 and prices), an increase in high-powered money will have only a limited effect if banks are unable or unwilling to lend the additional reserves. This reminds us that, even leaving aside any credit channel effects, a properly functioning banking system remains a key link in the transmission of monetary policy, as pointed out by Milton Friedman and 
Anna Schwartz nearly forty years ago. ${ }^{39}$ Yet even if broad money creation through the banking system is the primary and (usually) most reliable means of transmitting monetary policy, it is not the only channel.

\section{Monetary Policy and the Exchange Rate}

Another means by which a central bank could plausibly influence the rate of inflation is through altering the value of the domestic currency in the foreign exchange market. Leaving aside questions about the broader policy implications of a yen depreciation, if expansionary monetary policy were able to bring about a weaker yen, that would presumably have beneficial (that is, upward) effects on inflation expectations. A number of economists have advocated such a policy. ${ }^{40}$ The conventional channel through which monetary policy is transmitted to the exchange rate is through interest rates. Research has indeed established a link from interest rates to exchange rates ${ }^{41}$ albeit one whose dynamics are inconsistent with the pure uncovered interest rate parity condition. To a country facing a zero constraint on nominal short-term interest rates, however, this is of little comfort.

In theory, monetary policy could affect the exchange rate through other, non-interest rate mechanisms. One of these is through prices: if an increase in money is expected to lead to a rise in prices, then, so long as some form of purchasing power parity holds, the currency will eventually depreciate. (If price adjustment is sluggish, this will be associated with a real depreciation at first.) This mechanism is at the core of standard monetary models of the exchange rate. ${ }^{42}$ The problem is that evidence for cointegration between the monetary base and the nominal exchange rate in Japan is weak, and in any case, whether this channel is operative depends heavily on the viability of the money-prices connection, considered above.

A second possible channel is through the portfolio balance effect, whereby an increase in the volume of yen-denominated assets relative to assets denominated in other currencies leads to a depreciation of the yen. Unlike the uncovered interest parity condition, which assumes perfect substitutability between assets denominated in different currencies, portfolio

39. Friedman and Schwartz (1963). It also echoes the views of the Chicago oral tradition, as recounted by Tavlas (1998).

40. These include Blanchard (2000) and McCallum (2000).

41. See, for example, Eichenbaum and Evans (1995).

42. See, for example, Frankel (1984); Bosworth (1993). 
balance models assume that these assets are in fact imperfect substitutes in investors' portfolios. Despite the inherent plausibility of this assumption, however, empirical evidence for the portfolio balance effect is scarce; Jeffrey Frankel, for example, using the relative stocks of total assets, found that the coefficients on asset supplies were typically insignificant or had the "wrong" sign..$^{43}$

Regardless of which of these two channels is operative, the relevant question for monetary policy is whether increases in the monetary base can bring about a depreciation-and the extent to which this effect holds absent changes in interest rates. In light of the empirical failures of the more structured monetary, portfolio balance, and uncovered interest parity models, we use an unstructured VAR approach to assess this question. Our three-variable model includes the first differences of the relative log of real GDP (the logarithm of real Japanese GDP minus the logarithm of real U.S. GDP), the relative log of the monetary base (similarly calculated), and the yen-dollar exchange rate (defined so that an increase denotes a depreciation of the yen). We also estimate a four-variable version that includes the relative levels of three-month Japanese and U.S. interest rates.

In the three-variable model, shocks to the relative monetary base do result in a depreciation of the yen relative to the dollar, as shown in the top panel of figure 7 . This effect is also present in the four-variable model (middle panel). In fact, even with the relative monetary base ordered after the interest rate differential (meaning that it follows the interest rate differential in the causal chain), expansionary shocks to the base lead to a depreciation, as do negative shocks to the Japan-U.S. interest rate differential. The large estimated impact of monetary base shocks in the fourvariable model, however, is not necessarily supportive of the quantitative portfolio balance channel or of the monetary channel; since the expansionary base shocks also depress the interest rate differential, their effects could be transmitted through the interest rate.

To investigate this possibility, we recomputed the impulse response functions for the four-variable VAR with the base-to-interest-rate channel shut down (that is, with the interest rate differential "exogenized"). The estimated response in this case, shown in the bottom panel of figure 7, is

43. Frankel (1984). Dominguez and Frankel (1993) present some evidence more supportive of a short-run portfolio balance effect, in the context of foreign exchange intervention. 
Figure 7. Impulse Response of Yen-Dollar Exchange Rate to a One Percent Increase in Base Money ${ }^{\mathrm{a}}$

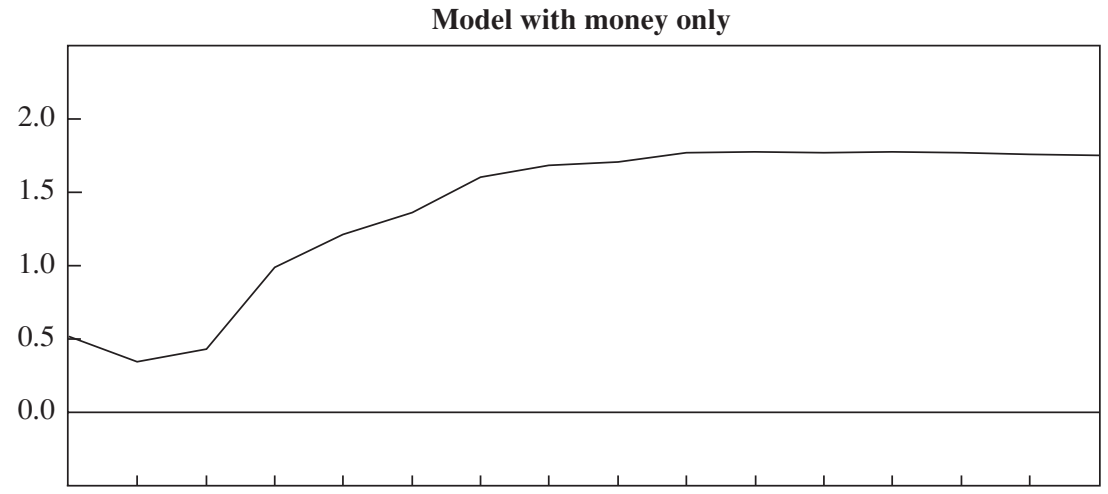

Model with money and interest rate

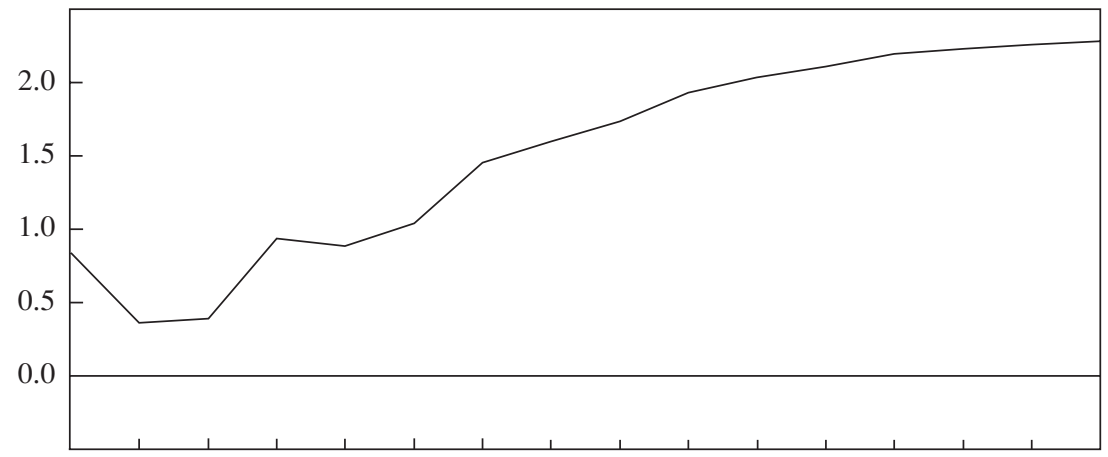

Model with exogenous interest rate

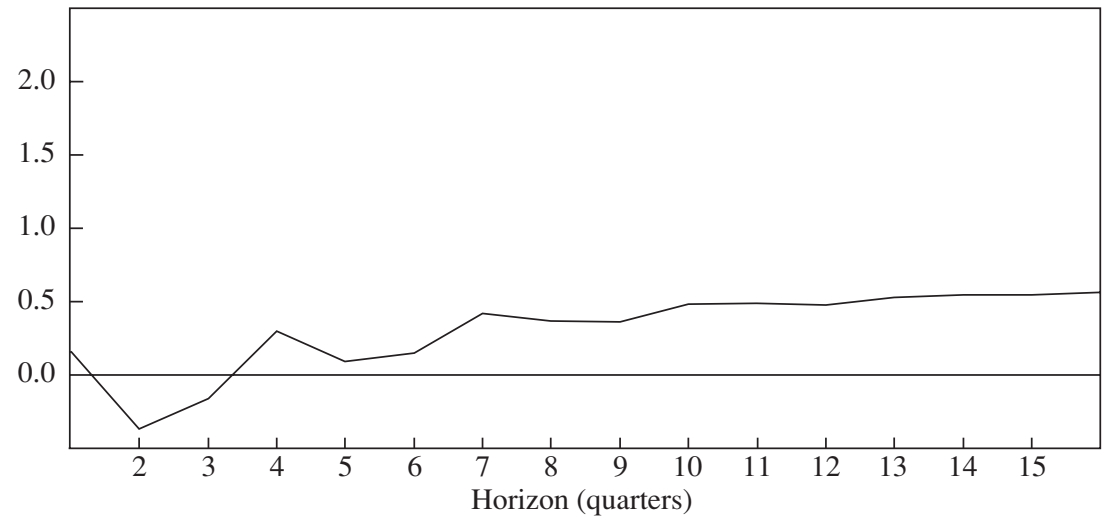

Source: Authors' calculations based on data from the Economic and Social Research Institute and the Board of Governors of the Federal Reserve System.

a. Parameters are estimated for 1976-2000 using quarterly data. Data for money base are average changes over the quarter. Data for the exchange rate are from the last month of the quarter. 
much smaller, indicating that changes in the monetary base affect the exchange rate largely through their effects on interest rates. These results are in line with existing empirical research on monetary and portfolio balance models of exchange rates and not unique to Japan. Nonetheless, the results are not encouraging if the goal is to affect the exchange rate by expanding the monetary base, at least using the sorts of "temporary" expansions observed in the sample to date. It must be noted that, as in the case of the link between money and prices, experience within the sample would be a poor guide to the likely impact of a more fundamental shift in monetary policy.

\section{Monetary Policy Announcement Effects}

With the efficacy of changes in high-powered money in doubt, macroeconomists find themselves stuck in a monetarist quandary: at some point, increases in the money stock must translate into inflation, but there is no evidence that below that undefined point the transmission effect is extant. Under conditions of a liquidity trap, even more than under normal conditions ${ }^{44}$ it would appear that interest rates are what matter, not monetary aggregates. At issue is the matter of expectations. As Krugman and Bennett McCallum, ${ }^{45}$ among others, make clear, if the central bank made a credible commitment that inflation rates would remain higher in the future, today's liquidity trap would be escaped. Blanchard states it very plainly:

\footnotetext{
So suppose the central bank wants to decrease the 10 -year real rate by, say, 200 basis points. All that is needed is for it to convince markets that the price level 10 years from now will be higher by 20 percent. . . . Indeed, one can argue that monetary policy works mostly-entirely? - through its effects on expectations.... The only thing specific to Japan today is that the emphasis is not on changes in future expected nominal interest rates, but on the expected future price level. This is not an essential difference. ${ }^{46}$
}

In other words, as long as we can expect that someday there will be a functioning banking system to move credit conditions, or sufficient interest rate differentials with trading partners to move exchange rates, there can be inflation when that day comes. And logically, if a sufficiently large and lasting amount of inflation can be created at some date in the future, it

44. As in Friedman and Kuttner (1992).

45. Krugman (1998); McCallum (2000).

46. Blanchard (2000, pp. 191-92). 
should have some effect on wage- and price-setting behavior in the present.

The efficacy of such an announcement effect has not been definitively established empirically, however, especially in an environment in which the M0-M2 connection is frayed, and the zero bound on nominal interest rates constrains exchange rate movements. ${ }^{47}$ In the case of Japan, most of the discussion has centered around whether the announcement of an inflation target would be sufficient to raise inflationary expectations. The hope of many advocating this view is that, by combining such an announcement with sufficient quantitative easing, the Bank of Japan would move inflation expectations, even if the quantitative measures themselves did not directly cause changes in interest or exchange rates. Several others, including members of the Bank of Japan's board and senior staff, have dismissed the idea that announcement effects could have an influence when the economy is in such straits. For example, Governor Hayami has stated, "The currently prevailing argument for inflation targeting includes dissipating the current excessive deflationary expectations of the public by raising their inflationary expectations. Can we really raise inflationary expectations just by announcing an inflation target?"48 If people's expectations are for the most part adaptive, and inflation consequently is largely the result of demand-pull, the announcement effects will be nil. ${ }^{49}$ (Another option is to run up sufficient government debt that inflationary expectations are piqued through that channel, but as that is a matter for fiscal policy, under the control of another agency, we consider that possibility in the next section.)

In a handful of cases elsewhere in the world, central banks have used announced targets in conjunction with policy actions to prevent or reverse deflation: Canada adopted an inflation target in 1992, Switzerland relied

47. Policy announcements have been shown to affect overnight interest rates through the "open mouth effect" discussed in Guthrie and Wright (2000), Woodford (2000), and Demiralp and Jordá (forthcoming). But in the contexts of those discussions, it is clear that open market operations remain a viable option for the central bank to enforce the announcement effect even in the short term.

48. Hayami (1999). See also Okina (1999a and 1999b), Yamaguchi (1999), and Shirakawa (forthcoming).

49. In recent years a surprisingly large number of observers of Japan who oppose more active monetary policy have taken this view. This is ironic because usually claims for the neutrality of monetary policy depend on arguments about forward-looking behavior. Of course, a similar irony applies in the other direction, with advocates of monetary expansion for the sake of stabilization relying on shifts in forward-looking expectations. 
on an existing monetary growth target when faced with deflation in 1982, and Sweden on a price-level target in the $1930 \mathrm{~s} .{ }^{50}$ The relevance to Japan of Canada and Switzerland could be questioned, as both countries (or at least Canada) had room to move interest rates, and there was some evidence of the ability of monetary expansion to move exchange rates and credit conditions. Sweden's pursuit of a price-level target during the Great Depression, however, holds out the hopeful precedent that a sufficiently strongly believed commitment to reflation could have an effect on current deflation.

Unfortunately, the experience of Japan thus far offers no clear evidence on the efficacy of announcements committing the central bank to higher future inflation. Only two recent announcements of significant changes in the monetary regime or in policy goals might have had a major impact on expected inflation or future nominal interest rates, and both of these would have contributed to expectations of tighter policy in the future. Although some market participants certainly do scrutinize every statement of every central banker for signs of changing intentions, ${ }^{51}$ at issue is the effect of major announcements intended to serve as commitment mechanisms and to move expectations among the public more broadly, independent of policy instruments.

The first announcement with the potential to durably move inflation expectations was the Diet's passage, on June 11, 1997, of the new Bank of Japan Law granting the central bank both goal and instrument independence. ${ }^{52}$ In keeping with the literature on central bank independence, this would be expected to reduce or remove the "inflation bias" of discretionary monetary policy, ${ }^{53}$ and long-term inflation expectations should

50. See Posen (1999), Svensson (1999), and Cargill, Hutchison, and Ito (2000, chapter 5) for such invocations in reference to Japan. The Swedish case is discussed in detail in Berg and Jonung (1998); Bernanke and others (1999, chapters 3 and 5) discuss the similarities of the Canadian and Swiss examples.

51. Cukierman and Meltzer (1986) and the literature that followed, on distinguishing "wet" from "dry" central bankers, give some theoretical foundation for doing so.

52. Debelle and Fischer (1994) define the distinction between independence to set the goal of policy and independence to pursue a given goal with instruments of the central bank's choosing. Cargill, Hutchison, and Ito (2000) provide the definitive treatment of the event in question.

53. See Rogoff (1985), Alesina and Summers (1993), and Cukierman (1992). This effect should not be overstated, however. The Bank of Japan had always been considered an outlier in studies of central bank independence because it scored low on the usual measures of legal independence (being under the control of the Ministry of Finance) yet delivered 
have dropped. What is unclear is whether the announcement effect took hold at the time of the law's passage or of its implementation (April 1, 1998). In our assessment we consider both dates as candidates for announcement effects. ${ }^{54}$

The second candidate for an observable announcement effect is a speech by Governor Hayami on March 21, 2000, to the Research Institute of Japan, titled "Price Stability and Monetary Policy." ${ }^{55}$ We identified this speech after going through all of Hayami's speeches listed on the Bank of Japan's World Wide Web site (in official English translations) as well as all official policy statements by its board, from the time of independence onward, looking for major shifts in reference to the institution's goals. ${ }^{56}$ The speech addresses a number of points regarding the goals of monetary policy and long-term inflation, in the form of explaining the central bank's opposition to inflation targeting proposals. These talking points then became standard language and content in officials' public statements and remain so today. ${ }^{57}$ In his opening, Governor Hayami notes, "Voices calling for additional measures on the monetary policy front have tended to become louder. And some have begun to argue for tolerating a little bit of inflation. In fact, we have been receiving an increasing number of questions asking our views on 'inflation policy' and inflation targeting." He then proceeds to give the central bank's views.

consistently low inflation; see Cargill (1993), Walsh (1997), and Cargill, Hutchison, and Ito (1997).

54. An interesting pair of questions for further research using the example of the Bank of Japan's gain in independence are whether time is needed for a central bank to establish a counterinflationary reputation (as is often presumed about the European Central Bank), legal status notwithstanding, and whether the change in legal status added anything, since the opposition to inflation in Japanese society was already accurately reflected in Japanese monetary policy.

55. Hayami (2000).

56. If we take seriously the idea of central bank independence, announcements about long-term inflation made by the central bank before April 1, 1998, should have been at least partially discounted as less than fully credible commitments.

57. Deputy Governors Sakuya Fujiwara and Yukata Yamaguchi included some of these points rebutting inflation targeting proposals in speeches given in the fall of 1999 (December 7 and October 19, respectively). These could be seen as trial balloons by the two other insiders on the central bank's policy board, but we feel that inclusion of these points in the governor's remarks from March 2000 forward is what elevates them to a policy announcement. 
The new points made by Governor Hayami in this speech include

- The suggestion that at least part of the deflation seen in Japan is due to structural reform and technological progress, rather than to a deflationary spiral: "Such phenomena cannot necessarily be regarded as pernicious price declines" (p. 3); "We cannot rule out the possibility that the economy could recover while the inflation rate is negative in terms of the existing price indexes." (p. 7)

- The explicit denial that an inflation target above zero is or should be the policy goal: "such a proposal is tantamount to artificially creating inflation ... at any cost" (p. 4); "Japan has had an average inflation rate of only slightly over one percent for nearly twenty years. Thus, it would need a very good reason to accept an inflation rate of 2 to 3 percent." (p. 8)

- The assertion that any credible commitment to higher inflation, particularly through the purchase of government bonds, would be completely passed through to long-term interest rates, with harmful effects: "A well-developed financial market would immediately discount this announcement and long-term interest rates such as the yield on government bonds would rise even before we actually observed inflation ... leaving the real interest rate ... unchanged." (p. 4)

- The point that "inflation is most likely uncontrollable once triggered. ... Some argue that [the Bank of Japan] can raise the inflation rate to 2 or 3 percent and then contain it around that level.... However, if we tried to contain inflation after it had gained momentum, we would need very strong monetary tightening." (p. 5)

- The concern that increasing purchases of government bonds by the Bank of Japan to the scale necessary to effect inflation would be dangerous: "Adoption of such a drastic policy would run the high risk of eroding not only fiscal discipline and the smooth functioning of financial markets but also the credibility of Japan itself." (p. 5)

To reiterate, none of these elements-that measured deflation in part reflects positive supply shocks; that greater-than-zero inflation targets are suboptimal; that the Fisher effect is complete and immediate; that inflation is accelerating rather than inertial at low levels; and that increased purchases of Japanese government bonds represent a real risk to fiscal discipline-are present in Governor Hayami's seventeen prior statements and four prior speeches posted on the Bank of Japan website. They are, 
however, all the subject of working papers and have been repeatedly invoked in speeches and statements by the governor, the two deputy governors, and senior staff, since that March 2000 speech. We therefore identify this as the date of another policy announcement in the direction of greater commitment to zero (or lower) measured inflation, and diminishing expectations of any more-aggressive expansionary measures.

If these two events produced announcement effects, the clearest place to see them would be in those forward-looking asset markets most sensitive to nominal interest rates and inflation-in particular, the market for Japanese government bonds. As figure 8 shows, however, neither announcement seems to have had much of an impact on long-term rates. ${ }^{58}$ This could be either because their effects on inflation expectations and expected future real interest rates were offsetting, or because the announcements themselves were not recognized as changing the commitments to the future course of policy. (By contrast, the 12.5-basis-point rate reduction in September 1998 and the discontinuation of the so-called zero interest rate policy in 2000 were associated with a decline and a subsequent increase in long-term rates.) Even if the governor's change of argument about inflation targets in his March 2000 speech was too obscure for the bond market to grasp, the fact that neither the passage nor the implementation of the new Bank of Japan Law had an effect on bond prices is somewhat surprising.

It is possible to interpret this as evidence that announcement effects are no more an effective channel of monetary transmission than the standard bank and portfolio channels, at least in the context of Japan's present situation. We consider this conclusion arguable, but likely premature. The majority of published works advocating inflation targeting in Japan suggest that the announcement of a positive target be accompanied by quantitative measures, and that both the announcement and the accompanying measures be ambitious..$^{59}$ The experience of the Bank of Japan since independence therefore does not cast much light on the efficacy of

58. Given the existence of only two announcement dates over a very short time span, and a relative lack of variation in policy instruments over the same period, "ocular econometrics" seems the most honest way to examine this question rather than adding these dates to a statistical test.

59. This characterization includes Bernanke (2000), Blanchard (2000), Cargill, Hutchison, and Ito (2000), Krugman (1998), Posen (1998), and Svensson (1999), although not all go as far as Krugman, who calls for responsible irresponsibility in the form of targeting 4 to 5 percent annual inflation for ten years. 
Figure 8. Response of Interest Rates to Announced Monetary Policy Changes, 1996-2001

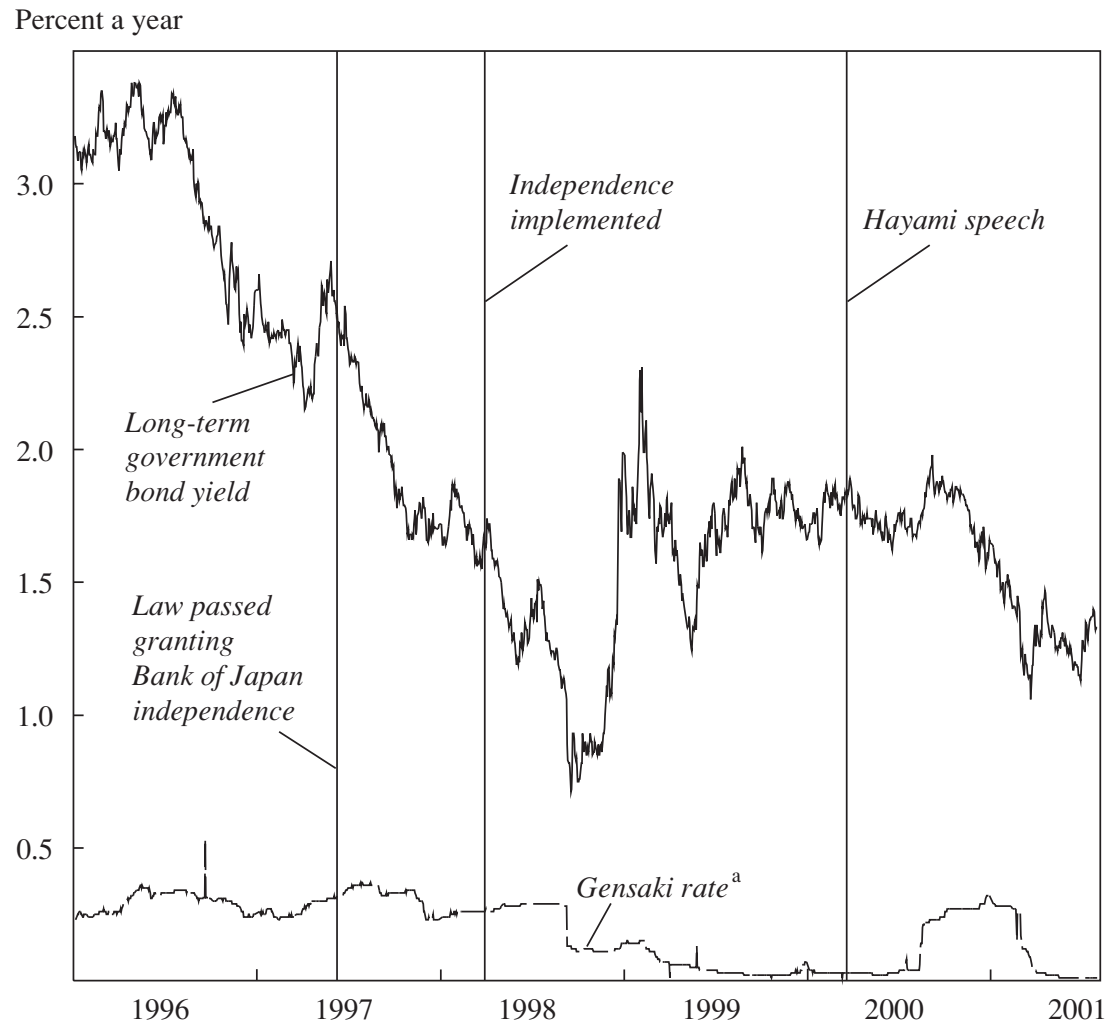

Source: Board of Governors of the Federal Reserve System. a. Repurchase agreement rate on government bonds.

policy announcements as yet. Thus an interesting test in this regard will be assessing the impact of its announcement, on August 14, 2001 (just before completion of the conference draft of this paper), that it would increase bank reserves and central bank purchases of Japanese government bonds. Although many market observers characterized that announcement as revealing a caving to political pressure (and thus a mark of diminished independence), the data so far indicate little response of inflation expectations. ${ }^{60}$

60. See David Ibison, "Doubt over BoJ's Independence," Financial Times, August 15, 2001, p. 8; Clay Chandler and Akiko Kashiwagi, "Bank of Japan Pledges to Boost Credit 
To some degree, however, the monetary policy question is moot. If the Bank of Japan can print money without causing inflation over some large range of values, while the banking system is unwilling to lend, it can monetize large quantities of government debt. ${ }^{61}$ If fiscal stimulus is effective, ultimately the role of monetary policy should be to accommodate expansionary fiscal policy. And if the monetization of government debt were to create inflation, it would solve the monetary problem as well. ${ }^{62}$ Even if one takes an alternative view on the manner in which the Great Depression ended, one that emphasizes monetary policy, ${ }^{63}$ one can still believe that fiscal accommodation is a way in which monetary policy can have a clear impact on both the real economy and inflation expectations. The question for fiscal policy, however, is whether it would itself be effective-a question to which we now turn.

\section{Fiscal Policy: Effective but Misunderstood}

As the previous section indicated, monetary policy's main role, especially in a liquidity trap, may ultimately be to accommodate fiscal policy. ${ }^{64}$ But the effectiveness of fiscal policy in Japan in the 1990s has been at least as controversial as the disputes over monetary policy. ${ }^{65}$ As with monetary policy, there has been open debate over the degree to which expansionary fiscal policy has even been tried, let alone whether it has been effective. To

Markets," Washington Post, August 15, 2001, p. E1; Miki Tanikawa, "Japan Tries to Grease Economy Again," New York Times, August 15, 2001, p. W1.

61. Krugman (1998) pointed this out forcefully in a reference to Romer (1993), as well as in Krugman (2000).

62. See Posen (1998, p. 62).

63. As in Bernanke (1995) and Eichengreen (1992).

64. Seidman (2001) reviews the arguments for why fiscal expansion is the recommended response to a liquidity trap. See also the discussion by the Brookings Panel of Krugman (1998) on this point.

65. Compare, for example, the speech by Summers (1998) advocating fiscal expansion with the following excerpt from a recent interview with the current under secretary of the Treasury for international affairs, John Taylor, who "said fiscal reforms that would rein in the public sector deficit should be seen as similar to those introduced by Mrs Thatcher in 1981, when spending was cut in the depths of a recession. He pointed out that in recent years repeated attempts at fiscal stimulus by Japan had been unsuccessful. 'In the last few years, an expansionary fiscal policy has been a mistake. To urge more on them now would also be a mistake." "Gerard Baker, "Interview: John Taylor-Japan 'A Drag on Recovery across Globe," Financial Times, July 25, 2001, p. 8. 
Figure 9. Government Revenue, Expenditure, and Budget Balance, 1970-2000

Trillions of yen

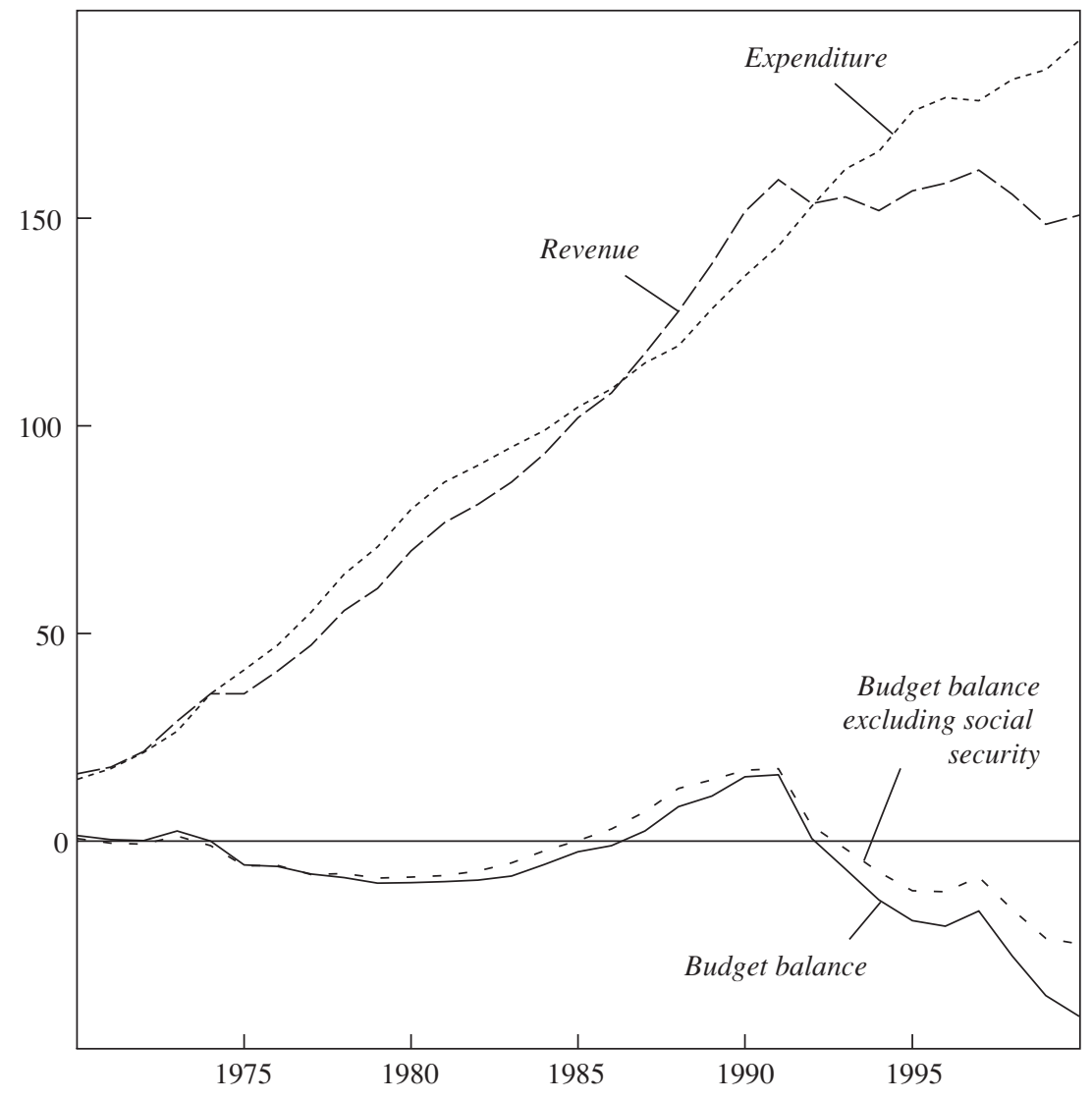

Source: Unpublished IMF data.

a surprising number of observers, the pattern depicted in figure 9 speaks for itself: the fiscal deficit has grown sharply, yet the economy has continued to stagnate. ${ }^{66}$ But as the figure shows, the bulk of the increase in

66. Milton Friedman recently wrote, "Does fiscal stimulus stimulate? Japan's experience in the '90s is dramatic evidence to the contrary. Japan resorted repeatedly to large doses of fiscal stimulus in the form of extra government spending. ... The result: stagnation at best, depression at worst, for most of the past decade." Friedman, "No More Economic Stimulus Needed," Wall Street Journal, October 10, 2001, p. A17. See also Ian Campbell, "Friedman Opposes Stimulus Package," UPI Newswire, October 9, 2001. 
the deficit is due to a plateau in tax revenue rather than to increased public expenditure or even discretionary tax cuts. This of course reflects the inverse cyclical relationship between output and tax revenue. If one applied a plausible tax elasticity of 1.25 to the output gap measures depicted in figure 1, the result would be a much-reduced estimate of the structural budget deficit; in fact, using the measure of potential based on a constant productivity trend growth rate of 2.5 percent a year all but eliminates the non-social security portion of the deficit. Moreover, as measured by the fiscal shocks derived from the structural VAR estimated below, fiscal policy has been generally contractionary since 1997.

In addition, the massive increase in Japanese government debt outstanding over the period has had little apparent effect to date on longterm interest rates: whether due to the passivity of Japanese savers, the sale of government bonds to quasi-governmental entities, or to (difficult to discern) accommodative monetary policy, there has been no sign of crowding out or of inflation fears. This fact has not gone unnoticed in the financial press. As early as February 1998, before three and a half more years of declining tax revenue and rising debt, The Economist observed, "[government bond yields] fell as the government pumped the economy with ... fiscal stimulus, as the yen plummeted by $40 \%$ from its high in the middle of 1995, and even as the government's debt climbed to 100\% of GDP. By late [1997] the Japanese government was able to borrow more cheaply than any other government in recorded history." ${ }^{67}$ As of July 2001, "In spite of the highest public debt to GDP ratio among the Group of Seven industrialised countries and the second worst sovereign credit rating, Japan has long enjoyed the lowest government bond yields. At 1.3 per cent, the yield on 10-year [government bonds] is significantly below the 5.5 per cent available on comparable US Treasuries." ${ }^{68}$ But with the exception of a brief panic-induced spike in rates in January 1999, more than half of which was reversed within two months, holders of Japanese government bonds have yet to take any significant capital losses.

Against these stable trends in revenue and long-term interest rates, the actual course of Japanese fiscal policy, both discretionary and passive, has been almost tumultuous, rather than one of unremitting spend-spend-

67. "That Sinking Feeling," The Economist, February 21, 1998, pp. 74-75.

68. John Thornhill, “Koizumi’s Bond Dilemma," Financial Times, July 30, 2001, p. 9. 
spend, as often assumed. Japan has a centralized, if arcane, fiscal system. ${ }^{69}$ The overall fiscal position of the Japanese government, whether on a yearly flow or on a balance sheet basis, is difficult to discern because of various institutional oddities and lack of transparency. In the fall of every year, after the main budget is passed in April, a separate "supplementary budget" is considered, which is the usual (but not the only) source of discretionary fiscal expansion. Public works projects are mostly required to have partial matching funding by local (prefectural, town, or city) governments, and there are massive reallocations of tax receipts back and forth between the central and lower governments. ${ }^{70}$ Meanwhile, an amount roughly equivalent to 40 percent of the entire budget is disbursed by the Fiscal Investment and Loan Program (FILP), which draws most of its funds from postal savings accounts and the government pension scheme and from other off-budget government agencies. ${ }^{71}$ The Ministry of Finance's Trust Fund Bureau coordinates FILP's investment plan with the budget process. Every year since 1994 has brought announcements of various tax reforms. ${ }^{72}$ Yet the Japanese tax base is extremely small, especially on the household side, where salaried urban workers pay a disproportionate share of the taxes, and small business owners and rural residents pay almost none. ${ }^{73}$

Leaving the relatively steady role of FILP aside and focusing on the sign and type (rather than size) of fiscal efforts, one can give a fair picture of Japanese fiscal policy since the bubble burst in $1990 .{ }^{74}$ As discussed elsewhere by Posen, ${ }^{75}$ given these institutional complications, estimating

69. See Ishi (2000) for a historical perspective; Balassa and Noland (1988), Bayoumi (1998), and OECD Economic Surveys: Japan, 1999, for institutional descriptions; and Schick (1996) for a comparison of U.S. and Japanese budget processes. Tax Bureau (2000) gives the official account of the tax system.

70. Another complication is that many local governments are today effectively bankrupt, indebted to local banks, and reluctant to undertake public works that have been commissioned. This in part explains why many government spending projects are never completed, even when the expenditure is listed in the budget. See Ishii and Wada (1998).

71. See Bayoumi (1998).

72. See Watanabe, Watanabe, and Watanabe (2001) and Tax Bureau (2000).

73. See Balassa and Noland (1988).

74. Posen (1998, chapter 2); OECD Economic Surveys: Japan, 2000; IMF (2000); and Bergsten, Ito, and Noland (2001) give more detailed accounts of the policies undertaken over this period. Asako, Ito, and Sakamoto (1991) provide an excellent account of "the rise and fall of [the] deficit in Japan, 1965-90."

75. Posen (1998, chapter 2). 
the mamizu ("true water") of any Japanese fiscal stimulus requires great care. The Japanese government introduced the first of a series of stimulus packages of public works in August 1992 and April 1993, but the net incremental expenditure was small: 2 percent of GDP in total, versus an announced combined size of 5 percent of GDP. The Diet passed a special income tax reduction in November 1994, to take effect in fiscal year 1995, amounting to 0.6 percent of GDP. ${ }^{76}$ The tax cut not only was stated to be temporary, to be reversed at the start of fiscal 1997, but was to be accompanied then by an increase in the national consumption tax (a value-added tax) from 3 percent to 5 percent. At the time, Prime Minister Tomiichi Murayama and senior budget officials cited concern about the looming demographic threat as the primary reason for the tax consolidation and the shift to indirect taxes. Some belief in the power of an expansionary consolidation, due to Japan's debt situation, was also invoked as a reason for the planned tax increase..$^{77}$ In June 1996 the Tax Commission (an advisory body to the prime minister) and then the Diet reaffirmed the plan. In April 1997 contribution rates to social security were increased along with the repeal of the temporary income tax cut and the implementation of the consumption tax increase. The tax burden rose by nearly 2 percent of GDP, more mamizu than any of the fiscal stimulus packages implemented up to that time.

A recession and a series of financial failures hit Japan later that year. (We defer to our analyses below the question of whether the 1997 tax rise caused a significant portion of the contraction.) In response to these events as well as to international pressures stemming from the Asian financial crisis and an electoral setback for the Liberal Democratic Party in July 1998, large stimulus packages were announced in both April and November. These included front-loaded public works to make up for the falloff in public spending in the second half of 1998 (and creating such a shortfall in the second half of 1999), as well as a combination of permanent income tax rate cuts, primarily for corporations and the top personal income tax bracket. According to the IMF, these initiatives contained 4 percent of

76. The Japanese government fiscal year runs from April 1 to March 31.

77. See David Holley, "Japan Approves a Tax Cut Plan; U.S. Lukewarm," Los Angeles Times, November 26, 1994, p. D1; "Editorial: Drastic Reforms Must Be Carried out," Daily Yomiuri, June 21, 1996, p. 13; William Dawkins, "Japan Confirms Sales Tax Increase," Financial Times, June 26, 1996, p. 6; and the account in Posen (1998, p. 50). 
GDP in "real water" measures. ${ }^{78}$ In November 1999 the government passed another large stimulus package, consisting mostly of promised public works spending amounting to 1.5 percent of GDP, but given the need for matching funds from local governments (the central government was to provide half the total), the full expenditure was not implemented. The initial fiscal 2000 budget set public works expenditure at the same level as in the fiscal 1999 initial budget, meaning that public works spending was set to decline by the amount added in the supplementary budget of November 1999. The October 2000 supplementary budget was smaller than in preceding years, even on an announcement basis. ${ }^{79}$

This ample variation in fiscal policy, moving from expansionary to contractionary and back to expansionary, on both the tax and the spending sides, with some tax measures temporary and others permanent, provides a rich basis for econometric investigation, in contrast to the almost unvarying monetary stance examined above. Our first consideration is simply whether the fiscal impulses had the expected sign, and what impact they had. As many observers have stressed, traditional public works in Japan more closely approximate the building of pyramids in hinterlands, famous to macroeconomics undergraduates, than do those in any other OECD country.$^{80}$ Some have indicated that they would expect the multiplier on such wasteful expenditures to be less than one.$^{81}$ Of course, Keynes maintained that even overtly wasteful public works projects were an effective source of fiscal expansion. Meanwhile, on the tax side, all tax cuts were

78. "The implementation of these packages was mostly felt in calendar 1999, however, due to the 3-6 month gestation period for public works projects, and owing to the fact that most of the tax measures were implemented through the FY1999 initial budget." IMF (2000, p. 29).

79. In fact, both the announced and the "real water" content of the October 2000 stimulus package were lower than in any since April 1995. See OECD Economic Surveys: Japan, 2000 , table 7.

80. Sixty percent of the Japanese coastline is today reportedly encased in concrete (Ian Buruma, "The Japanese Malaise," New York Review of Books, July 5, 2001, p. 39). Similar examples are easy to come by: see, for example, Martin Wolf, "Japan's Economic Black Holes," Financial Times, January 17, 2001, p. 21, and Bergsten, Ito, and Noland (2001, pp. 64-65).

81. In June 1998 the then-Vice Minister of Finance for International Affairs, Eisuke Sakakibara (1999, p. 45), expressed a contrary point of view: "Concerning the current fiscal package, I know that there have been various criticisms of it, but I think there is now a wider acceptance, even in the international community, of public works as a more effective means than tax cuts. In addition, under current circumstances, a strong multiplier effect can be expected...." 
preceded and accompanied by loud declarations by government officials that eventually taxes would have to go up. We directly examine the possibility of Ricardian equivalence below, but this fact also raises the possibility that even in the short term the multiplier might be very low.

\section{Taxes, Expenditure, and GDP}

To assess the impact of fiscal policy on the economy, we employ a structural three-variable VAR model adapted from the work of Blanchard and Roberto Perotti. ${ }^{82}$ Their approach is designed to identify the impact of fiscal policy while allowing for contemporaneous interdependence among output, taxes, and spending. The one-lag version of the BlanchardPerotti model can be expressed succinctly as

$$
\mathbf{A}_{0} \mathbf{Y}_{t}=\mathbf{A}_{1} \mathbf{Y}_{t-1}+\mathbf{B} \boldsymbol{\varepsilon}_{t},
$$

where $\mathbf{Y}_{t}=\left(T_{t}, E_{t}, X_{t}\right)^{\prime}$ is the vector of the logarithms of real tax revenue, real expenditure, and real GDP, and $\boldsymbol{\varepsilon}_{t}$ is interpreted as a vector of mutually orthogonal "shocks" to the three jointly endogenous variables.

Following Blanchard and Perotti, real GDP is allowed to have a contemporaneous effect on tax receipts, but not on expenditure. Taxes do not depend contemporaneously on expenditure, or vice versa, although tax "shocks" are allowed to affect spending within the year. This assumption conforms to the institutional setup for fiscal policy in Japan, where taxes are mostly collected from withholding and consumption, spending mostly is implemented with a lag, and both automatic stabilizers and the size of the public sector are limited. ${ }^{83}$ With these assumptions imposed, the model can be written as

$$
\begin{aligned}
& T_{t}=a_{0}^{13} X_{t}+a_{1}^{11} T_{t-1}+a_{1}^{12} E_{t-1}+a_{1}^{13} X_{t-1}+\varepsilon_{t}^{T} \\
& E_{t}=a_{1}^{21} T_{t-1}+a_{1}^{22} E_{t-1}+a_{1}^{23} X_{t-1}+b^{21} \varepsilon_{t}^{T}+\varepsilon_{t}^{E} \\
& X_{t}=a_{0}^{31} T_{t}+a_{0}^{32} E_{t}+a_{1}^{21} T_{t-1}+a_{1}^{22} E_{t-1}+a_{1}^{23} X_{t-1}+\varepsilon_{t}^{X},
\end{aligned}
$$

where $a_{1}^{i j}$ and $b^{i j}$ represent the $i$, jth elements of the $\mathbf{A}_{1}$ and $\mathbf{B}$ matrices. Thus $a_{0}^{13}$ captures the within-period elasticity of tax receipts with respect to

82. Blanchard and Perotti (1999).

83. It is also possible to identify the model under the assumption that spending shocks affect tax revenue contemporaneously. The results under this alternative assumption are virtually identical to those reported below. 
GDP, $b^{21}$ is the effect of tax shocks on expenditure, and $a_{0}^{31}$ and $a_{0}^{32}$ allow taxes and expenditure to affect real GDP contemporaneously.

The model in equation 3 is not identified, however, with seven parameters to estimate from the six unique elements of the covariance matrix of reduced-form VAR residuals. ${ }^{84}$ Our strategy, like that of Blanchard and Perotti, is to bring to bear independent information on the elasticity of tax revenue with respect to changes in real GDP, that is, the value of $a_{0}^{13}$. Specifically, we draw on the work of Claude Giorno and others and use a value of $a_{0}^{13}$ equal to $1.25 .{ }^{85}$ With that parameter fixed a priori, the model is exactly identified.

Comprehensive quarterly fiscal data for Japan are not readily available, unfortunately, and so we fit the model instead to annual consolidated central, state, and local fiscal data, compiled by the IMF, spanning fiscal years 1976 through 1999. The model also includes a linear trend and a trend interacted with a post-1990 dummy. ${ }^{86}$ Tax receipts are defined as direct and indirect tax revenue, excluding social security contributions. Expenditure corresponds to the sum of current and capital expenditure, less social security and interest payments.

Table 3 reports estimates of the model's parameters. The structural, contemporaneous coefficients on taxes and expenditure in the GDP equation confirm that, ceteris paribus, the within-year effect of both tax cuts and spending increases is indeed expansionary, although only the spending coefficient is statistically significant at the 5 percent level. Recognition of the endogeneity of tax revenue with respect to GDP is essential to this result; indeed, a naive ordinary least squares regression of GDP on taxes and expenditure, which fails to recognize this endogeneity, shows

84. For a complete discussion of the identification and estimation of structural VARs, see Hamilton (1994, chapter 11).

85. Giorno and others (1995a, 1995b). Similar results are obtained under a range of plausible alternative assumptions about the value of $a_{0}^{13}$. It would be possible to extend the work of Giorno and others to construct a time-varying elasticity that reflects the changing structure of the tax system, but because the results prove insensitive to the choice of $a_{0}^{13}$, this embellishment would be unlikely to alter the main conclusions.

86. The model makes no explicit distinction between temporary and permanent tax and expenditure changes, in part because the temporary tax changes enacted in Japan have been much smaller in magnitude than the permanent ones (see Watanabe, Watanabe, and Watanabe, 2001). Many of the supposedly permanent tax changes were offset by subsequent tax legislation, however, and this pattern should be picked up by the model's dynamics. 
Table 3. Estimating the Relationship among Tax, Spending, and Output with a Structural Vector Autoregression, 1976-99a

\begin{tabular}{lcccc}
\hline & & \multicolumn{3}{c}{ Equation } \\
\cline { 3 - 5 } Independent variable & Lag & Tax & Expenditure & GDP \\
\hline Tax receipts & 0 & & & -0.03 \\
Expenditure & 0 & & & $0.17^{* *}$ \\
Real GDP & 0 & $1.25^{\text {b }}$ & & $-0.25^{* *}$ \\
Tax receipts & 1 & $0.71^{* * *}$ & -0.12 & 0.02 \\
Expenditure & 1 & 0.04 & $0.78^{* * *}$ & $0.59^{* * *}$ \\
Real GDP & 1 & $-0.58^{*}$ & $0.66^{*}$ & $0.033^{* * *}$ \\
Tax shock & 0 & & -0.03 & $-0.038^{* * *}$ \\
Time trend & & -0.004 & -0.002 & \\
Time trend $\times$ post-1990 dummy & & -0.018 & -0.010 & 0.997 \\
Summary statistic & & & & 0.995 \\
Adjusted $R^{2}$ & & 0.996 & 0.85 \\
Durbin-Watson & & 1.66 & 2.30 & 1.85 \\
\hline
\end{tabular}

\footnotetext{
Source: Authors' calculations.

a. Estimated using a three-variable vector autoregression of real tax revenue, real government expenditure, and real GDP (see text for details). Data are annual and cover fiscal years 1976-99.* denotes significance at the 10 percent level, ** at the 5 percent level, and $* * *$ at the 1 percent level.

b. Imposed a priori as an identifying assumption.

c. From reduced-form VAR equations.
}

precisely the opposite result, with a coefficient of positive 0.16 on tax revenue. ${ }^{87}$

Table 4 reports the dynamic effects of tax and spending shocks. These multiyear effects are the relevant ones for policy analysis. Again, both tax cuts and expenditure increases have the expected expansionary effects, although there are some differences in the size of the effects stemming from the estimated dynamics of taxes and spending. Notwithstanding the characterization as permanent in intent of most Japanese tax law changes ${ }^{88}$ shocks to tax revenue tend to be relatively transitory, essentially disappearing after one year. ${ }^{89}$ Tax cuts are indeed expansionary: a 10 percent negative tax shock, which generates a cumulative 11.1 percent reduction in revenue over four years, leads to a 9.2 percent increase in GDP over the same period.

87. As noted by Blanchard and Perotti, estimating the third equation in the structural VAR is equivalent to using a measure of "cyclically adjusted" tax receipts (and a similarly adjusted measure of spending) as instruments for taxes and spending in a two-stage least squares regression.

88. As documented by Watanabe, Watanabe, and Watanabe (2001).

89. Because of the feedback between taxes and GDP, and the greater-than-unit elasticity of tax revenue with respect to GDP, the impact effect of a 10 percent tax shock on tax revenue is slightly less than 10 percent. 
Table 4. Dynamic Impact Response to Tax and Expenditure Shocks ${ }^{\mathrm{a}}$ Units as indicated

\begin{tabular}{|c|c|c|c|c|c|c|}
\hline \multirow[b]{2}{*}{ Years after shock } & \multicolumn{3}{|c|}{10 percent shock (percent) } & \multicolumn{3}{|c|}{$¥ 100$ shock (yen) } \\
\hline & $\operatorname{Tax}$ & Expenditure & $G D P$ & $\operatorname{Tax}$ & Expenditure & $G D P$ \\
\hline \multicolumn{7}{|l|}{ Negative tax shock } \\
\hline 0 & -9.6 & 0.3 & 0.3 & -96 & 3 & 16 \\
\hline 1 & -3.2 & 1.6 & 3.0 & -32 & 16 & 158 \\
\hline 2 & 0.0 & 3.6 & 3.2 & 0 & 36 & 168 \\
\hline 4 (cumulative) & -11.1 & 10.4 & 9.2 & -111 & 104 & 484 \\
\hline \multicolumn{7}{|c|}{ Positive expenditure shock } \\
\hline 0 & 2.0 & 10.0 & 1.6 & 20 & 100 & 84 \\
\hline 1 & 3.4 & 8.7 & 2.0 & 34 & 87 & 105 \\
\hline 2 & 3.7 & 7.7 & 1.7 & 37 & 77 & 89 \\
\hline 4 (cumulative) & 12.7 & 33.2 & 6.7 & 127 & 332 & 353 \\
\hline
\end{tabular}

The expansionary effect of tax cuts is easier to interpret (and more dramatic) when put in yen terms. To do so requires scaling up the response by the inverse of the share of taxes in GDP, which averaged 19 percent during the 1990s. Making this adjustment results in a cumulative $¥ 484$ increase in GDP in response to a $¥ 100$ tax cut. One explanation for the size of the response is that, over the sample period, tax cuts have tended to be associated with spending increases; in fact, the cumulative increase in spending is roughly equal to the fall in taxes..$^{90}$ Overall, GDP rises by more than twice the sum of the spending and tax effects.

Compared with tax changes, spending shocks in Japan have had smaller but more persistent effects, decaying only gradually over time: the cumulative effect over four years of a 10 percent spending shock is approximately 33 percent. The immediate impact of a 10 percent positive spending shock on GDP is 1.6 percent, which translates into $¥ 84$ for a $¥ 100$ spending increase, and the stimulus builds only slightly over time. One reason for the smaller estimated effect of spending than of tax shocks is that taxes tend to rise in response to positive spending shocks in this sample, partly offsetting the expansionary impact of the spending increase. This can be interpreted as evidence of the expensive maintenance of unproductive Japanese public works projects. Overall, the increase in GDP

90. Blanchard and Perotti (1999) found a qualitatively similar pattern in the U.S. data. 
is about 1.75 times the net effect of the spending minus the tax increasessmaller than the effect of tax shocks, but still a respectable multiplier.

These results show that, when it has been used, discretionary fiscal policy in Japan has in fact had the effects predicted in standard macroeconomic analyses. Both tax cuts and spending increases lead to higher real GDP, although the tendency for taxes and spending to move together has reduced the impact of spending increases. ${ }^{91}$ In that sense, the results corroborate the view that, because of institutional factors, one would expect tax cuts to be far more effective in today's Japan. ${ }^{92}$ The commonly held perception of fiscal policy's ineffectiveness in all likelihood stems from a failure to recognize the dependence of tax receipts with respect to GDP: as GDP falls, tax revenue shrinks, but to conclude from this that changes in the deficit have not affected growth would be incorrect.

\section{Taxes, Expenditure, and Saving}

The other salient issue for Japanese fiscal policy is the presence or absence of Ricardian effects. On many criteria - the connections of households across generations, the looming demographic burden, and the repeated public statements by officials and commentators about future budget difficulties, not to mention the obvious rapid rise in public debtit would appear that if forward-looking savers were to offset government debt anywhere, it would be in Japan in the 1990s. In the words of Allan Meltzer, "There is no way to finance these present and future [government] liabilities that will not involve higher future tax rates. The U.S. Treasury may not understand it, but the ordinary Japanese citizen has been told the truth about this problem for years. ${ }^{.93}$ David Asher and Robert Dugger warn "that Japan's 'financial Mount Fuji' is in serious danger of a major pyroclastic event with global fall-out." ${ }^{94}$ Peter Landers' 1998 article, "Japan:

91. Further work is needed to reconcile our results on the sizable effects of fiscal policy in Japan with the findings (using very different econometric approaches) of Bayoumi (2001) and Perri (1999) that fiscal policy had the expected sign but very small effects, and of Ramaswamy and Rendu (2000) that "public consumption had a dampening impact on activity in the 1990s." It is our initial evaluation that these other analyses did not take full account of the dynamic interactions among GDP, tax revenue, and expenditure in the way that we were able to, following Blanchard and Perotti.

92. This view is expressed in Posen (1998) and Bergsten, Ito, and Noland (2001).

93. Meltzer (1998, p. 1).

94. Asher and Dugger (2000, p. 1). 
Arthritic Nation," is a typical example of the extensive press coverage of the graying of Japan. ${ }^{95}$ In one of his last public speeches to the Diet, on March 8, 2001, then-Finance Minister Kiichi Miyazawa announced that Japan's finances were "very close to collapsing. We need fundamental fiscal restructuring aimed at rebuilding our finances in the 21 st century, looking 10, 20 years into the future." ${ }^{96}$ Asher asserts, "Overall, consumption in Japan is 'rationally suppressed' by structural factors outside of the range of monetary policy influence.... Moreover, with public anxiety over the ballooning government debt growing it seems that this is generating a fair degree of Ricardian 'precautionary saving.' "'97

Such fears would have a surface plausibility, given reasonable concern for oncoming demographic shifts as well as the apparent decline in the government's fiscal position. It is well documented that, on current trends, Japan faces a greater demographic challenge from its aging work force and increasing social security burden than any other developed economy. Andrew Smithers adds to the picture evidence of widespread weakness of local government balance sheets. ${ }^{98}$ Asher and Smithers point out that the government of Japan is potentially liable not only for local and central government debt, but also for the liabilities of the Trust Fund Bureau (to postal savings account holders) and of the state pension scheme. ${ }^{99}$ The OECD concludes that the rate of increase in Japanese government net debt (that is, debt outstanding after accounting for public assets and government holdings of its own bonds) "must soon be brought down for the dynamics of the debt not to become explosive, even if the pensions' problem is separately resolved." ${ }^{100}$ Simulations based on demographic projections by the IMF and by Hamid Faruqee and Martin Mühleisen yield daunting estimates of the policy changes and trade-offs that need to be addressed if Japan is to restore fiscal sustainability. ${ }^{101}$

The actual extent of the Ricardian offset to fiscal expansion, however, has not been assessed. We examine this question directly through an adaptation of the saving regressions used by Michael Hutchison. ${ }^{102}$ A key

95. Far Eastern Economic Review, July 16, 1998, pp. 10-13.

96. "Japanese Finance Minister Says Nation's Finances 'Near Collapse,'” Associated Press Newswires, March 8, 2001.

97. Asher (2000, p. 13).

98. Smithers (1999).

99. Asher and Smithers (1998).

100. OECD Economic Surveys: Japan, 1998, p. 85.

101. Faruqee and Mühleisen (2001).

102. Hutchison (1992). 
benefit of this approach is that it allows us to break out the differential effects on saving behavior of taxes, transfers, and public spending; these effects may indeed differ, especially in the Japanese context. The regression results are based on the equation

$$
S_{t}=\alpha+D_{t} \beta+\mathbf{x}_{t}^{\prime} \gamma+e_{t},
$$

where $S$ is saving measured as a percentage of GNP, net of taxes, plus social security payments; $D$ is a demographic variable (the old-age dependency ratio); and $\mathbf{x}$ is a vector of fiscal variables, each expressed as a percentage of GDP. ${ }^{103}$ Since $S$, as well as many of the regressors, appears to be difference stationary, this regression can be interpreted as a longrun cointegration relationship; as such, it abstracts from the dynamics of the relationships between fiscal policy and the rest of the economy, which are modeled more explicitly in the Blanchard-Perotti framework. ${ }^{104}$ Accordingly, Phillips-Ouliaris $\hat{Z}_{t}$ statistics are reported for the test of the null hypothesis that the residuals from the estimated regression are nonstationary (that is, that there is no cointegration). Following Hutchison, we start with the simplest measure of fiscal policy - the overall fiscal balance, or government net lending - and proceed from there to disaggregate that balance into its components. Table 5 shows the results.

The simplest regression, containing only the old-age dependency ratio and the fiscal balance, reported in column 5-1, displays a positive coefficient on the old-age dependency variable. This is inconsistent with the usual life-cycle interpretation, in which old people are dissavers, and suggests that this hypothesis does not adequately capture the behavior of Japanese elderly. ${ }^{105}$ The estimated coefficient on the balance is significant but quantitatively small: it implies that a 10 percent increase in the overall budget deficit is associated with a 1.2 percent fall in private saving. Adjust-

103. Following Hutchison (1992), we also tried including real GNP growth but found it to have no significant effect on saving. This is a logical result: because real GNP growth is stationary, it should have no long-run impact on saving.

104. As in the earlier analysis, the lack of comprehensive quarterly fiscal data forces us to use annual data, but since the relationship focuses exclusively on the long run, this is not a major handicap.

105. Using microlevel data, Horioka (1990, 1991, 1993, 1995, 1997), Horioka and Watanabe (1997), and Horioka and others (1996) come up with results more supportive of the life-cycle hypothesis, although the later studies give a more mixed picture than those at the start of the 1990s. This may indicate rising precautionary saving motives as the Great Recession dragged on and the prospect of unemployment or lost pensions rose. 
Table 5. Estimating the Long-Run Relationship between Saving and Fiscal Policy, 1976-99

\begin{tabular}{lccc}
\hline Independent variable & $5-1$ & $5-2$ & $5-3$ \\
\hline Constant & $30.62^{* * *}$ & $38.43^{* * *}$ & $37.90^{* * *}$ \\
Old-age dependency ratio & $0.11^{* * *}$ & $0.12^{* * *}$ & $0.17^{*}$ \\
Fiscal balance & $-0.12^{* *}$ & & \\
Tax revenue & & $-0.31^{* *}$ & $-0.32^{* *}$ \\
Government expenditure & & -0.10 & -0.09 \\
Social security balance & & & 0.30 \\
Net interest expenditure & & & 0.13 \\
Summary statistic & 0.432 & 0.514 & \\
Adjusted $R^{2}$ & 1.25 & 1.51 & 0.469 \\
Durbin-Watson & $-5.23^{* * *}$ & $-5.46^{* * *}$ & 1.48 \\
Phillips-Ouliaris & & & $-5.10^{* *}$ \\
\hline
\end{tabular}

Source: Authors' calculations.

a. The dependent variable is private saving as a share of GDP less taxes plus social security payments. Fiscal variables are expressed as a share of GDP. Data are annual and cover fiscal years 1976-99.* denotes significance at the 10 percent level, ** at the 5 percent level, and $* * *$ at the 1 percent level.

b. Revenue minus expenditure.

ing for the dependent variable's smaller denominator (income net of taxes plus social security payments is 79 percent of GDP over the 1990s), the yen-foryen effect is smaller still: only 0.9 percent of GDP for a 10 percent increase in the deficit. The $\hat{Z}_{t}$ statistic of -5.23 is sufficient to reject the null hypothesis of no cointegration among the three variables at the 1 percent level.

Column 5-2 replaces the overall fiscal balance with the two measures of spending and tax revenue used for the structural VAR above: expenditure net of interest and social security payments, and revenue excluding social security contributions. The coefficient of -0.31 on the tax revenue variable is significant and suggests a somewhat larger, but still modest, degree of saving offset. (The coefficient on expenditure has the "wrong" sign but is statistically insignificant.) Adjusting for the relative sizes of the variables’ denominators, the revenue coefficient implies a ¥24 increase in saving in response to a $¥ 100$ tax cut over the long run. (Given the de facto transitory nature of tax changes in Japan, some saving offset is to be expected, concerns about demographics and future obligations aside.) There is some apparent tension between this long-run response and the short-run multiplier on tax cuts estimated in the previous analysis, but this should not be overdrawn. In essence, the multiplier in table 4 is net of these offsetting saving effects to the degree they are incurred within the three-year horizon. 
The final specification, in column 5-3, adds to the previous specification the two remaining elements in the overall fiscal balance: the social security balance and net interest expenditure. Collectively, these four variables make up the overall fiscal balance (except for a very small "other revenue" category, which is omitted). Neither the social security balance nor net interest seems to bear a systematic relation to saving in Japan over the period: both are insignificant, and together they increase the adjusted $R^{2}$ only marginally.

One potential lacuna in this analysis is the failure to incorporate off-budget liabilities, such as pension shortfalls, debts of semipublic institutions, and likely insurance company failures. ${ }^{106}$ These are omitted not because they are unimportant, but because reliable time-series data are unavailable at this time; assembling these data and incorporating them into the analysis is a worthwhile direction for future research. Still, since these liabilities and their implications for future tax liabilities are even more opaque than on-budget taxes and expenditure, a large Ricardian offset from these sources seems unlikely, given that the more obvious factors had only a small impact on saving. Overall, our results provide little support for the Ricardian equivalence hypothesis under perhaps the most propitious conditions ever seen for it to hold: a rapid and large increase in public debt contemporaneous with a widely publicized projection of demographic dangers to social security benefits, in an economy already prone to high rates of saving.

The point is not that the sustainability of long-term debt is unimportant, and nothing in our results justifies such a dismissal. Instead, what is important for macroeconomic policy from these results is a reaffirmation of the ability to separate the long- and short-run fiscal policy issues, given the empirical evidence on saving behavior. Thus, whether or not an economy has a significant measure of public debt denominated in a foreign currency, held abroad, or borrowed at high interest rates-essentially whether or not it has domestically captive saving to draw upon-is the real question, because that is potentially the source of a binding fiscal constraint in the near term. Forward-looking behavior on the part of domestic savers regarding demographic or sustainability questions of debt ratios is not

106. See Asher and Smithers (1998) and Asher and Dugger (2000) for lengthy descriptions of these mounting contingent claims on the Japanese government, as well as Kotlikoff and Leibfritz (1998) for a generational accounting assessment of Japan's demographic imbalances. 
immediately relevant. This is why the idea of Francesco Giavazzi and Marco Pagano of "expansionary fiscal contractions" never made much sense for Japan-the high interest rates and foreign-denominated and foreign-held debt that characterized the success stories of Denmark and Ireland, and the somewhat lesser success of Italy, were not present. ${ }^{107}$ Otherwise, one is left solely with confidence-building effects to generate this kind of response to a fiscal contraction, and these do not seem to carry the day. As Stanley Fischer notes:

The mechanism was that the removal of the fear of unstable debt dynamics led to both lower interest rates and more consumption-in other words, to the view that fiscal contraction would generate a confidence effect. ... By putting the confidence effect center stage, they may have led to too much emphasis on the confidence-raising effects of fiscal contractions. That emphasis began to change, at least in the IMF, as a result of Japan's experience in mid-1997. ${ }^{108}$

In fact, for large, relatively closed economies like Japan or the United States, one can join Laurence Ball and Gregory Mankiw, and Willem Buiter and Kenneth Kletzer, in asking, "Who's afraid of the public debt?" 109 So long as financial crowding out, excessive monetization and inflation, and bankruptcy of the treasury are not current threats, the short term can be separated from the long term: responsible stabilization policy today to maximize growth today is not harmful and indeed is perhaps the optimal response to long-run sustainability issues. ${ }^{10}$

Clearly, our results leave an important fiscal policy issue unaddressed, namely, the relative effects of temporary versus permanent fiscal policy measures. The ostensibly temporary consumption tax reduction before April 1997, and the explicitly finite new condo construction tax credit of early 1999, were widely viewed as having large intertemporal substitu-

107. Giavazzi and Pagano (1990). Bergman and Hutchison (1999) make a provocative, and to us largely persuasive, case that even in the Danish 1982 fiscal reform, the boom in private consumption seen was not attributable to high expectations of future tax cuts, but to cyclical and real factors.

108. Fischer (2000, p. 103).

109. Ball and Mankiw (1995); Buiter and Kletzer (1992).

110. Posen (1998, chapter 3) makes this argument informally, applying Ball and Mankiw's (1995) "debt fairy" parable to Japan, and adding the parable of the dry rice paddy (a prospect of global warming making today's rice paddy tomorrow's desert does not imply that one should not use the water in the local reservoir to respond to this year's drought). 
tion effects. ${ }^{111}$ It is important to note, however, that regardless of how they were presented at the time, most tax changes in Japan over the past two decades were later wholly or partially reversed, and even one-time public works projects have consistently led to sustained spending increases. A highly refined microlevel analysis, taking into account the specific structure of the tax cuts, will be required to fully sort out the effects of temporary versus permanent changes in fiscal policy.

\section{The Real Effects of Financial Crises}

Strictly speaking, financial regulation and supervision are not part of macroeconomic policy. This is because they are in some sense supplyside issues, unlikely to be resolved by increased demand; in fact, part of the reason why financial sector problems arise is that regulators usually wait to see whether a return to growth will solve them, and instead they get worse. Yet since Bernanke's 1983 article, and as illustrated by the 1997-98 Asian financial crises - not least the one in Japan—financial system problems have been viewed as special among structural concerns because they have macroeconomic implications beyond their direct employment contribution to GDP. Particularly for monetary policy, but also for the question of whether investment can return, it is important to take these problems into account. The destruction of firm-specific information capital as well as problems of transition and the regulatory difficulties of getting new bankers in place means that one cannot simply ignore this issue in Japan.

Much has been made in this and in earlier, more favorable contexts of the distinctiveness of the Japanese bank-centered system. ${ }^{12}$ Cross shareholdings, management ties, patient long-term capital, the relative absence of securities markets and venture capital, collateralized lending, debtholders' primacy in bankruptcy hearings-all these were supposed to be different and were supposed to be good. Yet for all the supposed distinctiveness of the Japanese financial system, the two factors of slow deregulation and erosion of bank capital suffice to explain just about the entire course of credit developments over this period. These are the same two factors that, by consensus, explain most of the course of events in the

111. Carroll (2000) hooks a theoretical analysis of broader issues about saving behavior on these stylized facts.

112. Fukao (1995); Aoki and Patrick (1994); Hoshi and Kashyap (2001). 
U.S. savings and loan crisis. The importance of these microeconomic incentives in determining bank behavior is why demand management policy alone is not enough to resolve the problems of the banking system.

The postwar Japanese financial system traditionally featured indirect financing of industry, with a concentrated banking sector and underdeveloped capital markets. ${ }^{113}$ As in the United States prior to deregulation, there was compartmentalization between securities and banking activities, because the occupying authorities imposed a law modeled on the GlassSteagall Act. Also as in the United States, interest rates on deposits were regulated, but they were capped at much lower levels relative to lending rates and to returns on capital, in a conscious effort to subsidize investment. The Japanese banks competed for depositors with the postal savings system, which took in two-thirds as much in deposits as the entire commercial banking sector. Since postal savings funds were made available to the government for use in the FILP, as well as other uses, postal savings accounts offered a slightly higher rate of interest as well as an implicitly superior government guarantee.

Until the 1980s Japan imposed strong limits on corporate finance in return for the lower cost of funds. Much capital was administratively allocated by the Ministry of Finance, the Ministry of International Trade and Industry, and other agencies, through the banks, because demand exceeded supply. ${ }^{114}$ Only NTT (the telephone monopoly), the national rail system (also government owned), and the electric utilities were encouraged to issue corporate bonds. All other private firms had to put up private collateral with a trust bank and then pay a securities firm for the privilege of selling a bond. The long-term credit banks provided most of the long-term lending for industry, along with the main banks in their web of relationships with borrower firms. Unlike in the United States, where the separation between the banking and securities businesses arguably was a spur to financial innovation, in Japan the Ministry of Finance limited financial innovation. ${ }^{115}$

113. See Ogata (1996) for a timeline. Hoshi and Kashyap (2001) make a provocative historical argument that many of these attributes, and the whole keiretsu-main bank system in Japan, were a recent and partly American creation, not characteristic of Japan.

114. Vogel (1996).

115. Steil (1995) documents and describes in detail the stifling effect of regulatory power on financial competition and development in Japan until the big bang of the late 1990s. 
That ministry's view of financial stability meant controlling exit as well as entry to the financial market, and in doing so the regulators took a limited view of disclosure, clearly associating market competition with unnecessary risk. ${ }^{116}$ As one example, deposit insurance was kept informal, without any specified limits, because the real objective was never to have any banks fail, and so no deterrent effect on savers was desired. The presumption on all financial activity, whether large transactions, going into new business areas, or introducing a new financial product, was that it was subject to approval from the regulators, which was often denied.

Yet the same economic forces working on U.S. banks in the 1970s and 1980s were also at work on the Japanese financial system, albeit more slowly. As Shujiro Ogata notes, beginning in the mid-1960s there were growing capital markets, growing government bond markets, diversification of the available savings instruments, a gradual erosion of compartmentalization, and, starting in 1985, a phased deregulation of deposit interest rates. ${ }^{117}$ Japan's persistent balance of payments surplus made capital controls less relevant, and economic development made easy lending harder to come by. By the mid-1980s the same process that had hit the American savings and loans and small banks had begun in Japan. Japan's small banks were at least as ill prepared as their U.S. counterparts to adapt their credit assessment practices, and they had even fewer options for shrinking or changing their business lines.

This dynamic underlies what has emerged as the consensus view of the source of the Japanese banking problem. ${ }^{118}$ The best Japanese nonfinancial firms were going directly to the capital markets, whether at home or abroad, and were driving down margins on banks' lending and demanding cheaper capital. When, for example, the commercial paper market was created in 1988, $¥ 2.2$ trillion was issued in the first year, and an average of around $¥ 9$ trillion a year was issued in the 1990s. In 1989 and 1990, literally no domestic yen bonds were issued by any firms other than NTT or the electric utilities, because all other corporate borrowers had gone to the Euroyen markets. Meanwhile, in 1985-86 alone, $¥ 150$ trillion went

116. Steil (1995); Vogel (1996).

117. Ogata (1996).

118. Ueda (2000), Hoshi and Kashyap (1999), Cargill, Hutchison, and Ito (2000), and Mikitani and Posen (2000) give overlapping accounts of how overbanking and regulatory forbearance under deregulation caused banking problems in Japan akin to the U.S. savings and loan crisis. 
into high-yielding ten-year time deposit accounts in the postal savings system. Banks were getting squeezed on both sides of their margins.

So, just as their American counterparts did, the Japanese banks ramped up lending to small and medium-size enterprises (SMEs) on the basis of real estate collateral, feeding into a property boom. As Yoshinori Shimizu carefully documents, up until 1983, total bank lending to SMEs in Japan was about equivalent to total lending to large firms. ${ }^{119}$ SME lending then began to rise and continued to rise for the remainder of the decade, reaching a level three times that of lending to larger firms by 1990 . With the finance ministry committed to no exit from the financial markets, and with banks still holding a large amount of loanable funds, banks had to chase after new areas for lending. The three long-term credit banks made the biggest shift in lending toward SMEs and real estate, since as the providers of long-term loans to the biggest corporations they had suffered the sharpest falloff in lending business. This helps explain the disproportionate tightening in banks' "lending attitude" over this period as reported by large firms (as measured by the Bank of Japan's tankan survey), shown in figure 10 .

The collapse of the Japanese stock market in 1990 and again in 1992, followed by steady declines in land prices, triggered the financial crisis with which Japan is still coping today. Underlying the collapse, however, was the inherent problem of deregulating financial markets only partially, allowing banks neither to change their business lines nor to close, while their old margins and their old methods of credit evaluation eroded. Bank supervisors at the finance ministry refrained from closing banks, in hopes that a pickup in the economy would bail them out. ${ }^{120}$ Japanese bank regulators still believed that stability was defined as no bank failures. Meanwhile the banks, responding to the moral hazard of having too little capital and too much deposit insurance, rolled over outstanding bad loans rather than write them off, and they continued to lend on real estate collateral well into the 1990s.

The jūsen, private nonbank financial firms dedicated to mortgage and real estate lending, were the first large institutions to visibly collapse under the cycle of bad loans, depreciating collateral values, and credit contraction, feeding further local SME business collapses and bad loans.

119. Shimizu (2000).

120. Kanaya and Woo (2000), Lincoln (1998), and Bergsten, Ito, and Noland (2001, chapter 3) all discuss the extent and effects of regulatory forbearance. 
Figure 10. Tankan Survey of Banks' Lending Attitude, by Size of Borrower, 1982-2001

Diffusion index ${ }^{\mathrm{a}}$

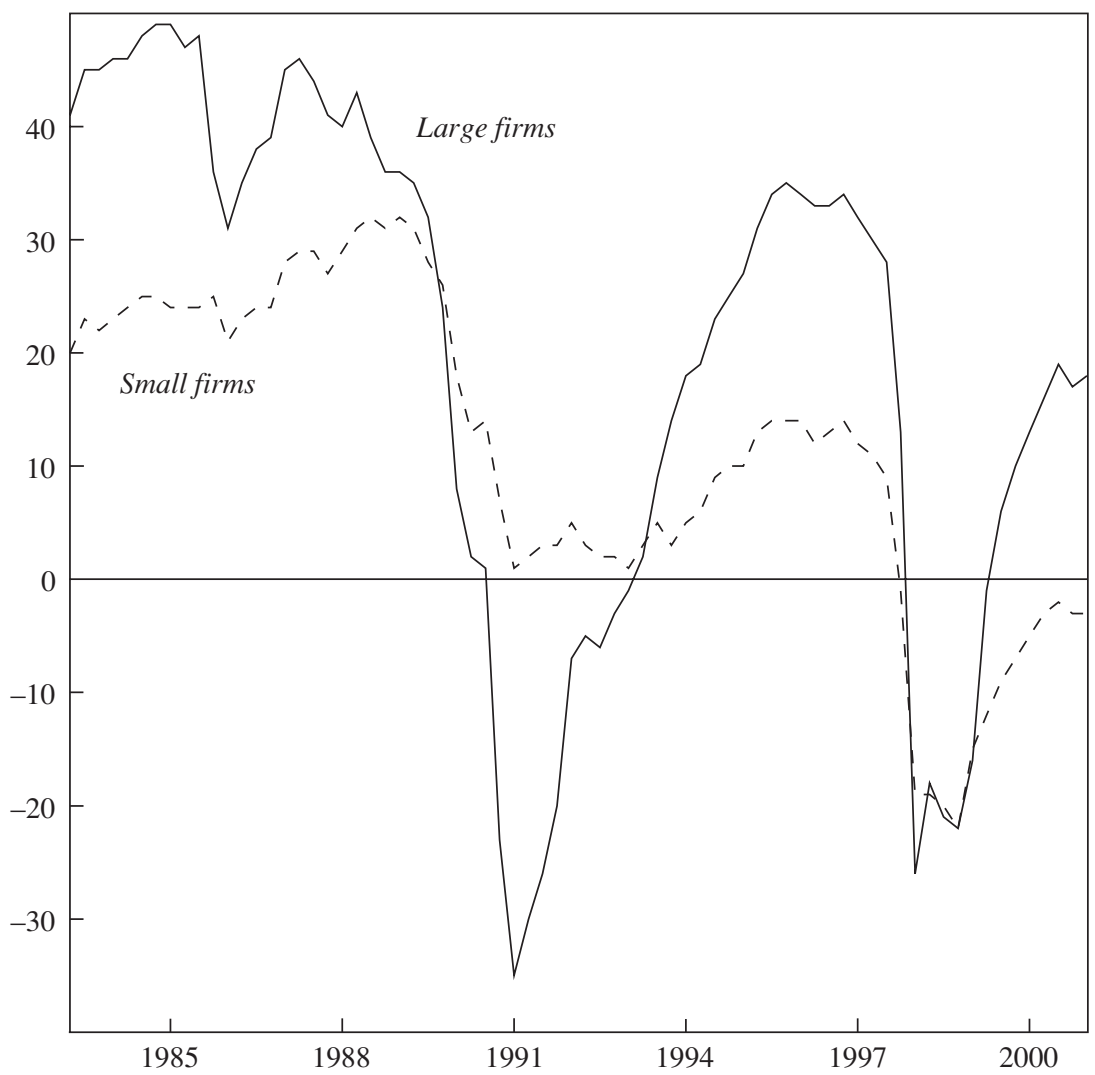

Source: Bank of Japan's tankan survey.

a. Percent of respondents reporting an "accommodative" attitude minus that reporting a "severe" attitude.

Ministry of Finance inspectors admitted in 1991 that 40 percent of the jüsen's outstanding loans were nonperforming but gave them a ten-year regulatory window to deal with the problem. Four years later, the share of nonperforming loans on the $j \bar{u} s e n$ 's only slightly smaller balance sheets had risen to 75 percent. Thomas Cargill, Hutchison, and Takatoshi Ito put it very well:

The resolution of the jusen industry [in 1995] was fundamentally flawed and illustrated to the market the government's unwillingness to objectively assess 
and manage the financial crisis. It illustrated that the convoy system was still operational by imposing the greater part of the resolution burden on the banking system. ... The intense public negative reaction to the small amount of taxpayer funding included in the plan gave the regulatory authorities the rationale to continue a policy of forgiveness and forbearance. . . . As a result, the government became very reluctant to propose the use of public funds to resolve the financial distress. This reluctance to use public funds further delayed resolution of the nonperforming loan problem and thereby substantially increased the ultimate resolution costs. ${ }^{121}$

The difference between the U.S. regulators' response to the 1980s savings and loan crisis, also based on real estate lending, and the Japanese regulators' initial response to their crisis was only in degree, not in kind, but the difference in degree was enormous. Whereas the American regulators, with prompting from legislators, tackled the problem within five years of its beginning, and at a cost of 3 percent of GDP, Japan is now into its eleventh year of financial fragility, and the expected cost to the taxpayer is on the order of $¥ 100$ trillion, or 20 percent of GDP (we return below to the question of what is the right valuation of the nonperforming loans).

As in the United States, much of Japanese securities deregulation proceeded down an independent track, neither impeded nor hurried by the country's banking crisis. In November 1996, then-Prime Minister Ryutaro Hashimoto announced his plan for a "big bang" deregulation of financial markets, promising a series of deregulatory initiatives through 2001. These included allowing price competition on brokerage commissions and other financial fees, removal of limits on individuals holding bank accounts abroad or trading foreign currencies, removal of restrictions on the trading of derivatives, and allowing competition among banks, securities houses, and insurance companies. Given the implementation lags for any deregulation initiative, it is difficult to say as yet what the state of the Japanese financial system will be once the banking crisis is resolved. ${ }^{122}$

121. Cargill, Hutchison, and Ito (2000, p. 53). The convoy system was Japan's explicit policy during the 1990s of forcing healthier financial institutions to bail out or take over weaker ones, so that no bank would fail outright.

122. See OECD Economic Surveys: Japan, 1996-2001; these surveys do an excellent job of tracking in detail the proposals and progress of deregulation in Japan. Also, Gibson (1997) gives an interesting critical interpretation of the relevance of the big bang to Japanese economic performance. 
Between the surprise failures of Yamaichi Securities, the fourth-largest Japanese securities firm, and Hokkaido Takushoku Bank, a major bank based on the north island, in the autumn of 1997 and the passage of a package of bank reform legislation a year later, Japan teetered on the edge of outright financial crisis. ${ }^{123}$ Japanese banks were at first increasingly penalized and then shut out of interbank overnight markets; stock prices tumbled below 12,000 on the Nikkei-225; private savers shifted their money out of bank accounts into the postal savings system and increasingly into cash; and the yen fell rapidly against the dollar, until joint intervention and the prospect of a change in government halted the slide in June 1998.

With the coming of the government of Prime Minister Keizo Obuchi in July 1998, following a setback for the Liberal Democratic Party in an upper house election, some real financial reforms were put in place. ${ }^{124}$ In a bill passed in October 1998, the government began to address the recapitalization of the Japanese banking system with public funds. In addition to a new commitment to stricter supervision, the government arranged for all but one of the largest banks, and most of the second-tier banks, to take strictly conditional capital injections, based on new balance sheet inspections. ${ }^{125}$ The Japanese government received in return preferred shares that would allow the regulators to take over the bank or vote management out if the mandated capital adequacy ratio was not met. On April 1, 1999, $¥ 7.5$ trillion was injected into the banking system, with every major bank except Bank of Tokyo-Mitsubishi receiving funds. Over the months that followed, the Japan premium in interbank markets disappeared, some savings shifted back into bank accounts, and the bigger Japanese banks cut back on their rolling over of loans. The nationalizations of the bankrupt Long Term Credit Bank and Nippon Credit Bank in the fall of 1998 demonstrated the resolve of the new Financial Supervision Agency (FSA). ${ }^{126}$ Since that time, Japan's financial sector has

123. Posen (1998, chapter 4) describes the situation and its dynamics at the time.

124. An earlier capital injection effort in March 1998 foundered for lack of adequate supervision and accounting. See Peek and Rosengren (2000) and Bergsten, Ito, and Noland (2001).

125. Posen (2000a).

126. The toughening of loan standards was limited, however, to those banks truly under regulatory scrutiny and sufficiently recapitalized. Hence the fixation upon the behavior of Shinsei Bank, the former Long Term Credit Bank, which had been sold to American investors, and its willingness to cut off delinquent borrowers such as Sogo Department Stores. As theory would predict, those banks that were not recapitalized continue to roll over outstanding loans rather than take the write-offs. 
remained fragile, continuing to accumulate bad loans and in general making no profits, yet little has been done in the way of forced consolidation or recapitalization. ${ }^{127}$

There are many reasons to be concerned with Japan's ongoing financial sector problems. One is their potential to lead to a misallocation of resources, as banks continue to throw good money after bad. Another is that the large number of financial firms with inadequate capital leaves Japan vulnerable to a repeat of the near collapse of 1997-98, or worse, with significant international spillovers likely. ${ }^{128}$

For purposes of this paper, however, we focus on the impact of the Japanese financial crisis on aggregate demand. The belief that banking sector fragility can have macroeconomic effects goes back a long way. As shown above, conditions in the banking system can have potentially important effects on the transmission of policy through conventional monetary channels: for example, by affecting the currency-to-deposits ratio, or banks' willingness to lend excess reserves. These are major themes of Friedman and Schwartz, ${ }^{129}$ and similar observations apply to the Great Recession. Besides its monetary impact, banking system stress may also have had nonmonetary effects, by reducing the availability of intermediated credit for borrowers (usually SMEs) who rely on banking relationships to surmount problems of imperfect information. In a seminal paper, Bernanke explored this hypothesis for the Great Depression in the United States, using the deposits of failed banks as a proxy for financial system stress; his results demonstrated that bank closures had an independent negative effect on investment, beyond that predicted by movements in money and interest rates, due to the destruction of informational capital when the banks closed. ${ }^{130}$ This played a key role in propagating the asset price and monetary policy shocks that started the Great Depression. ${ }^{131}$

Bernanke and Cara Lown extended this insight to regional differences in lending in the United States at the end of the 1980s after the bust in real estate and the savings and loan crisis. ${ }^{132}$ They found that differences in bank capital explained regional differences in the growth or contraction

127. Fukao (2001).

128. Posen (2001b).

129. Friedman and Schwartz (1963).

130. Bernanke (1983).

131. Bernanke (1995).

132. Bernanke and Lown (1991). 
of bank lending, particularly for SMEs. Related to this is the extensive research done on the existence of a "bank credit channel" for monetary policy. ${ }^{133}$ This has broken into two questions: whether monetary policy affects bank lending, and whether that impact is large, given alternative sources of capital. The key issue in answering the second question is whether instances of declining investment reflect declining loan supply (due to the effects on banks) or declining loan demand (because of the common shock affecting banks and nonbanks). ${ }^{134}$ Although the theory is largely agreed upon, still at issue is some estimate of the size of the macroeconomic effect of bank problems.

A number of researchers have examined investment in Japan from this perspective in recent years. Several have shown that lending was constrained by demand rather than supply in the early 1990s. Nobuhiro Kiyotaki and Kenneth West set a baseline clearly showing an effect of the asset price collapse on Japanese business fixed investment, in line with the credit cycles view of Kiyotaki and John Moore. ${ }^{135}$ In so doing, they strongly implied that, through the end of their (aggregate) data, contractions of Japanese investment were explicable as a decline in investment demand, with no need to invoke bank effects. Similarly, Robert Chirinko and Huntley Schaller find, as do Vidhan Goyal and Takeshi Yamada, a bubble in Japan in the 1980s, with investment responding to stock market prices without reference to banks at all. ${ }^{136}$ David Woo finds support for a credit crunch only in 1997, at the height of Japan's financial difficulties, and ample lending available for most of the 1990s. ${ }^{137}$

Other researchers have found some indications consistent with the existence of a credit channel in Japan but were unable to assess its effects during much of the period. Kazuo Ogawa and Shin-ichi Kitasaka show evidence that expenditure on fixed investment was much more sensitive to bank loans for small firms than for large firms in Japan from 1976 to 1995, consistent with the existence of a lending channel. ${ }^{138}$ Eunkyung Kwon estimates a standard monetary model (but including land prices),

133. See also Bernanke and Gertler (1990), Gertler and Gilchrist (1994), Kashyap and Stein (1995, 2000), and Morgan (1998).

134. Peek, Rosengren, and Tootell (2000) attempt to address these issues in a U.S. context, using measures of regulatory pressure to isolate loan supply shocks.

135. Kiyotaki and West (1996); Kiyotaki and Moore (1997).

136. Chirinko and Shaller (2001); Goyal and Yamada (2000).

137. Woo (1999).

138. Ogawa and Kitasaka (2000). 
which shows a larger than expected effect of monetary policy on the Japanese economy during 1964-93, which he attributes to the use of land as collateral. ${ }^{139}$ Jun-Koo Kang and René Stulz show that listed firms whose debt had a higher fraction of bank loans in 1989 performed worse and invested less during 1990-93, and were vulnerable to bank shocks during the negotiations over the Basle capital accords. ${ }^{140}$ Tamim Bayoumi, using a VAR framework including fiscal policy, monetary policy, domestic asset prices, and bank loans, concludes that financial intermediation difficulties magnified the impact of asset prices on the Japanese economy. ${ }^{141}$ Tomoya Suzuki includes a survey-based measure of the price of bank loans to try to identify credit supply effects in a similar VAR, and finds that they amplify the effect of monetary policy shocks. ${ }^{142}$ Michael Gibson, however, working with firm-level data, finds that the financial health of listed firms' main banks did not significantly affect their investment behavior. ${ }^{143}$ In summary, to our knowledge, the paper by Woo is the only one to look directly at the effects of banking fragility on investment in Japan over the course of the recession, and it does so solely with microdata.

Japan's Great Recession, however, allows us to examine the macroeconomic impact of banking problems with some interesting twists. Unlike much of the credit channel literature, we can focus solely on banking fragility effects, because monetary policy was tending in an accommodative direction or was ineffective after the initial bursting of Japan's bubble (remember the excess reserves discussed earlier). The Japanese financial crisis has gone on sufficiently long to allow us to make use of time-series variation in asset markets as well as in the macroeconomic fundamentals; we are not limited to one event or shock that might well be coincident with other factors. In contrast to Bernanke, therefore, we are analyzing the effects of ongoing financial fragility rather than large numbers of bank failures, a more relevant situation for most developed economies today.

139. Kwon (1998).

140. Kang and Stulz (2000).

141. Bayoumi (2001).

142. Suzuki (2001).

143. Gibson (1997). In a series of thoughtful papers, Peek and Rosengren $(1997,1998)$ examine the effect of stock market and bank shocks in Japan on lending abroad, finding evidence in support of a bank channel, but do not deal directly with the impact on the Japanese economy. 
The relative lack of failures does not, however, mean that the banking system has continued to function smoothly. Our view is that it is not failures per se that disrupt the supply of intermediated credit; rather it is banking system stress, regardless of whether that stress leads to outright failures. Clearly, the state of the economy, of interest rates, and of asset prices are all sources of stress for banks, but ones that will be shared with the banks' borrowers. Bank capital, as examined by Bernanke and Lown and by Glenn Hubbard, Kuttner, and Darius Palia, ${ }^{144}$ is a more direct link to bank stress, assuming that capital standards are adequately enforced with appropriate supervision. ${ }^{145}$

In this context the threat of an imminent regulatory tightening to enforce the capital standards should have the same effects on forwardlooking financial markets as one actually implemented: as the likelihood of that tightening recedes, the alternative incentive for undercapitalized banks to gamble on resurrection should predominate, and lending should become easier. Increased market discipline in the form of pressure in the interbank market or of increased scrutiny from depositors-as well as bank stock prices-also should have an independent effect on bank stress, to the extent that these counterparties react to more information than is captured in asset prices and macroeconomic conditions.

Of course, nonperforming loans and write-offs, and the resulting measures of bank capital, would be the most direct measures of bank stress, provided supervision is adequate. In Japan in the last decade, however, measurement of bad loans has been a source of constant dispute, and measurement of bank capital has been even more difficult. ${ }^{146}$ In the most infamous example, in June 1998 Long Term Credit Bank was said to have a more-than-adequate capital ratio, along Basle principles, of 10.4 percent, only to go bankrupt and be nationalized a few months later. On current official FSA accounting, an estimated $¥ 151$ trillion in loans are classified as category 2, 3, or 4 (meaning under watch, behind in payment, or to a bankrupt company, respectively); collectible capital on these loans amounts to $¥ 70$ trillion. A range of unofficial estimates of the worst two categories of loans alone runs from $¥ 40$ trillion to $¥ 80$ trillion, and rea-

144. Bernanke and Lown (1991); Hubbard, Kuttner, and Palia (forthcoming).

145. As shown in Van den Heuvel (2001), even the threat of future enforcement of a capital requirement can have an impact on current lending.

146. See IMF (2000), Bergsten, Ito, and Noland (2001, chapter 3), and Fukao (2001) for discussions of the various estimates of bad loans and bank capital. 
sonable estimates of the recoverability of category 2 loans put expected losses there at another $¥ 40$ trillion or more. ${ }^{147}$ Leaving aside, as beyond the scope of this paper, the enormously important question of whether or not the Japanese banks can survive such losses, we merely wish to underline that no reliable data series of nonperforming loans or of Japanese bank capital exist for use in econometric investigations. ${ }^{148}$

We investigate the hypothesis that nonmonetary bank effects were sizable in Japan by estimating a set of equations relating bank lending (real loan growth or "lending attitude," as measured by the tankan survey) and investment to macroeconomic factors affecting loan demand (inflation, output, and interest rates) and, in the spirit of Bernanke, ${ }^{149}$ proxies intended to capture the degree of stress being experienced by the banking system (given that meaningful data on nonperforming loans are not available). Most of the regressions use the real change in the price of commercial real estate for six major cities in Japan as such a proxy, reflecting the change in the value of the collateral used for a large portion of banks' assets. The real change in the index of bank stock prices from the Tokyo Stock Exchange is used as an alternative proxy. Plots of both of these variables appear in figure 11. The regressions using the property price proxy are estimated from semiannual data from 1976 through the first half of 2000; the starting date is 1983 for the regression using bank stock prices.

We also wish to assess the effects on lending of the regulatory environment and measures of financial stress other than asset values. Drawing on the brief history given at the start of this section, we therefore try two dummy variables in succession. The first is set to unity from the first half of 1998 through the first half of 1999. This was a period of stepped-up market discipline in the form of private savers taking their money out of the

147. Gillian Tett, "Loans Conundrum Requires a Touch of the Houdinis," Financial Times, May 4, 2001, p. 2. A recent report by David Atkinson of Goldman Sachs, Tokyo, claims that loans to virtually bankrupt firms alone total $¥ 170$ trillion, based on the ability of borrowers to repay principal rather than just roll over interest payments (reported in Andrew Cornell, "Bank Shares Hit by Bad-Debt Alert," Australian Financial Review, August 30, 2001, p. 8.

148. Here the parallel to the U.S. experience in the Great Depression, as documented by Friedman and Schwartz (1963, p. 330), is worth noting: "One important factor was the drastically weakened capital position of the commercial banks, which made them extremely vulnerable to even minor drains. The recorded capital figures were widely recognized as overstating the available capital, because assets were being carried on the books at a value higher than their market value."

149. Bernanke (1983). 
Figure 11. Measures of Real Estate and Bank Stock Prices, 1969-2001

\section{Real estate prices}

Index, March $1990=100$

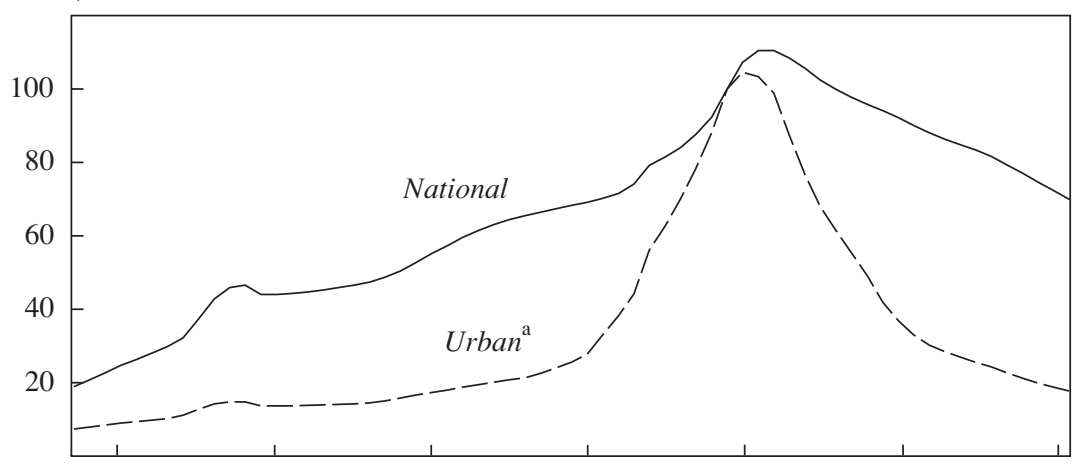

Stock prices

Index

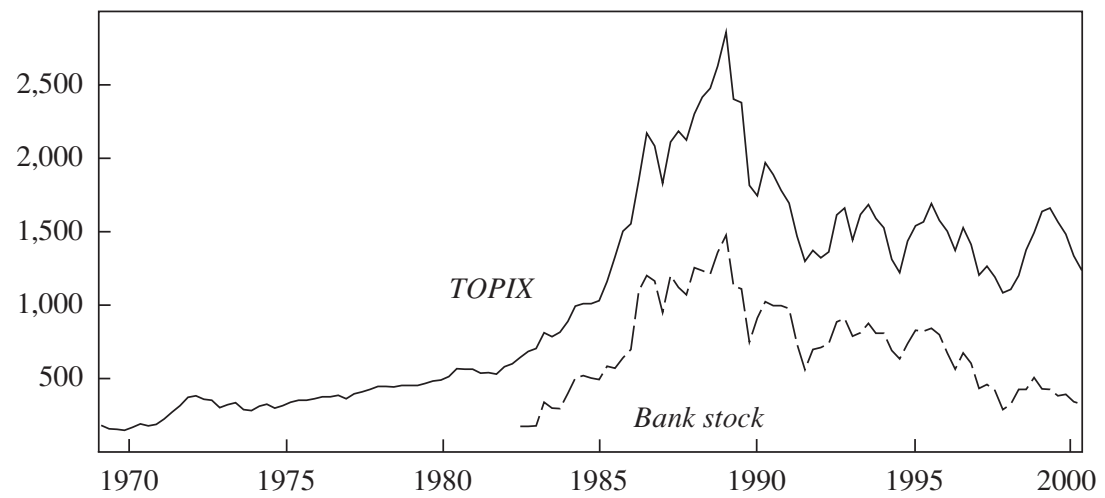

Sources: Japan Real Estate Institute and the Tokyo Stock Exchange.

a. Price in six major industrial cities.

commercial banking system in favor of postal savings accounts and cash. It also was the time of the so-called Japan premium: the difference between the interest rate on overnight borrowing paid by Japanese banks and that paid by other banks in international markets. ${ }^{150}$ This period coincides

150. A more precise dating would run from the surprise closure of Hokkaido Takushoku Bank in November 1997 through the capital injection at the end of March 1999. Our reliance on semiannual data on real estate prices requires the coarser dating used here. 
almost perfectly with a sharp deterioration in the tankan lending attitude measure (figure 10). The second dummy variable is set to unity from the first half of 1998 through 2000 (the end of the sample), reflecting a period of heightened regulatory scrutiny from the time the Obuchi government took office, set up the FSA, nationalized the Long Term Credit Bank and the Nippon Credit Bank, and completed the capital injection described above.

The bank stress proxies are significant, both economically and statistically, regardless of which lending and stress measures are used. In the baseline regression reported in column 6-1 of table 6, which uses real loan growth for the "city" banks (a group of nationwide commercial banks) as a measure of bank lending, the estimated coefficient on the property price of 0.16 means that, ceteris paribus, the 20 to 30 percent annual declines in commercial real estate prices from 1992 through 1995 would have reduced loan growth by 3 to $4 \frac{1}{2}$ percent. Given the magnitude of the estimated interest rate coefficients, this reduction is roughly equivalent to a 3-percentage-point rise in the interest rate. Similar results are obtained for lending by the regional banks (column 6-2), although with a somewhat smaller coefficient on property prices.

Bank stock prices are also a significant predictor of lending by the city banks, as shown by the results reported in column 6-3. The coefficient on the bank stock price is much smaller, but only because the swings in stock prices are much larger than they are for real estate prices. The magnitude of the estimated impact is in fact comparable to those from the property price regressions: the coefficient of 0.03 , combined with the sharp decline in bank stock prices in the first half of 1992 (an annualized log difference of 100 percent), translates into a 3 percent real decline in lending.

The results also indicate that bank lending was further depressed during the market discipline episode, as shown by the significant negative coefficient on the 1998-99 dummy variable in the baseline regression in column 6-1. The results are, however, weaker for the regional banks and in the regression using bank stock prices, perhaps because the "market discipline effect" is incorporated into the stock price. By contrast, the coefficient on the supervisory improvement dummy is small and not statistically significant when included in the regression, as shown in column 6-4. This finding supports the contention that the current supervisory regime, after the April 1999 capital injection, is actually lax for many banks. ${ }^{151}$

151. Fukao (2001); Posen (2001a); Peek and Rosengren (2001). 


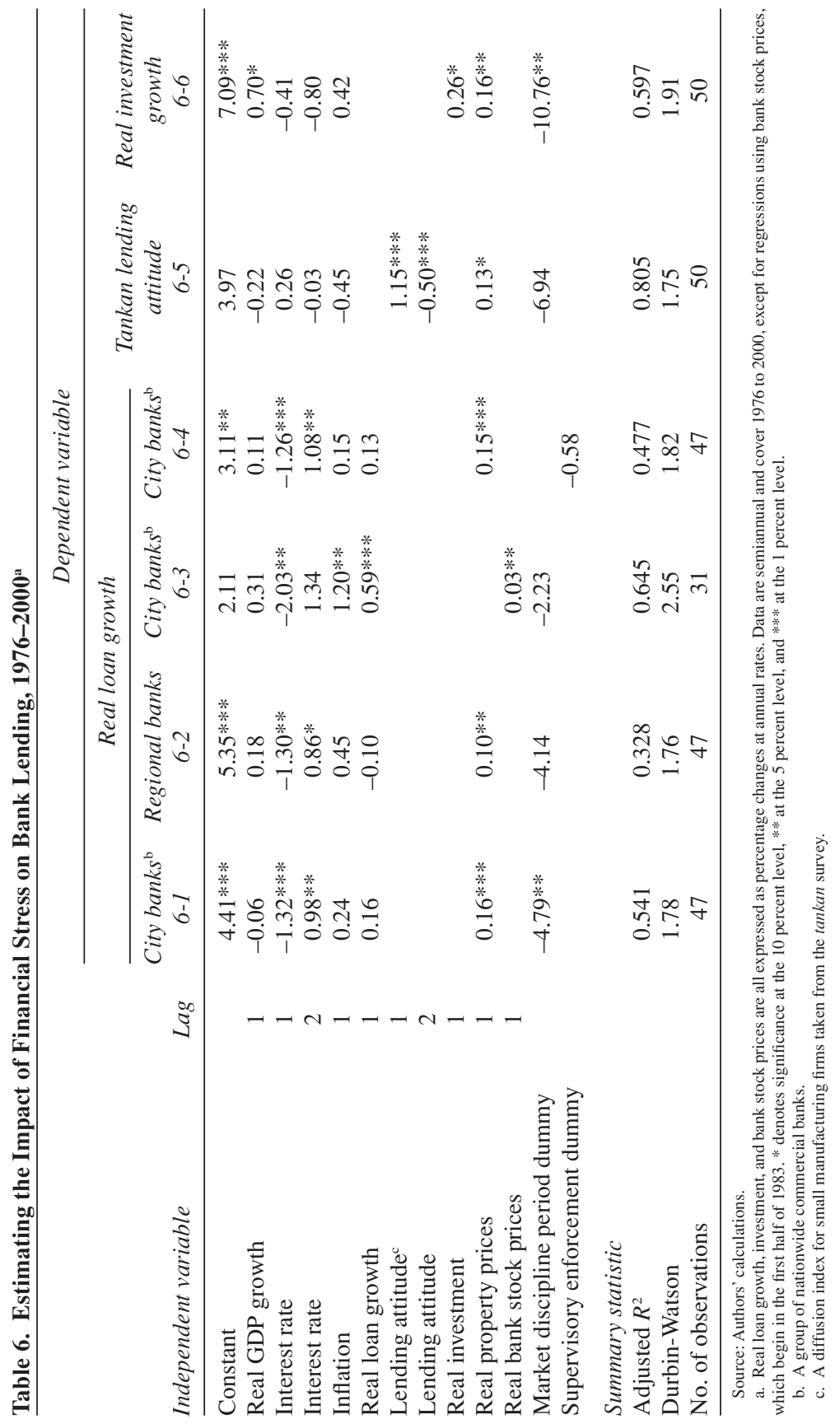


There is, of course, some danger that these regressions are picking up in part the effect of a decline in loan demand. The inclusion of macroeconomic conditions such as GDP growth should, in principle, control for changes in the demand for credit. (The results are also robust to the inclusion of other controls for the investment climate, such as the tankan survey of business conditions.) Although banks had the largest exposure to real estate losses, many nonfinancial firms had also invested in real estate, and a few held bank shares, and consequently the decline in asset values surely affected these firms as well. And to the extent that a deterioration in the value of nonfinancial firms' collateral impaired their ability to borrow, that, too, would reduce bank lending. The results may therefore be supportive of an operative "broad" credit channel as well.

To determine the extent to which the results are driven by bank loan supply, column 6-5 in table 6 reports the results of a regression in which the dependent variable is the tankan index of lending attitude for small manufacturing firms - arguably a relatively pure proxy for bank loan supply. Although the estimate is somewhat less precise (the estimated coefficient is significant at only the 10 percent level), the large negative coefficient points to a distinct effect on bank loan supply. Finally, column 6-6 demonstrates that banking stress is associated with a significant decline in real investment activity.

To summarize: the weak condition of the banking sector during Japan's Great Recession-in particular, the decline in collateral values and in bank stocks - has depressed bank lending above and beyond any impact of monetary policy or general macroeconomic conditions, much in the way that Bernanke demonstrated for the United States in the 1930s. And given that Japanese firms rely heavily on bank finance, much as firms did in the prewar United States, it is highly likely that this decline has had real effects. What distinguishes the Japanese case from the Great Depression is that Japan's experience shows that the effects of financial distress cannot be avoided solely through forbearance. The fact that banks were kept open prevented neither ongoing contractions in lending as asset prices reflected illiquid land markets for distressed collateral, nor an acute additional cutback in lending when financial fragility became apparent to savers and interbank markets. Market discipline is always present with a banking system, even in Japan with its notoriously risk-averse savers and stock market cross-shareholdings. As others have argued, ${ }^{152}$ regulation only matters

152. Van den Heuvel (2001); Peek and Rosengren (2001). 
when it credibly is or will be with you, and it will have a contractionary effect once banks are undercapitalized, but only to the extent that it is truly enforced.

\section{What Can Macroeconomic Policymakers Learn from the Japanese Experience?}

Sometimes it is more important to test the solidity of the ground on which one has built than to break new ground. It was with this intent that we undertook the investigations in this paper. In the broader world, if not among academic economists, the list of recommendations for expansionary monetary policy, stabilization policy, and financial reform offered by mainstream macroeconomists for Japan during the last ten years has set up Japan as a critical test case for such prescriptions. Japan's apparent inability to escape from its Great Recession has added to the skeptical view that macroeconomic policies did not work as they were supposed to, and has given rise to disputes in both the monetary and the fiscal realm over whether or not expansionary policies actually were being pursued. In addition, Japan's status as the developed economy with the most distinctive institutional framework, and the extreme resistance of that framework to pressures for change, add to the attraction of assessing the effects of macroeconomic policy in a context that is extreme but as little subject to the Lucas critique as possible.

Our results indicate that the macroeconomic synthesis underlying the policy recommendations made by mainstream economists to the Japanese government in recent years is indeed built on solid ground. The general message for Japan's policymakers is that, even in these extreme circumstances, the old toolkit of countercyclical macroeconomic policy, abetted by due concern for the special role of the financial sector, remains relevant. What looks and feels like a recession, with falling inflation and rising output gaps, is a recession, and recessions are harmful to the allocation of resources as well as wasteful of opportunities for growth. Monetary policy should take great pains to avoid deflation and the zero nominal interest rate bound, and the best way to do so is to put aside fears of accelerating inflation when inflation is low. It is all too easy, in fact, to build in inertial low inflation, many of the concerns of the 1980s and early 1990s notwithstanding. When an economy is caught in a liquidity trap, the only choices 
for central banks are large and lasting quantitative measures, or the accommodation of fiscal expansion, or both.

Japan's experience also shows that fiscal policy works pretty much the way Keynes suggested it does: contractions are contractionary and expansions expansionary, and even wasteful public spending has a clear multiplier (although it is disadvantageous in other ways). The structure and distribution of the tax burden do matter, however, and tax cuts targeted to the more liquidity constrained are likely to have larger effects. Ricardian equivalence effects, even in Japan, are not sufficiently large to be relevant to fiscal policy, so that sustainability concerns can be addressed separately from stabilization concerns. Financial fragility does have significant nonmonetary effects on aggregate output, and keeping undercapitalized banks open through regulatory forbearance or forced loan rollovers does not significantly mitigate those costs (although it does add to the eventual bill).

This assessment of the effectiveness of macroeconomic policy in Japan in the 1990s does not directly address the question of why the Great Recession occurred and why it has lasted so long. Given our estimates of the effects of deflationary inertia, fiscal contraction, and financial fragility, it is reasonable to conclude that macroeconomic policy actions (and inactions) played a major role. Although we do not offer a decomposition here because of our focus on lessons from Japan, clearly these effects on their own are large enough to account for much of the output gap. Most economists would agree that some combination of asset price declines, financial fragility, policy mistakes, and external demand shocks underlies Japan's Great Recession; they differ only in the relative weights to be assigned to these factors.

It is here that the analogy to the world depression of the 1930s becomes most revealing. Although, of course, there is no comparison between them in the degree of lost output, deflation, unemployment, or human misery, as economic phenomena the two episodes run along similar lines. Debt-deflation in both cases was exacerbated by an inability or unwillingness of policymakers to abandon an extreme commitment to price stability; bank panics and the destruction of relationship-specific information transmitted financial shocks; and real wages failed to fall sufficiently to make up for the decline in asset prices and profitability. And the different, far milder experience of Japan's Great Recession is in part due to the lessons that were learned and the institutions that were put in place after the Great Depression: deposit insurance, to limit bank panics; 
an open world trading system and flexible exchange rates, to allow stagnating economies to resume growth through trade; automatic stabilizers (although these remain smaller in Japan than in other developed countries), to put some limit on the tendency toward excessive thrift; and some use of discretionary fiscal stimulus, to put a floor underneath adverse developments.

All this also points to some lessons of policy guidance for Japan today, as well as for other large economies at risk of deepening recession from a combination of asset price declines and external shocks. First and foremost, our results encourage a positive view of active countercyclical policy, particular on the monetary side: the inflationary risks of quantitative easing appear to be nonexistent, precisely because it is extremely difficult for the central bank to raise inflation expectations when nominal shortterm interest rates are close to or at zero. Second, our analysis indicates that discretionary fiscal policy can get the maximum bang for the yen by increasing the average household's disposable income, and by recognizing that the budget deficit alone is not an adequate measure of fiscal stimulus. ${ }^{153}$ Third, our finding of a limited Ricardian offset by savers even under the extreme circumstances of Japan in the 1990s underlines that monetary accommodation of fiscal expansion can be the optimal response, rather than something generically to be avoided. Fourth, we find that the microefficiency arguments for resolving nonperforming loan problems quickly are strongly reinforced by the macroeconomic evidence of credit crunch effects, and occasional disintermediation, even when banks are kept open.

Two major issues that this paper has raised but not directly addressed should be examined before we become too comfortable with these results. One is the question of whether greater international integration would have done Japan more harm than good during this period, at least from the perspective of macroeconomic performance. The other is, What is it about the Japanese political economy that explains the policy choices made? On the issue of openness, recent developments in the new open economy

153. An interesting question for future research is whether the response of households to the size of a fiscal stimulus is nonlinear, that is, whether a tax cut of $¥ 35,000$, or roughly $\$ 300$, per household has the same effect as one large enough to affect durable goods or housing spending. The varying size of Japan's several recent stimulus packages offers an opportunity to examine this question, and Posen (1998) asserts that the larger spending and tax package of 1995 had a greater than proportionate impact compared with smaller packages. 
macroeconomics indicate that many of the lessons for policy developed here might be reversed in a small, open economy. In particular, it has long been held that full liberalization of capital flows would diminish the effectiveness of fiscal policy measures. Japan in this sense may have benefited from the fact that so little of its savings is internationally mobile, and so little of its debt is held by foreigners. Over time, even if the high end of potential growth estimates is confirmed, Japan will shrink in size relative to the rest of the world economy, and presumably it will eventually become more open. Is it the fate of all economies except the United States and the euro area (and perhaps eventually China) to have to give up the standard macroeconomic tools, or at least find their effectiveness more limited? This is a recurring theme in many of the more thoughtful criticisms of recent developments in emerging markets under capital account liberalization. On the other hand, had Japanese policymaking been subjected to greater discipline from capital inflows and outflows, perhaps it would never have fallen into the trap it did.

This brings us to the political economy question, or rather questions. The first is, To the extent that Japanese macroeconomic policies pursued in response to the Great Recession were less than optimal, why were those policies chosen? The breakdown of partially deregulated financial systems, and the incentives for regulatory forbearance, are well set out and understood. ${ }^{154}$ The major approach available today to understanding the choice of macroeconomic policies, however, is that of the institutional or "political economics" school, ${ }^{155}$ which has difficulty explaining two troublesome facts about Japan. One is that, looking cross-nationally, Japan has often been an outlier in terms of its macroeconomic policy behavior, given its institutional framework; the other is that Japanese policy choices have varied widely over the recent period with almost no variation in policymaking institutions. Older schools of political economy, such as those taking bureaucratic politics or partisan approaches, also have difficulty with the variation in policy in Japan, unless they make circular arguments with regard to the dependent variable. ("The Liberal Democratic Party is actually a coalition of parties, and should not be thought of as one party. Why? Because it behaves like a coalition.") One can offer an explanation based

154. See Mikitani and Posen (2000), Cargill, Hutchison, and Ito (2000), and Hoshi and Kashyap (2001).

155. Drazen (2000) and Persson and Tabellini (2000) summarize this literature. 
on the ideology and interests of those in control of the policy apparatus, but to do so requires a great deal of detailed documentation if it is to be anything more than a convenient labeling of a residual. ${ }^{156}$

The second political economy question is the much-contested issue of whether countercyclical policies in Japan in the 1990s-to the extent they were in fact pursued-interfered with, abetted, or had no effect upon the pace of resource reallocation and structural reform during the Great Recession. In short, did fiscal and monetary stimulus act as a narcotic, buying off demands for structural reform? There is little disagreement that allocative efficiency has not markedly improved in Japan in the last ten years, or that the structural reforms actually implemented were only a fraction of those proposed by the Japanese government, let alone by interested observers in the private and international official sectors. In analyzing the causes of this lack of reform, an evident difficulty is that one has only one case to study rather than a selection of cases to analyze in a comparative framework. With only one lengthy event to scrutinize, it is difficult to agree on the baseline: would there have been a greater or lesser rise in lending to retail relative to manufacturing firms, for example, under a looser monetary policy? True, the lower the interest rate, the easier it is for troubled firms to make their payments and avoid going out of business, but it is also true that the lower the interest rate, the more credit is available for new entrants. On the fiscal side, did the marked rise in construction employment in Japan in the last decade come as a result of efforts to fight the downturn with public works, or did the explosion of public works reflect the ability of an already protected construction sector to demand greater benefits when times grew hard? The existence and nature of a trade-off between stabilization policy and structural reform are an important topic for future exploration.

156. Posen and Kar (forthcoming) make an attempt at such an argument. 


\section{Comments and Discussion}

Stanley Fischer: ${ }^{1}$ This interesting paper by Kenneth Kuttner and Adam Posen presents persuasive evidence that the Japanese economy reacts in the textbook way to monetary and fiscal policy, and that the weakness of the Japanese financial system is a drag on economic performance and the effectiveness of policy. The message is "to trust what you learned in intermediate macroeconomics class"- a conclusion with which I am bound to agree.

Rather than focus on the details of the evidence, I want to take up the obvious question the paper raises: Why, if the answer is so simple, have policymakers allowed the Japanese economy to perform so poorly for almost a decade? One reason is that Japanese economic performance during the 1990s, although unimpressive, was not disastrous; policy would probably have been more decisive had Japan experienced a deep crisis rather than chronic underperformance. Kuttner and Posen are right to call this the Great Recession, rather than a great depression, for the economy grew, albeit very slowly and inconsistently, during the decade.

It is hard to know how far below potential the Japanese economy was operating at the end of the decade. The standard measures imply a gap of 3 to 4 percent of potential GDP, which is surprisingly small. By assuming that labor productivity grew during the 1990s at the previous decade's rate of 2.5 percent a year, the authors manage to raise the gap to 11 percent of potential GDP, which is more formidable, but less plausible. ${ }^{2}$ It is tempt-

1. The views expressed are those of the author and not necessarily of the International Monetary Fund.

2. This method makes it possible to generate huge gaps for any economy, even a fully employed economy, in which productivity growth has slowed. 
ing to conclude that the right measure is somewhere in between, but whatever the right measure, there is no doubt that the Japanese economy substantially underperformed during the last decade and shows no signs of strengthening at present.

Japanese policy during the 1990s becomes easier to understand by looking at growth year by year during the decade. Growth in 1990 was 5 percent, and in 1991 it was 4 percent-this being the end of the asset price bubble boom of the late 1980s. There was then a lengthy recession, lasting through 1995, during which growth averaged less than 1 percent a year. This could be explained, and was explained, as the price that had to be paid for the excesses of the previous decade. It is unlikely that Japanese policymakers were particularly concerned about long-run problems in the economy at the middle of the 1990s, although the strengthening of the yen exchange rate to 80 to the dollar in the spring of 1995 did give cause for concern and led to coordinated intervention that soon reversed the appreciation.

With growth at 3.6 percent in 1996, the recession seemed to be over, and the authorities decided it was time to clean up the budget. During the 1980s Japan had moved into budget surplus, and the 1996 deficit, which reached 4 percent of GDP, did not sit well with the Ministry of Finance, particularly with the aging of the population in prospect.

So it was decided to raise the value-added tax starting in July 1997; the total fiscal tightening was close to 2 percent of GDP. Predicting the impact of the tax change was complicated by the intertemporal substitution induced by the VAT increase, which caused spending to rise rapidly in the second quarter of 1997. Growth in that quarter was very high-and then the economy fell off the edge of the cliff. And all this just as the Asian crisis was beginning.

Why was the strong impact of the tax increase not foreseen? Partly because economists and policymakers were then paying a great deal of attention to the possibility of expansionary fiscal contractions-even though, as Kuttner and Posen remind us, the circumstances of the Japanese economy were not conducive to that outcome. Another factor was confidence that the growth momentum of 1996 was sufficiently strong to withstand a negative fiscal impulse, and another was that the strong intertemporal substitution caused by the VAT increase was not anticipated. Thus it was only in the second half of 1997 that it became clear that the economy might be suffering from a deep set of problems; in other words, 
only in the last third of the decade did policymakers begin to understand how serious were the problems confronting the Japanese economy.

Fiscal policy turned expansionary again in the second half of 1997. However, budgetary conventions in Japan complicate the task of setting a clear path for fiscal policy, because there is always uncertainty until late in the year, after the initial budget has been introduced, as to whether there will be a supplementary budget. There was a supplementary budget each year for most of the 1990s, but custom decrees that this issue not be discussed too early in the year.

Indeed, there is a general problem of fiscal transparency in Japan. Local governments report their budget data with a long lag, and this matters because they are responsible for the bulk of public works spending. According to a recently published IMF report, ${ }^{3}$ the key issues are lack of consolidation among different fiscal units and the absence of quarterly data, which means that fiscal information is on average about eight months out of date.

The lack of certainty about fiscal expansion dilutes its impact. Kuttner and Posen's results also imply that tax cuts would be more expansionary than expenditure increases of the same size. This is surprising on general principles, but believable in the Japanese case, particularly given the unpopularity of fiscal expansion through public works, which are often regarded as both useless and suspect in light of the political links between the government and contractors.

The general government deficit in Japan has been very large in recent years, reaching 8 percent of GDP in 2000. But the shift to large deficits started only in 1998. From 1995 to 1997 the deficit averaged 3.6 percent of GDP; from 1999 to 2001 it has averaged 7.2 percent of GDP. Excluding social security, the deficit in 2000 was 9.2 percent. The different measures of the deficit cause some confusion. So do the different measures of the government debt, which give very different pictures. Those who emphasize the dangers of fiscal expansion in Japan point to the total government debt, which was 140 percent of GDP in 2001. The net debt, or total debt minus government assets, was under 50 percent of GDP in 2001. The total debt excluding debt held by the social security system was 100 percent of GDP in 2001.

3. International Monetary Fund (2001). 
Although these levels differ greatly, their rates of change do not: all three increased at a rate of 7 to 10 percent of GDP a year over the period 1996-2001. So long as the real interest rate on the debt is around 1 to 2 percent, the interest burden is manageable. But those real rates cannot be guaranteed, particularly if the debt continues to increase. Thus, even if Japan does not have a fiscal problem now, it will have one if present trends continue. This means that Japan's fiscal policy is not sustainable for the long run, and thus that current levels of fiscal stimulus will have to be cut back at some point. Many Japanese policymakers feel that point is now. But given that at current interest rates the burden is not very large, the deficit should be reduced only very gradually, unless and until the economy becomes overheated and needs fiscal cooling.

Why was monetary policy not more expansionary earlier? An important factor that has certainly restrained the Bank of Japan's enthusiasm is the memory of the asset price bubble- the view that monetary policy was too expansionary in the late 1980s and early 1990s. The problem is that no central bank has yet worked out precisely how to deal with asset price inflation; Japan was not suffering from inflation during the period of high asset prices (including for land, which reached exorbitant values), and it is still not obvious that monetary policy should have been tightened during that period.

In any case, monetary policy has been very cautious. The Bank of Japan sometimes still warns about the risks of inflation, even though the GDP deflator has been declining since 1994, and the CPI has not risen at an annual rate of more than 1 percent in any year since 1994 and has been declining for the last few years. Another argument for monetary caution that does not seem to bear much weight is the concern that very low interest rates provide the wrong incentives for structural reform-that they encourage waiting for better times rather than getting on with the tough tasks of restructuring.

Policy interest rates were cut to close to zero in 1996 and have been in that range since. What else should Bank of Japan policymakers have done? They have been urged to buy foreign exchange, and they have done that: foreign exchange reserves have risen by about 3 percent of GDP, or 50 percent of the monetary base, in the last three years. But those purchases have been sterilized. Those who recommend unsterilized intervention say the government should not sell bonds when it buys foreign exchange; in other words, it should be buying more bonds, on net, than it has been recently- 
and the monetary base should be expanding more rapidly than it has. The monetary base in Japan expanded on average by 6.5 percent a year during the second half of the 1990s, albeit with considerable fluctuations; thus the money base has been rising in real terms by over 7 percent a year.

Kuttner and Posen urge the Bank of Japan to be more aggressive in open market operations. It could do this by moving up the term structure and buying long-term bonds. It has resisted doing so, however, probably for fear that it could end up being forced to guarantee the prices of government bonds.

I agree with the authors' recommendation, but we should not exaggerate its likely effect, for consider how such a strategy would work. The Pigou solution to the liquidity trap relied on wealth effects to get the economy out of a recession. But the wealth effect of even massive purchases of assets by the Bank of Japan would be small. More likely, unsterilized foreign exchange and other open market purchases would work mainly through two other routes: by causing further reductions in long-term interest rates, and through depreciation of the yen. The interest rate effect would probably be small, and the yen depreciation effect would be a beggar-thy-neighbor policy and could not be pushed too far. Thus more intensive open market purchases would probably not have a decisive impact on the economy.

Inflation targeting provides a framework in which a more expansionary monetary policy could be carried out. Massive asset purchases might begin to generate expectations of inflation, including to some extent through yen depreciation (although the exchange rate pass-through to inflation seems to be small in Japan). Even though it is highly uncertain that monetary policy currently has sufficient leverage to ensure the credibility of an inflation targeting approach, the advice to try monetary expansion should be followed.

The authors' evidence that the state of the financial sector matters for the transmission of monetary policy is important. Why has progress on bank and corporate restructuring been so slow? The first answer is that bankers are extremely unpopular, and there is little support for providing public money to help the banks (this is not a uniquely Japanese phenomenon). The authorities could not move on the banks until actual bank runs occurred in November 1997, at which point the public realized that something needed to be done. Since then the authorities have been behind the curve, slow to recognize the extent of nonperforming loans. Private 
analysts' estimates have generally exceeded the official estimates and have generally turned out to be more accurate. This phenomenon has been difficult for the responsible officials - and they are responsible, and many of them are very able - to accept, and it has led to some friction on occasion with the IMF. It would be an injustice to the Financial Services Agency not to recognize that progress has been made in dealing with the banking system. Unfortunately, however, at no time has the official sector really gotten on top of the problem.

Japanese policymakers today face an exceptionally difficult and unenviable situation. Fiscal policy can continue to be expansionary, but there is little room for an additional fiscal impulse. Monetary policy can be made more expansionary, but the country is in a liquidity trap, and not much expansion can be expected from monetary policy unless the yen depreciates significantly - and that will create problems for other countries. The banks need to be restructured, as does the corporate sector, but that would be contractionary in the short run. No wonder that under these circumstances the Japanese authorities have been slow to grasp the nettle. But until they do, the economy's slow growth and prolonged recession are likely to continue.

John Makin: One can discuss this paper either by critiquing the econometrics or by discussing the policy conclusions. I will focus on the policy side of the paper, and I will talk a little about the macroeconomic lessons, for the United States as well as for Japan.

This is an ambitious paper, but I think it makes a valuable contribution to the policy debate on ways to end Japan's decade-long recession. It subjects to econometric analysis the seemingly obvious propositions that monetary and fiscal policies work in Japan just as standard macroeconomic analysis suggests, and that the insolvency of Japan's banking system has played a significant role in perpetuating this Great Recession.

The authors summarize their paper aptly by concluding that at times it is more important to test the stability of the ground on which one is standing than to break new ground. That said, to me the big mystery about Japan's Great Recession has not been why it has occurred, given the policy errors committed. Rather the mystery surrounds why Japan's policymakers, with ill-timed tax increases, persistently deflationary monetary policy, and a long-standing failure to address the growing insolvency in 
its banking system, have persisted in contributing to its continuation and even its intensification.

Maybe Japan's policymakers are waiting for the Pigou effect to come into play. If prices fall far enough, perhaps wealth will increase enough so that expenditure will increase. This, of course, is a scary experiment, rather like a bungee jump. The Japanese price level can go down a long way before it bounces back. I would argue that policy mistakes in Japan have been so large and obvious that Kuttner and Posen's worthy effort is like that of a doctor who, having observed a patient with no brain function or heartbeat for an hour, pronounces the patient dead.

Kuttner and Posen adduce evidence for the following not-so-radical ideas: that persistent increases in M2 cause the price level to rise; that when those increases are faster than they are in the United States (the case they look at), they can cause the yen to depreciate against the dollar; that tax cuts and increases in government spending produce an increase in GDP, with tax cuts having somewhat more of an effect; and that Japan's insolvent banking system has contributed to the intensity of the Great Recession.

The authors might want to refer specifically to the program initiated in 1998 , when the Japanese government devoted between $¥ 20$ trillion and $¥ 30$ trillion in loans to small and medium-size firms that no one else would lend to. Beyond the more obvious policy errors, the Japanese government was in this case pushing money in the wrong direction and slowing the structural change that is necessary in Japan.

The authors' presentation is accomplished within the context of a valuable review of the literature that makes a worthwhile addition to the length of the paper. In my view, the most dangerous notions to emerge from that literature and from the broader debate over Japan's Great Recession, on the monetary side, include Bank of Japan Governor Hayami's idea of a "good" deflation. On the fiscal side, the notion of expansionary fiscal contraction, which led to the massive tax increase in the spring of 1997 and drove Japan into another recession, is the most dangerous.

Kuttner and Posen appropriately treat the idea of good deflation as one that must be considered carefully, distinguishing changes in relative prices from changes in the overall price level. Technological change, of course, leads to a drop in the relative price of a given product or set of products, such as communications equipment, and is a good thing. 
However, monetary policy that is too tight leads to aggregate deflation, which can persist over a period of time—-seven years in Japan's case—and it has been dangerously contractionary. But good deflation on an aggregate level suggests an outward shift in the aggregate supply schedule, and therefore suggests that falling prices should coincide with rising output. In Japan, falling prices have more often coincided with falling output, suggesting that the deflation is the result of persistently shrinking aggregate demand.

In discussing monetary policy, Kuttner and Posen are perhaps a little bit too detached. They say that much debate is centered on whether the Bank of Japan acted appropriately in the light of macroeconomic circumstances, and that they do not intend to rekindle this debate. But they will indeed rekindle the debate, and appropriately so. Of course, they do suggest—and I suppose this is meant to be the respectful way to criticize the Bank of Japan - that their impulse response functions indicate that Japan's monetary policy was slow to respond to deflationary developments in the 1990s. I would say, slow indeed.

On the fiscal side, Kuttner and Posen debunk the notion of expansionary fiscal contraction that apparently served as the rationale for Japan's tax increase in 1997. The mechanism by which fiscal contraction somehow increases demand growth is the removal of the fear of unstable debt dynamics that leads to lower interest rates and more consumption. Indeed, this is a critical point in policy discussions today, both in the United States and in emerging markets like Argentina. What I term the Rubin fallacythat paying down the national debt is somehow responsible for the American boom of the late 1990s - has led some to conclude that taxes should not be cut even when the U.S. economy is slowing sharply.

As Kuttner and Posen point out, careful empirical analysis of the impact of tax cuts on economic activity must allow for the causality running from GDP to tax revenue: "as GDP falls, tax revenue shrinks." But to conclude from this that tax cuts are contractionary is incorrect. (Congress, take note.) On the other hand, as GDP rises, thanks to an investment boom like the one we saw in the United States in the 1990s, tax revenue rises and the deficit shrinks. However, the causality runs from the stronger economy to the lower deficit, not the other way around.

Perhaps more macroeconomic lessons from Japan's Great Recession can be gleaned from looking carefully at its nature. Here I am proposing what may be some useful additions to the diagnostic section of the paper 
that may enrich the structure of the data, which the authors can use to identify more parameters in testing the effects of monitoring fiscal policy.

Japan's Great Recession was, of course, preceded by a dramatic collapse of its stock market, which fell by over 60 percent between the start of 1990 and the end of 1991. Stock market losses and lower land prices eventually accumulated to a wealth loss in Japan of $¥ 15$ trillion, which is about three years' income. That is substantial and should, perhaps, suggest some empirical evidence with respect to the wealth effect, because a shortage of demand has been a critical and chronic problem in Japan, as evidenced by its accelerating deflation.

Japan's Great Recession was preceded by a period of what turned out to be overinvestment, which generated excess capacity and fed into a land price bubble. The overinvestment-based expansion, followed by an equity market collapse tied, in turn, to problems of excess capacity, is perhaps a relevant example for American policymakers to consider today.

The Great Recession itself really has had two major phases. And, as I mentioned, exploiting its details might enhance the ability to do empirical work on the effects of monitoring fiscal policy in Japan. Year over year, real investment in Japan fell sharply, subtracting 1 to 2 percentage points from annual GDP growth from the fourth quarter of 1991 through the first quarter of 1994. During this period, positive contributors to Japanese growth were private consumption and so-called government investment, although the distinction between government investment and government consumption in Japan is another issue. Some of the things that are called investment may not be. In short, through 1995 Japan experienced a massive and persistent collapse of investment spending, which was offset by sustained consumption growth and sustained public spending programs.

Net exports also contributed positively to growth during 1991 and 1992 and into the start of 1993, but then their contribution turned negative. And here, of course, we get into an area of controversy with respect to how Japan might get itself out of recession.

The pattern whereby a stock market bubble is followed by a sharp contraction in private investment and persistent growth of private consumption, partly cushioned by central bank easing, may, as noted already, be of interest today to American policymakers. The investment slowdown following the collapse of the stock market bubble can persist over three years, even as the central bank's efforts to stimulate aggregate demand cushion the impact on consumption. 
In early 1995 Japan's government investment spending and net exports fell rapidly. A crisis of sorts emerged in the spring of 1995. And this, I think, was a very interesting episode that might be worth looking at more closely.

Japan's stock market fell sharply while the yen appreciated rapidly. The Bank of Japan ignored this pair of developments, whose simultaneity can only be explained by the emergence of a deflationary liquidity trap that reduces capital outflows, while simultaneously investors pull funds out of the equity market. Once the yen had spiked to 80 to the dollar, the Bank of Japan belatedly responded by pushing down interest rates and organizing a huge increase in government spending.

As I wrote in December 1996, "Suppose that, during the year running from the summer of 1995 through the summer of 1996, American policy makers had increased federal spending by $\$ 250$ billion (3 percent of the gross domestic product), cut short-term interest rates to below one half of 1 percent, and flooded the economy with liquidity so that long-term interest rates were held below 3 percent while the dollar weakened by 30 percent, making our goods far cheaper in world markets. U.S. growth and employment would have boomed, and inflation would have jumped as the economy overheated." ${ }^{1}$ Yet these are precisely the steps that Japanese policymakers took after the summer of 1995, and they had little lasting positive impact on the Japanese economy. The payoff was a brief surge of growth to an annualized rate of 12.2 percent during the first quarter of 1996.

Meanwhile Japan's stock market also rose. The massive stimulus did create a strong recovery going into 1997, and as the authors' figure 1 shows, there was actually a brief move above potential growth during that period.

Then, in the first quarter of 1997, apparently enchanted with the notion of expansionary fiscal contraction, the Japanese government elected simultaneously to increase payroll taxes and increase consumption taxes from 3 to 5 percent. Most observers emphasize the rise in the consumption tax rate. But I think the increase in payroll taxes, and the increase in copayments on medical insurance for a largely elderly population, were very damaging to people's expectations of future disposable income.

1. John H. Makin, “Japan's Disastrous Keynesian Experiment,” AEI Economic Outlook, December 1996 (Washington: American Enterprise Institute), p. 1. 
This disastrous flirtation with fiscal orthodoxy right out of America's Great Depression collapsed demand growth and threw Japan back into recession. The fiscal drag, equivalent to at least 2 percent of GDP, was accompanied by a resumption of negative investment growth and a sharp weakening of private consumption during 1997 and early in 1998.

The Japanese economy, in the wake of its sharp reduction of domestic absorption, relied for growth upon a surge in net exports. In the presence of deflation, the impact of Japan's lurch toward contractionary fiscal policy probably contributed heavily to the emergence of the East Asian crisis in 1997 and 1998. And that in turn further reduced the ability of Japan's banks to continue lending. The effect of the emerging Asian crisis on what was going on in Japan might be something to look at in the context of an open-economy model.

Japan, of course, responded to the collapse of its economy in 1997 and 1998 with a resumption of massive fiscal stimulus beginning in the summer of 1998. About $¥ 40$ trillion worth of nominal stimulus was added in the second half of the year, equivalent to nearly 10 percent of Japanese GDP. That would be equivalent to a U.S. stimulus package of about $\$ 1$ trillion. No doubt that would be labeled "contractionary" by critics of the moderate fiscal stimulus being effected now by the U.S. government.

At the time, few noticed that although the Japanese economy was starting to grow again, private investment remained a drag on overall growth. The deflationary environment fostered by the Bank of Japan's failure to look at real interest rates, coupled with anxiety over the Asian crisis, was probably partly to blame. Beyond that, much of Japan's fiscal stimulus went to wasteful public spending. Those of you who have been to Japan recently have probably noticed the new tunnel under Tokyo Bay, which reminds me of the old graduate school example of filling in the Gulf of Mexico.

Kuttner and Posen ably document other problems plaguing the Japanese economy, including its nonfunctioning banking system. As already noted, it is very difficult for private investment to thrive when government policies are largely designed to allocate funds away from strong sectors of the economy and toward weak sectors.

The Japanese "recovery" in 1998 and in 1999, driven by the huge fiscal stimulus of the second half of 1998, faltered at the end of 1999 with the collapse of private consumption. Many were misled by the 10 percent annualized growth recorded during the first quarter of 2000. Clearly there 
is a problem with the seasonal adjustment of the Japanese data, because first quarters often display double-digit growth. That did not happen this year, but relative to growth in the second quarter, that in the first was still rather strong.

Overlooking the fact that much of the increase in real growth was actually associated with weak nominal growth, as underscored by the authors' note on GDP statistics in 2001:2, the Bank of Japan elected to abandon its zero interest rate policy in August 2000. Although the increase in interest rates of only 25 basis points appeared modest, the bank was sending a harmful signal that rates would continue to rise in the context of a recovering economy. The move also signaled the central bank's expectation of a reversal of the deflationary trend in Japan, and this pushed up longerterm interest rates. Unfortunately, this ill-timed move coincided with the onset of global slowdown and an intensification of deflationary pressures in Japan.

In the context of the history of deflation and recession in Japan over the past year, the speech by Governor Hayami on March 21, 2000, from which the authors quote, speaks for itself. Clearly, Hayami still saw inflation risks where the real risk lay with accelerating deflation. There is an ongoing problem with Japan's official data on inflation and deflation-the Bank of Japan is constantly reworking the data and revising down, as they did again recently, the actual measure of inflation. But sadly, in retrospect, Governor Hayami's speech makes it clear that a necessary condition for an end to Japan's disastrous deflation is Governor's Hayami's retirement.

Moving forward, the outlook for Japan's economy is still problematic insofar as policymakers there display no evidence of having learned the lessons embedded in Kuttner and Posen's paper. The new government of Junichiro Koizumi is hesitating to deal with the nonperforming loans problem. The Liberal Democratic Party-controlled Diet is ginning up another supplementary budget, which may contain modest fiscal stimulus on the order of about half a percent of GDP, but also will contain some wasteful spending, as most LDP-sponsored packages do.

The Bank of Japan, meanwhile, is continuing its half-hearted efforts to revive the economy by making loans available to a moribund banking system at zero interest, ignoring the need to bypass the banking system and directly purchase either government bonds or foreign exchange. Clearly, the Bank of Japan, through a perverse announcement effect, is harming 
Japan's economy by preannouncing the ineffectiveness of expansionary monetary policy, and then providing liquidity to a banking system that has ceased to function.

If the Bank of Japan were to purchase government bonds, or directly purchase foreign exchange without sterilizing it, surely inflation would rise, if by no other means than a weaker yen. But thanks to Kuttner and Posen, at least Japan's policymakers cannot claim that they have done everything possible to address the serious problems that confront the Japanese economy, or that the policy tools available to them have not worked. We can only hope that Kuttner and Posen will succeed where others have failed, and that their paper will convince the Bank of Japan to move aggressively to directly purchase foreign exchange or government bonds. These are necessary, but not sufficient, conditions for a sustained recovery of growth in Japan. But surely it is time for Japan to begin to take these steps, and for other policymakers in the Group of Seven countries to protest their failure to do so.

General discussion: Several panelists discussed the likely importance of structural effects in Japan's long recession. Edmund Phelps argued that the authors were overlooking the importance of nonmonetary mechanisms in the slump. He noted that a fall in the valuations that entrepreneurs place on each of their business assets - customers, machines, management knowhow-causes investment in those assets to drop, which may in turn cause a structural shift in the equilibrium level of unemployment. In addition, a drop in consumption demand in an open economy might cause a real depreciation of the currency that engenders a structural contraction, which would be the reverse of the Keynesian effect. A depreciation, like tariff protection, invites firms to raise their markups, thus cutting output supply and labor demand. Phelps did not rule out that a Keynesian deficiency of aggregate demand might cause employment to slip below its already worsened nonmonetary equilibrium path, but he emphasized the importance of the structural component in Japan's case. He also reasoned that nonmonetary intertemporal models could incorporate some of the factors on which the authors focused. These would include weakening investment spending through the loss of information capital that results from stress to the financial system. Michael Burda added that structural effects in the labor market seemed important. Given Japan's bonus system of compensation, the sharply lower profitability of firms had caused real wages to 
become depressed. He noted the finding of some analysts that the labor supply curve had shifted inward, which could be an outcome of institutional changes.

Martin Baily also saw the supply side of the economy as an important part of Japan's problem. Productivity in Japan, as measured by GDP per hour worked, is only about two-thirds that in the United States, despite an equal or greater capital intensity in Japan. This clearly suggests something wrong on the supply side. A correspondingly low return to capital contributes to inadequate demand by inhibiting investment spending. Baily reasoned that institutional arrangements in labor and product markets and in banking needed to be changed to allow unprofitable companies to fail and to encourage profitable new investments to be made. Eliminating the maze of government regulations that now impedes investment would be one useful step. But he also acknowledged that current economic modeling, with its stress on the demand side, has not come to grips with why Japan, along with other Pacific Rim economies, worked so well for so long and now faces problems that are so poorly understood.

Joseph Stiglitz agreed that supply-side problems may be important, particularly in open economies. But he also attached importance to demand effects and discussed some shortcomings in the typical analysis of the demand side and in policy recommendations for dealing with it. He observed that wages and prices in Japan are reasonably flexible, so that the traditional Keynesian emphasis on price rigidities as a source of friction and unemployment is unwarranted. He also discussed the effects of taxes and dynamic consistency. Using the logic of Ricardian equivalence, he reasoned that the large government deficits in Japan should have reduced the effectiveness of long-term tax cuts as a fiscal stimulus. He suggested that a more dynamically consistent policy that could stimulate current consumption would be a temporary cut in the value-added tax combined with the promise of a future increase, which would be credible because of the large deficits. As to the effects of Japan's past high deficits, Stiglitz posed the counterfactual: would output and aggregate demand have been higher in their absence?

Addressing the issue of the liquidity trap, Stiglitz conceded that providing a malfunctioning banking system with liquidity does not necessarily increase aggregate demand. But that does not imply that the optimal policy response would have been to shut down more banks. If more banks had been closed, as many have advocated, the loss in information capital 
would have been serious, and the credit crunch could have been worsened. With respect to future policy, he cautioned that restructuring in a time of global recession risked exacerbating the downturn.

William Dickens questioned whether the off-the-shelf techniques used in the paper were applicable to Japan in the 1990s. He suggested a more extensive discussion of why relationships from earlier decades would be expected to hold in the 1990s, along with tests of the structural stability of those relationships. Robert Hall observed that the idea of potential output is particularly questionable for Japan. He felt that, without a firm basis for saying where the Japanese economy ought to be, it is hard to diagnose the sources of its poor performance. 


\section{References}

Alesina, Alberto, and Lawrence H. Summers. 1993. "Central Bank Independence and Macroeconomic Performance: Some Comparative Evidence." Journal of Money, Credit, and Banking 25(2): 151-62.

Ando, Albert. 2000. "On the Japanese Economy and Japanese National Accounts." Working Paper 8033. Cambridge, Mass.: National Bureau of Economic Research (December).

Aoki, Masahiko, and Hugh T. Patrick, eds. 1994. The Japanese Main Bank System: Its Relevance for Developing and Transforming Economies. Oxford University Press.

Asako, Kazumi, Takatoshi Ito, and Kazunori Sakamoto. 1991. "The Rise and Fall of Deficit in Japan, 1965-1990." Journal of the Japanese and International Economy 5(4): 451-72.

Asher, David L. 2000. “Japan's Financial Mt. Fuji: Threatening Economic Stability.” Unpublished paper. Washington: American Enterprise Institute (December).

Asher, David L., and Robert H. Dugger. 2000. “Could Japan's Financial Mount Fuji Blow Its Top?” MIT-Japan Program Working Paper 00-01. Massachusetts Institute of Technology (web.mit.edu/mit-japan/Products/wp00-01.html, accessed on August 20, 2001).

Asher, David L., and Andrew Smithers. 1998. "Japan's Key Challenges for the 21st Century: Debt, Deflation, Default, Demography and Deregulation." SAIS Policy Forum Series. Washington: Paul H. Nitze School of Advanced International Studies of The Johns Hopkins University (March).

Balassa, Bela, and Marcus Noland. 1988. Japan in the World Economy. Washington: Institute for International Economics.

Ball, Laurence, and N. Gregory Mankiw. 1995. "What Do Budget Deficits Do?" Budget Deficits and Debt: Issues and Options. A Symposium Sponsored by the Federal Reserve Bank of Kansas City. Kansas City, Mo.: Federal Reserve Bank of Kansas City.

Bayoumi, Tamim. 1998. "The Japanese Fiscal System and Fiscal Transparency." In Structural Change in Japan: Macroeconomic Impact and Policy Challenges, edited by Bijan B. Aghevli, Tamim Bayoumi, and Guy Meredith. Washington: International Monetary Fund.

- 2001. "The Morning After: Explaining the Slowdown in Japanese Growth in the 1990s." Journal of International Economics 53(2): 241-59.

Berg, Claes, and Lars Jonung. 1998. "Pioneering Price Level Targeting: The Swedish Experience 1931-1937." Working Paper Series in Economics and Finance 290. Stockholm: Stockholm School of Economics.

Bergman, U. Michael, and Michael M. Hutchison. 1999. "Economic Expansions and Fiscal Contractions: International Evidence and the 1982 Danish Stabi- 
lization." In Macroeconomic Perspectives on the Danish Economy, edited by Torben M. Andersen, Svend E. Jensen, and Ole Risager. Macmillan Press.

Bergsten, C. Fred, Takatoshi Ito, and Marcus Noland. 2001. No More Bashing: Building a New Japan-United States Economic Relationship. Washington: Institute for International Economics.

Bernanke, Ben S. 1983. "Nonmonetary Effects of the Financial Crisis in Propagation of the Great Depression." American Economic Review 73(3): 257-76.

—. 1995. "The Macroeconomics of the Great Depression: A Comparative Approach.” Journal of Money, Credit, and Banking 27(1): 1-28.

- 2000. "Japanese Monetary Policy: A Case of Self-Induced Paralysis?" In Japan's Financial Crisis and Its Parallels to U.S. Experience, edited by Ryoichi Mikitani and Adam S. Posen. Washington: Institute for International Economics.

Bernanke, Ben S., and Mark Gertler. 1990. "Financial Fragility and Economic Performance." Quarterly Journal of Economics 105(1): 87-114.

2000. "Monetary Policy and Asset Price Volatility." Working Paper 7559. Cambridge, Mass.: National Bureau of Economic Research (February).

Bernanke, Ben S., and Cara S. Lown. 1991. "The Credit Crunch.” BPEA, 2:1991, 205-39.

Bernanke, Ben S., and others. 1999. Inflation Targeting: Lessons from the International Experience. Princeton University Press.

Blanchard, Olivier. 2000. "Bubbles, Liquidity Traps, and Monetary Policy." In Japan's Financial Crisis and Its Parallels to U.S. Experience, edited by Ryoichi Mikitani and Adam S. Posen. Washington: Institute for International Economics.

Blanchard, Olivier, and Michael Kremer. 1997. "Disorganization.” Quarterly Journal of Economics 112(4): 1091-1126.

Blanchard, Olivier, and Roberto Perotti. 1999. “An Empirical Characterization of the Dynamic Effects of Changes in Government Spending and Taxes on Output." Working Paper 7269. Cambridge, Mass.: National Bureau of Economic Research (July).

Bosworth, Barry P. 1993. Saving and Investment in a Global Economy. Brookings.

Buiter, Willem H., and Kenneth M. Kletzer. 1992. "Who's Afraid of the Public Debt?" American Economic Association Papers and Proceedings 82(2): 290-94.

Cargill, Thomas F. 1993. "The Bank of Japan: A Dependent but Price Stabilizing Central Bank." Public Budgeting and Financial Management 5: 131-39.

Cargill, Thomas F., Michael M. Hutchison, and Takatoshi Ito. 1997. The Political Economy of Japanese Monetary Policy. MIT Press.

- 2000. Financial Policy and Central Banking in Japan. MIT Press.

Carlile, Lonny E., and Mark C. Tilton, eds. 1998. Is Japan Really Changing Its Ways? Regulatory Reform and the Japanese Economy. Brookings. 
Carroll, Christopher D. 2000. " 'Risky Habits' and the Marginal Propensity to Consume out of Permanent Income, or, How Much Would a Permanent Tax Cut Boost Japanese Consumption?” Working Paper 7839. Cambridge, Mass.: National Bureau of Economic Research (August).

Chirinko, Robert S., and Huntley Schaller. 2001. "Business Fixed Investment and 'Bubbles': The Japanese Case.' American Economic Review 91(3): 663-80.

Cukierman, Alex. 1992. Central Bank Strategy, Credibility, and Independence: Theory and Evidence. MIT Press.

Cukierman, Alex, and Allan H. Meltzer. 1986. "A Theory of Ambiguity, Credibility and Inflation under Discretion and Asymmetric Information." Econometrica 54 (5): 1099-1128.

Debelle, Guy, and Stanley Fischer. 1994. "How Independent Should a Central Bank Be?" In Goals, Guidelines, and Constraints Facing Monetary Policymakers, edited by Jeffrey C. Fuhrer. Federal Reserve Bank of Boston.

Demiralp, Selva, and Oscar Jordá. Forthcoming. "The Announcement Effect: Evidence from Open Market Desk Data.” Federal Reserve Bank of New York Economic Policy Review.

Dominguez, Kathryn M., and Jeffrey A. Frankel. 1993. "Does Foreign Exchange Intervention Matter? The Portfolio Effect." American Economic Review 83(5): 1356-69.

Drazen, Allan. 2000. Political Economy in Macroeconomics. Princeton University Press.

Eichenbaum, Martin, and Charles L. Evans. 1995. "Some Empirical Evidence on the Effects of Shocks to Monetary Policy on Exchange Rates." Quarterly Journal of Economics 110(4): 975-1009.

Eichengreen, Barry. 1992. Golden Fetters: The Gold Standard and the Great Depression, 1919-1939. Oxford University Press.

Faruqee, Hamid, and Martin Mühleisen. 2001. "Population Aging in Japan: Demographic Shock and Fiscal Sustainability.” IMF Working Paper 01/40. Washington: International Monetary Fund (April).

Fischer, Stanley. 1998. "The Asian Crisis, the IMF, and the Japanese Economy." Speech presented at the Asahi Shimbun Symposium, Tokyo, April 8. (www.imf.org/external/np/speeches/1998/040898.HTM, last accessed on December 7, 2001).

___ 2000. Comment on "The End of Stabilization Policy?" In Economic Events, Ideas, and Policies: The 1960s and After, edited by George L. Perry and James Tobin. Brookings.

Fisher, Irving. 1933. "The Debt-Deflation Theory of Great Depressions." Econometrica 1(4): 337-57.

Frankel, Jeffrey. 1984. "Tests of Monetary and Portfolio Balance Models of Exchange Rate Determination.” In Exchange Rate Theory and Practice, edited by John F. O. Bilson and Richard C. Marston. University of Chicago Press. 
Friedman, Benjamin M., and Kenneth N. Kuttner. 1992. "Money, Income, Prices and Interest Rates." American Economic Review 82(3): 472-92.

Friedman, Milton, and Anna Schwartz. 1963. A Monetary History of the United States, 1867-1960. Princeton University Press.

Fujiwara, Sakuya. 1999. "On Recent Economic and Financial Developments and Monetary Policy.” Speech presented to the Yomiuri International Economic Society, Tokyo, December 7 (www.boj.or.jp/en/press/koen046.htm, accessed on August 25, 2001).

Fukao, Mitsuhiro. 1995. Financial Integration, Corporate Governance, and the Performance of Multinational Companies. Brookings.

___ 2001. "Financial Deregulations, Weakness of Market Discipline, and Market Development: Japan's Experience and Lessons for Latin America and the Caribbean.” Unpublished paper. Tokyo: Keio University.

Genda, Yuji, and Marcus E. Rebick. 2000. "Japanese Labour in the 1990s: Stability and Stagnation." Oxford Review of Economic Policy 16(2): 85-102.

Gertler, Mark, and Simon Gilchrist. 1994. "Monetary Policy, Business Cycles, and the Behavior of Small Manufacturing Firms." Quarterly Journal of Economics 109(2): 309-40.

Giavazzi, Francesco, and Marco Pagano. 1990. "Can Severe Fiscal Contractions Be Expansionary? Tales of Two Small European Countries.” Working Paper 3372. Cambridge, Mass.: National Bureau of Economic Research (May).

Gibson, Michael S. 1997. "More Evidence on the Link between Bank Health and Investment in Japan." Journal of the Japanese and International Economy 11(3): 296-310.

Giorno, Claude, and others. 1995a. "Estimating Potential Output, Output Gaps, and Structural Budget Balances.” Working Paper 152. Paris: Organization for Economic Cooperation and Development.

. 1995b. "Potential Output, Output Gaps, and Structural Budget Balance." In OECD Economic Studies No. 24. Paris: Organization for Economic Cooperation and Development.

Goyal, Vidhan K., and Takeshi Yamada. 2000. "Asset Price Bubbles, Investment, and Liquidity: Evidence from Japan.” Unpublished paper. Department of Finance, Hong Kong University of Science and Technology (August).

Guthrie, Graeme, and Julian Wright. 2000. "Open Mouth Operations.” Journal of Monetary Economics 46(2): 489-516.

Hamilton, James D. 1994. Time Series Analysis. Princeton University Press.

Hayami, Masaru. 1999. “On Recent Monetary Policy.” Speech presented to the Japan National Press Club, Tokyo, June 22 (www.boj.or.jp/en/press/ koen038.htm, accessed on August 25, 2001).

__ 2000. "Price Stability and Monetary Policy." Speech presented to the Research Institute of Japan, Tokyo, March 21 (www.boj.or.jp/en/press/ koen050.htm, accessed on August 25, 2001). 
. 2001. "Recent Economic Developments and Monetary Policy." Speech presented to the Research Institute of Japan, March 7 (www.boj.or.jp/en/ press/koen066.htm, accessed on August 25, 2001).

Horioka, Charles Yuji. 1990. "Why Is Japan's Household Saving Rate So High? A Literature Survey." Journal of the Japanese and International Economy 4(1): 49-92.

1991. "The Determinants of Japan's Saving Rate: The Impact of the Age Structure of the Population and Other Factors." Economic Studies Quarterly 42(3): 237-53.

1993. "Saving in Japan." In World Savings: An International Survey, edited by Arnold Heetje. Oxford, England: Blackwell.

__ 1995. "Is Japan's Household Saving Rate Really High?" Review of Income and Wealth 41(4): 373-97.

. 1997. "A Conintegration Analysis of the Impact of the Age Structure of the Population on the Household Saving Rate in Japan." Review of Economics and Statistics 79(3): 511-16.

Horioka, Charles Yuji, and Wako Watanabe. 1997. "Why Do People Save? A Micro-Analysis of Motives for Household Saving in Japan." Economic Journal 107(442): 537-52.

Horioka, Charles Yuji, and others. 1996. "Do the Aged Dissave in Japan? Evidence from Micro Data." Journal of the Japanese and International Economies 10(3): 295-311.

Hoshi, Takeo, and Anil Kashyap. 1999. "The Japanese Bank Crisis: Where Did It Come from and How Will It End?" In NBER Macroeconomics Annual, edited by Ben S. Bernanke and Julio Rotemberg. MIT Press.

2001. Corporate Financing and Governance in Japan: The Road to the Future. MIT Press.

Hubbard, R. Glenn, Kenneth N. Kuttner, and Darius N. Palia. Forthcoming. "Are There Bank Effects in Borrowers' Costs of Funds? Evidence from a Matched Sample of Borrowers and Banks." Journal of Business.

Hutchison, Michael M. 1992. "Budget Policy and the Decline of National Saving Revisited.” BIS Economic Papers 33. Basle: Bank for International Settlements (March).

International Monetary Fund. 2000. Japan: Selected Issues. IMF Staff Country Report 00/144. Washington: International Monetary Fund (November).

- 2001. Japan: Report on the Observance of Standards and CodesFiscal Transparency Module. Country Report 01/156. Washington (September).

Ishi, Hiromitsu. 2000. Making Fiscal Policy in Japan: Economic Effects and Institutional Settings. Oxford University Press.

Ishii, Hiroko, and Erika Wada. 1998. "Local Government Spending: Solving the Mystery of Japanese Fiscal Packages." Working Paper 98-5. Washington: Institute for International Economics (July). 
Jerram, Richard. 2000. "The Construction of GDP Statistics in Japan." Paper presented at the NBER Japan Project Meeting, Tokyo, September 22-23.

Jinushi, Toshiki, Yoshihiro Kuroki, and Ryuzo Miyao. 2000. "Monetary Policy in Japan Since the Late 1980s: Delayed Policy Actions and Some Explanations." In Japan's Financial Crisis and Its Parallels to U.S. Experience, edited by Ryoichi Mikitani and Adam S. Posen. Washington: Institute for International Economics.

Kanaya, Akihiro, and David Woo. 2000. "The Japanese Banking Crisis of the 1990s: Sources and Lessons.” Working Paper 00/7. Washington: International Monetary Fund (January).

Kang, Jun-Koo, and René M. Stulz. 2000. "Do Banking Shocks Affect Borrowing Firm Performance? An Analysis of the Japanese Experience." Journal of Business 73(1): 1-23.

Kashyap, Anil K., and Jeremy C. Stein. 1995. "The Impact of Monetary Policy on Bank Balance Sheets." Carnegie-Rochester Conference Series on Public Policy 42: 151-95.

2000. "What Do a Million Observations on Banks Say about the Transmission of Monetary Policy?" American Economic Review 90(3): 407-28.

Katz, Richard. 1998. Japan, the System That Soured: The Rise and Fall of the Japanese Economic Miracle. New York: M. E. Sharpe Press.

Katz, Richard, and others. 2000. "Additional View: Managing the Trade-off between Macroeconomic Stimulus and Structural Reform." In Future Directions for U.S. Economic Policy Toward Japan, Report of an Independent Task Force sponsored by the Council on Foreign Relations. New York: Council on Foreign Relations.

Kiyotaki, Nobuhiro, and John Moore. 1997. "Credit Cycles." Journal of Political Economy 105(2): 211-48.

Kiyotaki, Nobuhiro, and Kenneth West. 1996. "Business Fixed Investment and the Recent Business Cycle in Japan.” In NBER Macroeconomics Annual, edited by Ben S. Bernanke and Julio J. Rotemberg. MIT Press.

Kobayashi, Keiichiro, and Masaru Inaba. 2001. "Disorganization Due to Forbearance of Debt Restructuring." Unpublished paper. Tokyo: Research Institute of Economy, Trade, and Industry (www.rieti.go.jp/fellow/kobayashikeiichiro/m4235-2.pdf, accessed on August 25, 2001).

Kotlikoff, Laurence J., and Willi Leibfritz. 1998. "An International Comparison of Generational Accounts." Working Paper 6447. Cambridge, Mass.: National Bureau of Economic Research (March).

Krugman, Paul R. 1998. "It's Baaack: Japan's Slump and the Return of the Liquidity Trap." BPEA, 2:1998, 137-205.

. 2000. "The End of Stabilization Policy?" In Economic Events, Ideas, and Policies: The 1960s and After, edited by George L. Perry and James Tobin. Brookings. 
Kuttner, Kenneth N. 1994. "Estimating Potential Output as a Latent Variable." Journal of Business and Economic Statistics 12(3): 361-68.

Kuttner, Kenneth N., and Adam S. Posen. 2000. "Inflation, Monetary Transparency, and G3 Exchange Rate Volatility.” Working Paper 00-6. Washington: Institute for International Economics (July).

Kwon, Eunkyung. 1998. "Monetary Policy, Land Prices, and Collateral Effects on Economic Fluctuations: Evidence from Japan.” Unpublished paper. Anyang, Korea: Korea Research Institute for Human Settlements (January).

Lincoln, Edward J. 1998. “Japan's Financial Problems.” BPEA, 2:1998, 347-75. . 2001. Arthritic Japan: The Slow Pace of Economic Reform. Brookings.

Masuda, Yasuyoshi. 2001. "Japan's Economy in the Coming Decade-Towards Rebirth through Creative Destruction." Fuji Research Paper 22. Tokyo: Fuji Research Institute Corporation.

McCallum, Bennett S. 2000. "Theoretical Analysis Regarding a Zero Lower Bound on Nominal Interest Rates." Journal of Money, Credit, and Banking 32(4, part 2): 870-904.

McKinsey Global Institute. 2000. "Why the Japanese Economy Is Not Growing: Micro Barriers to Productivity Growth.” Unpublished paper. Washington: McKinsey \& Company, Inc. (July).

Meltzer, Allan H. 1998. “Time for Japan to Print Money.” AEI Policy Brief. Washington: American Enterprise Institute (August).

____ 1999. "Comments: What More Can the Bank of Japan Do?" Bank of Japan Monetary and Economic Studies 17(3): 189-91.

Mikitani, Ryoichi. 2000. “The Nature of the Japanese Financial Crisis.” In Japan's Financial Crisis and Its Parallels to U.S. Experience, edited by Ryoichi Mikitani and Adam S. Posen. Washington: Institute for International Economics.

Mikitani, Ryoichi, and Adam S. Posen, eds. 2000. Japan's Financial Crisis and Its Parallels to U.S. Experience. Washington: Institute for International Economics.

Mio, Hitoshi. 2001. "Identifying Aggregate Demand and Aggregate Supply Components of Inflation Rate: A Structural VAR Analysis for Japan.” IMES Discussion Paper 2001-E-9. Tokyo: Institute for Monetary and Economic Studies (June).

Morgan, Donald P. 1998. "The Credit Effects of Monetary Policy: Evidence Using Loan Commitments." Journal of Money, Credit, and Banking 30(1): 102-18.

Ogata, Shijuro. 1996. "Financial Markets in Japan.” In National Diversity and Global Capitalism, edited by Suzanne Berger and Ronald P. Dore. Cornell University Press.

Ogawa, Kazuo, and Shin-ichi Kitasaka. 2000. "Bank Lending in Japan: Its Determinants and Macroeconomic Implications." In Crisis and Change in the Japanese Financial System, edited by Takeo Hoshi and Hugh T. Patrick. Amsterdam: Kluwer Academic Publishers. 
Okina, Kunio. 1999a. "Monetary Policy under Zero Inflation: A Response to Criticisms and Questions Regarding Monetary Policy." Bank of Japan Monetary and Economic Studies 17(3): 157-82.

. 1999b. "Monetary Policy under Zero Inflation: Rejoinder." Bank of Japan Monetary and Economic Studies 17(3): 192-97.

Peek, Joe, and Eric S. Rosengren. 1997. "The International Transmission of Financial Shocks: The Case of Japan.” American Economic Review 87(4): 495-505. . 1998. "Japanese Banking Problems: Implications for Southeast Asia." Working Paper 98-7. Federal Reserve Bank of Boston (October).

- 2000. "Collateral Damage: Effects of the Japanese Bank Crisis on Real Activity in the United States." American Economic Review 90(1): 30-45.

—. 2001. "Determinants of the Japan Premium: Actions Speak Louder than Words." Journal of International Economics 53(2): 283-305.

Peek, Joe, Eric S. Rosengren, and Geoffrey M. B. Tootell. 2000. "Identifying the Macroeconomic Effect of Loan Supply Shocks.” Working Paper 00-2. Federal Reserve Bank of Boston (March).

Perri, Fabrizio. 1999. "The Role of Fiscal Policy in Japan: A Quantitative Study.” Working Paper 99-16. New York University, Leonard N. Stern School of Business.

Persson, Torsten, and Guido Tabellini. 2000. Political Economics: Explaining Economic Policy. MIT Press.

Porter, Michael E., Hirotaka Takeuchi, and Mariko Sakakibara. 2000. Can Japan Compete? Basic Books.

Posen, Adam S. 1998. Restoring Japan's Economic Growth. Washington: Institute for International Economics.

1999. "Nothing to Fear But Fear (of Inflation) Itself." International Economics Policy Brief 99-9. Washington: Institute for International Economics.

2000a. "Introduction: Financial Similarities and Monetary Differences." In Japan's Financial Crisis and Its Parallels to U.S. Experience, edited by Ryoichi Mikitani and Adam S. Posen. Washington: Institute for International Economics.

_. 2000b. "The Political Economy of Deflationary Monetary Policy." In Japan's Financial Crisis and Its Parallels to U.S. Experience, edited by Ryoichi Mikitani and Adam S. Posen. Washington: Institute for International Economics.

_. 2001a. "Japan 2001—Decisive Action or Financial Panic.” International Economics Policy Brief 01-4. Washington: Institute for International Economics.

. 2001b. "Unchanging Innovation and Changing Economic Performance in Japan.” Working Paper 01-05. Washington: Institute for International Economics. 
Posen, Adam S., and Debayani Kar. Forthcoming. "Japanese Macroeconomic Policy: Unusual?" Working Paper 02-02. Washington: Institute for International Economics.

Ramaswamy, Ramana, and Christel Rendu. 2000. "Identifying the Shocks: Japan's Economic Performance in the 1990s." In Post-Bubble Blues: How Japan Responded to Asset Price Collapse, edited by Tamim A. Bayoumi and Charles Collyns. Washington: International Monetary Fund.

Rogoff, Kenneth. 1985. "The Optimal Degree of Commitment to an Intermediate Monetary Target." Quarterly Journal of Economics 100(4): 1169-89.

Romer, Christina D. 1993. "The Nation in Depression." Journal of Economic Perspectives 7(2): 19-39.

Roubini, Nouriel. 1996. "Japan's Economic Crisis. Comments for the Panel Discussion on 'Business Practices and Entrepreneurial Spirit in Japan and the United States,", Tokyo, November 12 (www.stern.nyu.edu/ nroubini/ asia/japan.pdf, accessed on August 25, 2001).

Sakakibara, Eisuke. 1999. "Observations on Current Japanese and Asian Economies." In Revitalization of the Japanese Economy and the Future of Asia: Occasional Paper 6. Tokyo: Institute for International Monetary Affairs (June).

Schick, Allen. 1996. "Fiscal Externalities in U.S. and Japanese Budget Policies." Maryland-Tsukuba Papers on U.S.-Japan Relations. University of Maryland (March).

Seidman, Laurence S. 2001. "Reviving Fiscal Policy.” Challenge 44(3): 17-42.

Shimizu, Yoshinori. 2000. "Convoy Regulation, Bank Management, and the Financial Crisis in Japan.” In Japan's Financial Crisis and Its Parallels to U.S. Experience, edited by Ryoichi Mikitani and Adam S. Posen. Washington: Institute for International Economics.

Shirakawa, Masaaki. Forthcoming. "Monetary Policy under the Zero Interest Rate Constraint and Balance Sheet Adjustment." International Finance.

Shiratsuka, Shigenori. 1999. "Measurement Errors in the Japanese Consumer Price Index.” Bank of Japan Monetary and Economic Studies 17(3): 69-102.

Smithers, Andrew. 1999. Government Debt and the Yen. Report 135. London: Smithers \& Co. Ltd. (August).

Steil, Benn. 1995. Illusions of Liberalization: Securities Regulation in Japan and the EC. London: Royal Institute of International Affairs.

Summers, Lawrence H. 1998. "Emerging from Crisis: The Beginnings of a New Asia." Speech presented to the Economic Strategy Institute, Washington, February 11 (www.ustreas.gov/press/releases/pr2217.htm, accessed on August $25,2001)$.

Suzuki, Tomoya. 2001. "The Credit Channel in Japan: Resolving the Supply versus Demand Puzzle." Working Paper in Economics and Econometrics 392. Australian National University. (January). 
Svensson, Lars E. O. 1999. "How Should Monetary Policy Be Conducted in an Era of Price Stability?" Paper presented at the Federal Reserve Bank of Kansas Conference on New Challenges for Monetary Policy, Jackson Hole, Wyoming, August 26-28.

Tavlas, George S. 1998. “Was the Monetarist Tradition Invented?" Journal of Economic Perspectives 12(4): 211-22.

Tax Bureau, Ministry of Finance. 2000. An Outline of Japanese Taxes. Tokyo.

Taylor, John B. 2000. "Low Inflation, Deflation, and Policies for Future Price Stability." Keynote speech at the Ninth International Conference on the Role of Monetary Policy under Low Inflation: Deflationary Shocks and Their Policy Responses, Institute for Monetary and Economic Studies, Bank of Japan, July 3-4.

Ueda, Kazuo. 2000. "Causes of Japan's Banking Problems in the 1990s." In Crisis and Change in the Japanese Financial System, edited by Takeo Hoshi and Hugh T. Patrick. Dordrecht, The Netherlands: Kluwer Academic.

Van den Heuvel, Skander J. 2001. "The Bank Capital Channel of Monetary Transmission." Unpublished paper. University of Pennsylvania (March).

Vogel, Steven K. 1996. Freer Markets, More Rules: Regulatory Reform in Advanced Industrial Countries. Cornell University Press.

Walsh, Carl E. 1997. "Inflation and Central Bank Independence: Is Japan Really an Outlier?" Unpublished paper. Tokyo: Institute for Monetary and Economic Studies (May). 1998. Monetary Theory and Policy. MIT Press.

Watanabe, Katsunori, Takayuki Watanabe, and Tsutomu Watanabe. 2001. "Tax Policy and Consumer Spending: Evidence from Japanese Fiscal Experiments." Journal of International Economics 53(2): 261-81.

Woo, David. 1999. "In Search of 'Capital Crunch': Supply Factors Behind the Credit Slowdown in Japan." IMF Working Paper 99/3. Washington: International Monetary Fund (January).

Woodford, Michael. 2000. "Monetary Policy in a World without Money." International Finance 3(2): 229-60.

Yamaguchi, Yutaka. 1999. "On Recent Monetary Policy.” Speech presented to the Japan Research Institute, Tokyo, October 19 (www.boj.or.jp/en/press/ koen042.htm, accessed on August 25, 2001). 
